\title{
\#USGS
}

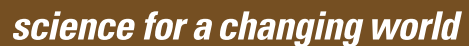

Prepared in cooperation with the Nebraska Game and Parks Commission 8

Hydrogeomorphic Segments and Hydraulic Microhabitats of the Niobrara River Nebraska - With Special Emphasis on the Niobrara National Scenic Ritver

Scientific Investigations

Report 2010-5141

U.S. Department of the Interior U.S. Geological Survey 
Front and back cover. Niobrara River near Norden, Nebraska. Photograph by Jason Alexander, U.S. Geological Survey. 


\section{Hydrogeomorphic Segments and Hydraulic Microhabitats of the Niobrara River, Nebraska-With Special Emphasis on the Niobrara National Scenic River}

By Jason S. Alexander, Ronald B. Zelt, and Nathan J. Schaepe

Prepared in cooperation with the Nebraska Game and Parks Commission

Scientific Investigations Report 2010-5141 


\title{
U.S. Department of the Interior \\ KEN SALAZAR, Secretary \\ U.S. Geological Survey \\ Marcia K. McNutt, Director
}

\section{U.S. Geological Survey, Reston, Virginia: 2010}

\author{
For more information on the USGS — the Federal source for science about the Earth, its natural and living resources, \\ natural hazards, and the environment, visit http://www.usgs.gov or call 1-888-ASK-USGS \\ For an overview of USGS information products, including maps, imagery, and publications, \\ visit http://www.usgs.gov/pubprod \\ To order this and other USGS information products, visit http://store.usgs.gov
}

Any use of trade, product, or firm names is for descriptive purposes only and does not imply endorsement by the U.S. Government.

Although this report is in the public domain, permission must be secured from the individual copyright owners to reproduce any copyrighted materials contained within this report.

Suggested citation:

Alexander, J.S., Zelt, R.B., and Schaepe, N.J., 2010, Hydrogeomorphic and hydraulic habitats of the Niobrara River, Nebraska-with special emphasis on the Niobrara National Scenic River: U.S. Geological Survey Scientific Investigations Report 2010-5141, 62 p. 


\section{Contents}

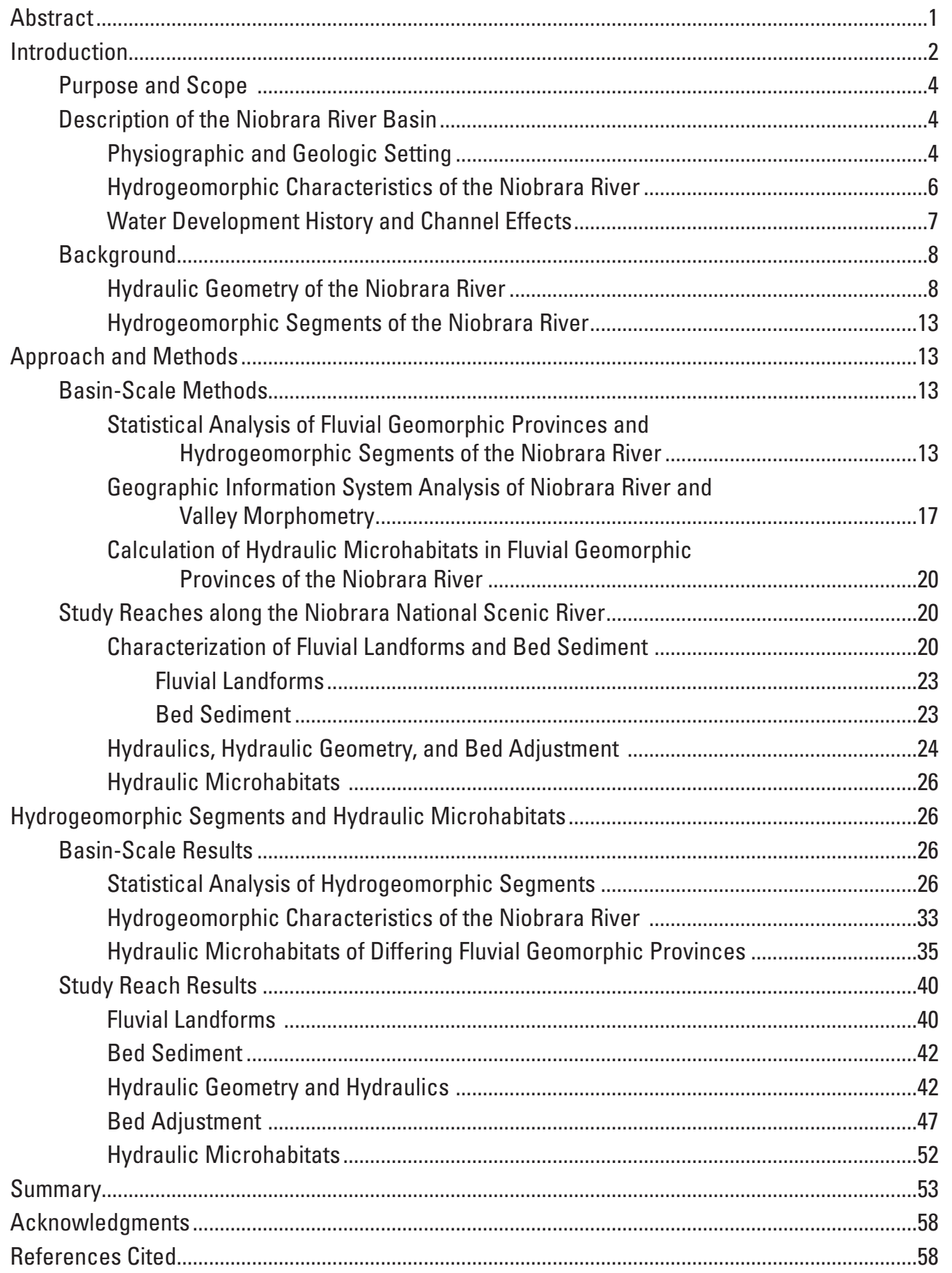




\section{Figures}

1. Map showing location of study area, basin boundary, and National River reaches of the Niobrara River

2. Schematic diagram showing longitudinal profile of the Niobrara River

from the Missouri River upstream to Dunlap Diversion Dam.

3-4. Graphs showing:

3. At-a-station hydraulic geometry relations for selected streamflow-gaging stations on the Niobrara River.

4. Downstream hydraulic geometry relations for the Niobrara River between the streamflow-gaging station near Hay Springs, Nebraska, and the streamflow-gaging station near Verdel, Nebraska

5-6. Maps showing:

5. Extents of Niobrara River fluvial geomorphic provinces, location of main-stem streamflow-gaging stations used in hydraulic microhabitat analysis for each province, and locations of streamflow-gaging stations used to construct longitudinal hydrology curves.

6. Example of digital geographic data sets used to sample Niobrara River channel and valley morphologic characteristics......

7. Graph showing longitudinal hydrology curves of the Niobrara River used for along-stream calculation of unit stream power.

8-9. Maps showing:

8. Location of four reaches within Niobrara National Scenic River where fluvial landforms, bed sediment, and channel hydraulic geometry and hydraulics were studied

9. Layout of channel cross sections at Niobrara River upstream from Crooked Creek near Sparks, Nebraska (425429100235301),

exemplifying four study reaches....

10. Graph showing mean daily discharge of the Niobrara River near Sparks, Nebraska, for the study period October 1, 2007, to November 30, 2008, showing reach-scale discharge measurement time periods

11. Map showing location of study area, basin boundary, and upstream boundaries of hydrogeomorphic segments by fluvial geomorphic province .31

12-14. Graphs showing:

12. Longitudinal distribution of hydrogeomorphic characteristics of the Niobrara River from Dunlap Diversion Dam to the Missouri River....

13. Distribution of available hydraulic microhabitats within four reaches at streamflow-gaging stations of the Niobrara River, Nebraska, for a range of discharges

14. Frequency and cumulative-frequency distributions of the elevation of fluvial landforms in four study reaches of Niobrara National Scenic River, Nebraska

15. Schematic of active fluvial landforms surveyed in study reaches of Niobrara National Scenic River, Nebraska .40

16. Graphs showing bed-sediment grain-size cumulative frequency distributions for four study reaches within Niobrara National Scenic River, Nebraska

17-20. Scatter plots showing:

17. At-a-station hydraulic geometry relations for four study reaches in Niobrara National Scenic River, Nebraska, water years 2008-09 
18. Variation in selected hydraulic parameters over a range of discharges in four study reaches of Niobrara National Scenic River, Nebraska water years 2008-09.

19. Relation of unit stream power to median grain-size diameters sampled over the range of discharges measured in three study reaches of the Niobrara National Scenic River, Nebraska

20. Relation of Froude number to dimensionless relative roughness ratio over the range of discharges measured in three study reaches of the Niobrara National Scenic River, Nebraska

21-22. Graphs showing:

21. Seasonal changes in bed elevation of river channel at cross sections within four study reaches of Niobrara National Scenic River, Nebraska.

22. Distribution of available hydraulic microhabitats within four study reaches of the Niobrara National Scenic River, Nebraska, for a range of discharges

\section{Tables}

1. At-a-station hydraulic geometry relations for eight selected Niobrara River streamflow-gaging stations.

2. Downstream hydraulic geometry relations for the Niobrara River between Hay Springs and Verdel, Nebraska.

3. Segment-scale geomorphic classification system for the Niobrara River, Nebraska

4. Names and abbreviations for hydrogeomorphic variables used in statistical analysis of hydrogeomorphic segments.

5. Streamflow-gaging stations used to construct longitudinal hydrology curves of the Niobrara River from Dunlap Diversion Dam to the Missouri River

6. Typical association between fish species and matrix of depth and velocity combinations defined as hydraulic habitat niches for microhabitat analysis

7. Stations used to index study reaches within the 76-mile Niobrara National Scenic River, Nebraska

8. Hydraulic parameters used to characterize flow and adjustment in Niobrara River study reaches.

9. Number of geomorphic element classes identified by ANOVA multiple comparision analysis

10. Cross-validation results from discriminant analyses of sampling points of the Niobrara River, Nebraska, by geomorphic element class

11. Distribution of classes assigned using discriminant analyses to sampling points within each hydrogeomorphic segment defined by Alexander and others (2009) for the Niobrara River, Nebraska

12. Hydrogeomorphic segments of the Niobrara River between Dunlap Diversion Dam and the Missouri River, Nebraska

13. Physical characteristics of hydrogeomorphic segments of the Niobrara River between Dunlap Diversion Dam and the Missouri River, Nebraska

14. Hydraulic-microhabitat information over a range of flow conditions for reaches at selected Niobrara River gaging stations in differing fluvial geomorphic provinces

15. Fluvial landforms at cross sections within four study reaches of the Niobrara National Scenic River, Nebraska 
16. Grain-size distributions of selected bed-sediment samples from four study reaches in the Niobrara National Scenic River, Nebraska...

17. At-a-station hydraulic geometry relations for four study reaches within Niobrara National Scenic River, Nebraska

18. Summary of channel discharge, geometry, and hydraulic parameters calculated from measurements made in 2008 at four study reaches in Niobrara National Scenic River, Nebraska.

19. Hydraulic microhabitat distribution over a range of streamflow conditions for four study reaches in Niobrara National Scenic River, Nebraska

\section{Conversion Factors and Datums}

Inch/Pound to SI

\begin{tabular}{lcl}
\hline Multiply & By & To obtain \\
\hline inch (in.) & 2.54 & centimeter $(\mathrm{cm})$ \\
foot $(\mathrm{ft})$ & 0.3048 & meter $(\mathrm{m})$ \\
mile $(\mathrm{mi})$ & 1.609 & kilometer $(\mathrm{km})$ \\
square foot $\left(\mathrm{ft}^{2}\right)$ & 0.0929 & square meter $\left(\mathrm{m}^{2}\right)$ \\
square mile $\left(\mathrm{mi}^{2}\right)$ & 2.590 & square kilometer $\left(\mathrm{km}^{2}\right)$ \\
cubic foot $\left(\mathrm{ft}^{3}\right)$ & 28.32 & cubic decimeter $\left(\mathrm{dm}^{3}\right)$ \\
cubic foot $\left(\mathrm{ft}^{3}\right)$ & 0.02832 & cubic meter $\left(\mathrm{m}^{3}\right)$ \\
foot per second $(\mathrm{ft} / \mathrm{s})$ & 0.3048 & meter per second $(\mathrm{m} / \mathrm{s})$ \\
cubic foot per second $\left(\mathrm{ft}^{3} / \mathrm{s}\right)$ & 0.02832 & cubic meter per second $\left(\mathrm{m}^{3} / \mathrm{s}\right)$ \\
pound-force per square foot $\left(\mathrm{lb} / \mathrm{ft}^{2}\right)$ & 47.89 & newton per square meter $\left(\mathrm{N} / \mathrm{m}^{2}\right)$ \\
pound per foot-second $(\mathrm{lb} / \mathrm{ft}-\mathrm{s})$ & 14.59 & newton per meter-second $(\mathrm{N} / \mathrm{m}-\mathrm{s})$ \\
\hline SI to Inch/Pound & & \\
\hline Multiply & & \\
\hline millimeter $(\mathrm{mm})$ & $\mathbf{B y}$ & To obtain \\
meter $(\mathrm{m})$ & 0.03937 & inch $($ in. $)$ \\
kilometer $(\mathrm{km})$ & 3.281 & foot $(\mathrm{ft})$ \\
square meter $\left(\mathrm{m}^{2}\right)$ & 0.6212 & mile $(\mathrm{mi})$ \\
square kilometer $\left(\mathrm{km}{ }^{2}\right)$ & 10.76 & square foot $\left(\mathrm{ft}^{2}\right)$ \\
cubic meter $\left(\mathrm{m}^{3}\right)$ & 0.3861 & square mile $\left(\mathrm{mi} \mathrm{i}^{2}\right)$ \\
cubic meter $\left(\mathrm{m}^{3}\right)$ & 264.2 & gallon $(\mathrm{gal})$ \\
meter per second $(\mathrm{m} / \mathrm{s})$ & 0.0002642 & million gallons $(\mathrm{Mgal})$ \\
cubic meter per second $\left(\mathrm{m}^{3} / \mathrm{s}\right)$ & 3.281 & foot per second $(\mathrm{ft} / \mathrm{s})$ \\
newton per square meter $\left(\mathrm{N} / \mathrm{m}^{2}\right)$ & 35.31 & cubic feet per second $\left(\mathrm{ft}^{3} / \mathrm{s}\right)$ \\
newton per meter-second $(\mathrm{N} / \mathrm{m}-\mathrm{s})$ & 0.1622 & pound-force per square foot $\left(\mathrm{lb} / \mathrm{ft}^{2}\right)$ \\
\hline & 0.0685 & pound per foot-second $(\mathrm{lb} / \mathrm{ft}-\mathrm{s})$ \\
\hline
\end{tabular}

Vertical coordinate information is referenced to the North American Vertical Datum of 1988 (NAVD 88).

Horizontal coordinate information is referenced to the North American Datum of 1983 (NAD 83).

Water year is defined as the 12-month period October 1 through September 30.

The water year is designated by the calendar year in which it ends. 


\title{
Hydrogeomorphic Segments and Hydraulic Microhabitats of the Niobrara River, Nebraska - With Special Emphasis on the Niobrara National Scenic River
}

\author{
By Jason S. Alexander, Ronald B. Zelt, and Nathan J. Schaepe
}

\section{Abstract}

The Niobrara River is an ecologically and economically important resource in Nebraska. The Nebraska Department of Natural Resources' recent designation of the hydraulically connected surface- and groundwater resources of the Niobrara River Basin as "fully appropriated" has emphasized the importance of understanding linkages between the physical and ecological dynamics of the Niobrara River so it can be sustainably managed. In cooperation with the Nebraska Game and Parks Commission, the U.S. Geological Survey investigated the hydrogeomorphic and hydraulic attributes of the Niobrara River in northern Nebraska. This report presents the results of an analysis of hydrogeomorphic segments and hydraulic microhabitats of the Niobrara River and its valley for the approximately 330-mile reach from Dunlap Diversion Dam to its confluence with the Missouri River. Two spatial scales were used to examine and quantify the hydrogeomorphic segments and hydraulic microhabitats of the Niobrara River: a basin scale and a reach scale.

At the basin scale, digital spatial data and hydrologic data were analyzed to (1) test for differences between 36 previously determined longitudinal hydrogeomorphic segments; (2) quantitatively describe the hydrogeomorphic characteristics of the river and its valley; and (3) evaluate differences in hydraulic microhabitat over a range of flow regimes among three fluvial geomorphic provinces.

The statistical analysis of hydrogeomorphic segments resulted in reclassification rates of 3 to 28 percent of the segments for the four descriptive geomorphic elements. The reassignment of classes by discriminant analysis resulted in a reduction from 36 to 25 total hydrogeomorphic segments because several adjoining segments shared the same ultimate class assignments. Virtually all of the segment mergers were in the Canyons and Restricted Bottoms (CRB) fluvial geomorphic province. The most frequent classes among hydrogeomorphic segments, and the dominant classes per unit length of river, are: a width-restricted valley confinement condition, sinuous-planview pattern, irregular channel width, and an alternate bar configuration.
The Niobrara River in the study area flows through a diversity of fluvial geomorphic settings in its traverse across northern Nebraska. In the Meandering Bottoms (MB) fluvial geomorphic province, river discharge magnitudes are low, and the valley exerts little control on the channel-planview pattern. Within the CRB province, the river flows over a diversity of geologic formations, and the valley and river narrow and expand in approximate synchronicity. In the Braided Bottoms (BB) fluvial geomorphic province, the river primarily flows over Cretaceous Pierre Shale, the valley and channel are persistently wide, and the channel slope is generally uniform. The existence of vegetated islands and consequent multithread channel environments, indicated by a higher braided index, mostly coincided with reaches having gentler slopes and less unit stream power. Longitudinal hydrology curves indicate that the flow of the Niobrara River likely is dominated by groundwater as far downstream as Norden. Unit stream power values in the study area vary between 0 and almost 2 pounds per foot per second. Within the MB province, unit stream power steadily increases as the Niobrara gains discharge from groundwater inflow, and the channel slope steepens. The combination of steep slopes, a constrained channel width, and persistent flow within the CRB province results in unit stream power values that are between three and five times greater than those in less confined segments with comparable or greater discharges. With the exception of hydrogeomorphic segment 3, which is affected by Spencer Dam, unit stream power values in the BB province are generally uniform. Channel sinuosity values in the study area varied generally between 1 and 2.5, but with locally higher values measured in the MB province and at the entrenched bedrock meanders of hydrogeomorphic segment 18 in the CRB province.

The differences in channel morphology and hydraulic geometries between fluvial geomorphic provinces are evident in the types, relative abundance, and response of hydraulic microhabitats to changing discharges. The four gaging stations chosen for hydraulic microhabitat analysis are distributed among three different fluvial geomorphic provinces. In the MB province, the smaller channel and lower discharges resulted in the dominance of shallow and intermediate-depth hydraulic environments with the vast majority of hydraulic 
microhabitat restricted to shallow categories even during upper-decile discharges. In the CRB province, intermediatedepth hydraulic conditions, particularly intermediate-swift, dominate over all ranges of discharge. Hydraulic microhabitat conditions were most diverse in the BB province, with most hydraulic microhabitat categories present over the entire range of discharges analyzed. The calculated differences in hydraulic microhabitat distributions, abundance, and adjustments between streamflow-gaging stations were the result of differences in physical structure of the channel and subsequent channel hydraulic geometry.

At the reach scale, field measurements made in water years 2008 and 2009 in four study reaches within the Scenic Reach were used to (1) characterize the elevation and geomorphic processes associated with fluvial landforms, (2) build hydraulic geometry relations, (3) examine flow hydraulics over a range of discharges, and (4) examine the types and responses of hydraulic microhabitats to a range of flow magnitudes. Four landform groups were identified and named in order of increasing elevation: low flood plains, intermediate flood plains, low terraces, and high terraces. The terraces were poorly characterized because the surveys did not extend across the full width of the alluvial valley bottom. The two lowest fluvial landforms are likely active in the modern hydroclimatic regime. Sediment samples obtained in the study reaches indicate that the primary bed material in the active channel ranged in size from coarse silt to coarse sand. Grain-size distributions from samples also indicate that the bed of the Niobrara River among the study reaches coarsens and has increasing grainsize variability in the downstream direction.

Values of at-a-station hydraulic geometry exponents indicate that the Niobrara River in the study reaches adjusts its geometry to changing discharges primarily through increases in flow depth and velocity. Relations at one cross section indicated that, at least locally, changes in width were also an important channel adjustment mechanism. Hydraulic behavior over the range of flows measured was not consistent among all study reaches, but two general modes of hydraulic behavior were observed in the reaches with substantial coverage of the bed by fine sediment. At the Sunny Brook and Muleshoe study reaches, average boundary-shear stress remained approximately constant, and hydraulic resistance decreased, for discharges below 900 cubic feet per second $\left(\mathrm{ft}^{3} / \mathrm{s}\right)$. Above $900 \mathrm{ft}^{3} / \mathrm{s}$, average boundary shear stress and hydraulic resistance both increased. The Rock Barn study reach did not exhibit the same two-mode hydraulic behavior observed at the Sunny Brook and Muleshoe reaches. The coincident increase in boundary shear stress above $900 \mathrm{ft}^{3} / \mathrm{s}$ observed at the Sunny Brook and Muleshoe study reaches represents a potential hydraulic threshold above which bedload transport rates were likely to increase markedly. No consistent bed-adjustment pattern (scour or fill) was identified in the study reaches over the range of flows or over the measurement season.

Analysis of hydraulic microhabitats over the range of discharges measured at the study reaches indicates that some percentage of most habitat niche categories was available for at least one discharge condition, but the majority of hydraulic habitat available was within the intermediate-swift and deepswift habitat niche categories. Deep-swift conditions dominated nearly all study reaches under all measured discharge conditions. Slight differences in habitat distributions were observed between the study reaches with substantial coverage of the bed by fine sediment-Sunny Brook, Muleshoe, and Rock Barn - and the bedrock-dominated reach, Crooked Creek. Although the four study reaches occupy three different hydrogeomorphic segments, the types, relative abundance, and response of hydraulic microhabitat niche distributions to changing discharge conditions generally were similar among all reaches.

\section{Introduction}

The Niobrara River of Nebraska is an ecologically and economically important resource, renowned for its biological diversity, paleontological richness, and abundant recreational opportunities (Johnsgard, 2001, 2007). The steady, dependable flow of the Niobrara River makes it an important source of irrigation water for local agriculture, which is the foundation of the regional economy. The geographic setting and physiography of the Niobrara River Valley facilitate the convergence, hybridization, and survival of at least five terrestrial ecosystem community types within a relatively narrow corridor (Johnsgard, 2001). This unique quality was recognized by the United States Congress in 1991 when a portion of the river was granted Federal protection under the Wild and Scenic Rivers Act of 1968 (Roeder, 2004). The 76-mile (mi) reach of river is now recognized as the Niobrara National Scenic River (hereinafter referred to as the "Scenic Reach") near Valentine, Nebr. (fig. 1) and is cooperatively managed by a consortium of private landowners, and State and Federal agencies. The 28-mile reach of the Niobrara River upstream from the Missouri River (hereinafter named the "Recreational Reach") are protected within the Missouri National Recreational River (fig. 1).

The Nebraska Department of Natural Resources' (NDNR) recent designation of the hydraulically connected surface- and groundwater resources of the Niobrara River Basin as "fully appropriated" (Nebraska Department of Natural Resources, 2007) has emphasized the importance of understanding linkages between the physical and ecological dynamics of the Niobrara River so it can be sustainably managed. Among the key questions identified for study by an interagency working group are:

1. What flow regime is needed to maintain the present quantity and diversity of stream physical habitats that distinguish the Niobrara as a healthy ecosystem?

2. What frequency, duration, and timing of infrequent hydrologic disturbances (floods, droughts, ice jams) are needed 

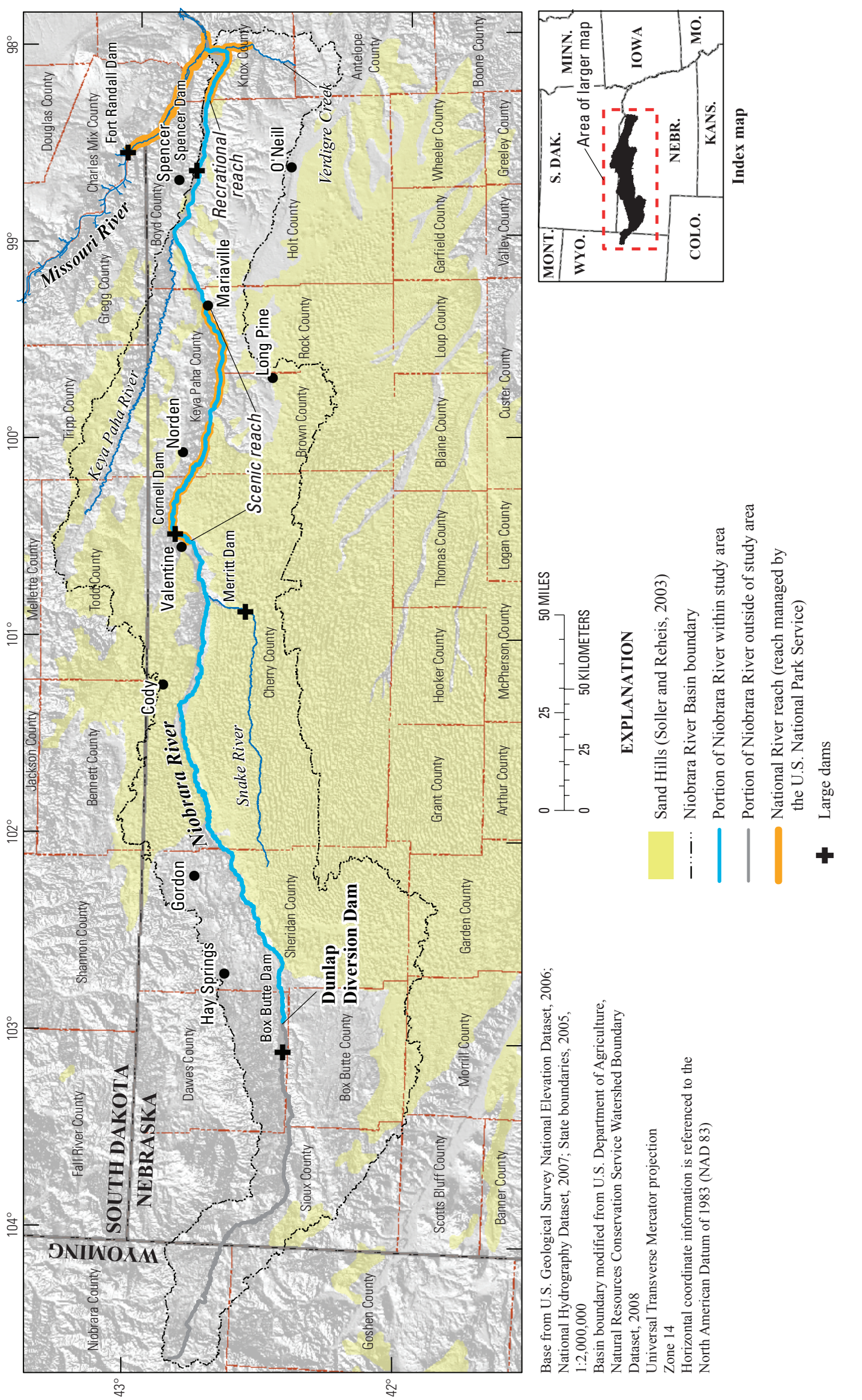

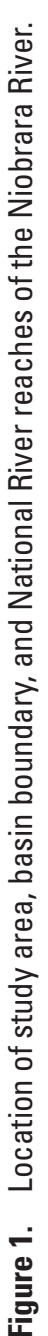

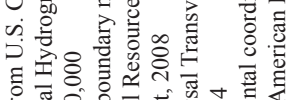

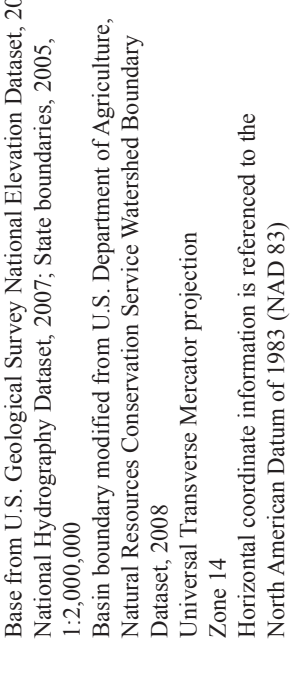


to maintain a dynamic equilibrium of fluvial geomorphic processes to sustain the present channel character?

To begin to address either question, an understanding of the Niobrara River's present channel character and associated diversity of stream physical attributes is necessary. Additionally, an investigation of Niobrara River channel hydraulics may assist in understanding channel adjustment and maintenance processes, as well as flood plain connectivity. Numerous scientific studies have investigated the physical and hydraulic attributes of the Niobrara River along isolated reaches (Colby and others, 1953; Colby and Hembree, 1955; Hearty, 1978; Buchanan, 1981; Swinehart and others, 1985; Voorhies, 1987; Cole, 1996; Skelly, 1998; Etheridge and others, 1999); however, none have placed these characteristics within a spectrum of fluvial settings at the basin scale. Such a study may provide the physical context for water-management strategies and serve as a framework for integrated physical and biological investigations.

In cooperation with the Nebraska Game and Parks Commission (NGPC), the U.S. Geological Survey (USGS) investigated the hydrogeomorphic and hydraulic attributes of the 330-mi reach of the Niobrara River from Dunlap Diversion Dam in western Nebraska (fig. 1) to the confluence with the Missouri River in northeastern Nebraska.

\section{Purpose and Scope}

The purpose of this report is to present the results of an analysis of hydrogeomorphic segments and hydraulic microhabitats of the Niobrara River and its valley for the approximately 330-mi reach from Dunlap Diversion Dam to its confluence with the Missouri River (hereinafter referred to as the "study area") (fig. 1). Two spatial scales were used to examine and quantify the hydrogeomorphic segments and hydraulic microhabitats of the Niobrara River: a basin scale and a reach scale. At the basin scale, digital spatial data and hydrologic data were analyzed to (1) test for differences between 36 previously determined longitudinal hydrogeomorphic segments; (2) quantitatively describe the hydrogeomorphic characteristics of the river and its valley; and (3) evaluate differences in hydraulic microhabitat over a range of flow regimes among three fluvial geomorphic provinces. The periods of record examined at each streamflow-gaging station were variable, and spanned water years 1950 through 2008 . At streamflow-gaging stations downstream from the confluence of the Snake River, only the period of record available after water year 1963 was used because the operations of a large dam began in water year 1964. At the reach scale, field measurements made in water years 2008 and 2009 in study reaches within the Scenic Reach were used to (1) characterize the elevation and geomorphic processes associated with fluvial landforms, (2) build hydraulic geometry relations, (3) examine flow hydraulics over a range of discharges, and (4) examine the types and responses of hydraulic microhabitats to a range of flow magnitudes.

\section{Description of the Niobrara River Basin}

Geologic formations described in subsequent sections of this report have been compiled from various resources for the purposes describing variation in physical characteristics of the Niobrara River Basin. Some of the geologic nomenclatures described below are from the University of Nebraska-Lincoln. Where appropriate, the sources of the geologic information have been cited.

\section{Physiographic and Geologic Setting}

The Niobrara River originates in the tablelands of east-central Wyoming and flows eastward approximately $560 \mathrm{mi}$, mainly through northern Nebraska, before reaching its confluence with the Missouri River in northeastern Nebraska (fig. 1). The Niobrara River Basin drains about 13,480 square miles $\left(\mathrm{mi}^{2}\right)$, including parts of Nebraska, South Dakota, and Wyoming. The headwaters of the Niobrara River lie at an elevation of approximately 5,500 feet (ft), and the descent of the river is approximately 4,280 ft. Average annual rainfall increases from approximately 14 inches in the west to 24 inches in the east (Dugan and Zelt, 2000). A large part of the basin lies within the Nebraska Sand Hills (sandhills), a vast region of vegetation-stabilized sand dunes (fig.1). The high infiltration capacity of the sandhills virtually eliminates direct surface runoff from precipitation, and, instead, water is fed to adjacent streams through groundwater seepage (Bentall and Shaffer, 1979). West of Valentine, Nebr., groundwater is the primary source of flow in the Niobrara River. The discharge of the river is steady and persistent, and overbank flooding is uncommon, except during winter ice jams (Missouri River Basin Inter-Agency Committee, 1967; Shaffer, 1975; Voorhies, 1987). The steady nature of the flow regime of the Niobrara River is less apparent downstream from Valentine, because of increasing volumes of precipitation, increases in storm runoff from small tributaries, and changes in soil infiltration rates near the eastern margin of the sandhills (Shaffer, 1975; Hearty, 1978; Istanbulluoglu, 2009).

The Niobrara River in the study area flows alternately through wide alluvial valleys, valleys bound by escarpments, and narrow sinuous canyons (University of NebraskaLincoln, Conservation and Survey Division, 1986; Alexander and others, 2009). For much of its length, the valley of the Niobrara River is incised into sedimentary bedrock of late Cretaceous and Tertiary ages (fig. 2), most of which is gently sloping from east to west (Hearty, 1978; Swinehart and others 1985; Burchett, 1986; Voorhies, 1987). Swinehart and others (1985) divided the Tertiary-age sediments into two major packages: an older, generally homogenous package of fine-grained volcaniclastic rocks deposited by wind, and a younger, coarser package composed primarily of alluvial deposits. The older package is composed primarily of the White River Group and Arikaree Group, and the younger package is composed primarily of the Ogallala Group. The 


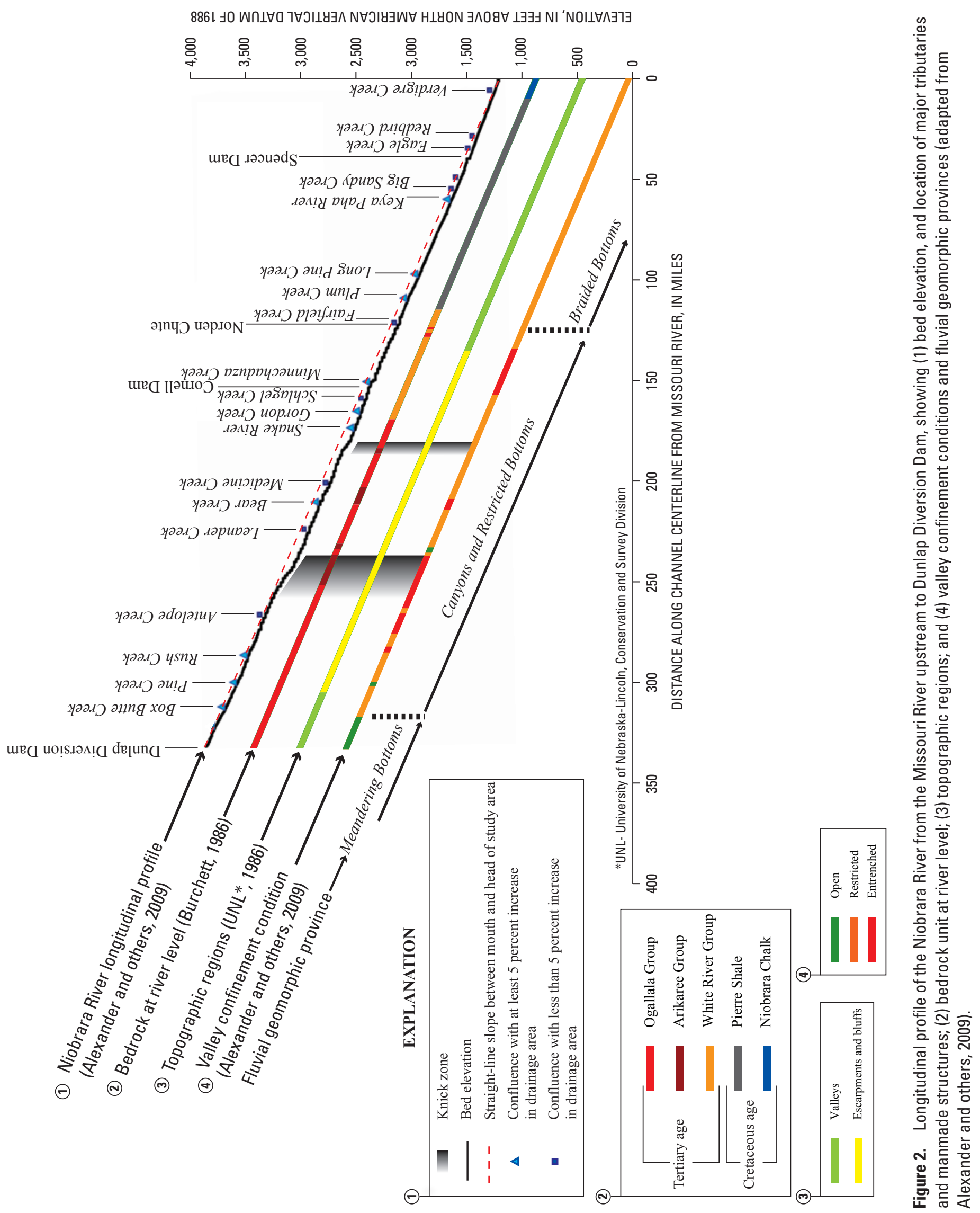


dramatic bluffs of the Scenic Reach are composed of the resistant Rosebud Formation of the White River Group overlain by the less resistant Valentine unit and highly resistant Cap Rock Member of the Ash Hollow Formation of the Ogallala Group (Voorhies, 1987). East of Norden, the Niobrara flows over Cretaceous-age rocks, including the Pierre Shale and the Niobrara Chalk. In a previous study, convexities in the longitudinal profile of the river, along with deeply entrenched and restricted reaches, indicated that bedrock exerted a significant control on the characteristics of channel form, particularly the channel slope (Alexander and others, 2009). The slope of the Niobrara River becomes more uniform, and the river channel shifts from a narrow sinuous pattern to a wide, braided pattern downstream from where it crosses the Tertiary-Cretaceous rock contact. Upstream from the contact, changes in river slope are located near changes in bedrock type at river level as well as bedrock structural features (Swinehart and others, 1985; Alexander and others, 2009).

\section{Hydrogeomorphic Characteristics of the Niobrara River}

As a river traverses a landscape, it gathers both water and sediment, and adjusts its geometry (width, depth, and slope) to efficiently transport the sediment load with the given flow regime and under the physical constraints imposed by the landscape itself, such as geology and vegetation (Leopold and Maddock, 1953; Wolman and Gerson, 1978; Huang and Nanson, 2000). The term "hydrogeomorphic" is used herein to encompass the host of form characteristics and processes associated with the interactions of water (hydro) and the landscape through which it flows (geomorphic). These characteristics and processes include the caliber and quantity of the sediment load, the geometric characteristics of the river channel; the composition of the river bed, banks, and fluvial landforms (bars, flood plains, and terraces); and river hydrology and hydraulics (flow regime).

Measurements of sediment discharge and samples of bed material indicate that the sediment load of the Niobrara River is well-sorted, almost entirely finer than 1.0 millimeter (mm; 0.03937 in.), and does not fine dramatically in the downstream direction (Colby and others, 1953; Colby and Hembree, 1955; Buchanan, 1981). Colby and Hembree (1955) measured sediment discharge near Cody, Nebr. (fig. 1). They reported a median bed-material size between 0.25 and $0.30 \mathrm{~mm}$ and estimated that between 40 and 60 percent of the sediment discharge of the Niobrara River was carried as bedload. Colby and others (1953) reported nearly identical results for bedmaterial grain sizes and ratios of bedload to total sediment load at the Niobrara River near Valentine, Nebr. Buchanan (1981) sampled bed material along several transects downstream from Norden and reported median grain sizes ranging from 0.2 to $0.3 \mathrm{~mm}$.

The Niobrara River in the study area has several reaches where the river banks are alluvial, but the river is flowing directly over bedrock, indicating that the relative sediment transporting capacity of the river is, in some places, much higher than the supply being delivered from upstream (Howard, 1987, 1998). At two of these reaches, one near Cody, Nebr., and the other near Norden, the river has incised bedrock chutes with pronounced bedrock shelves for banks (fig. 1); both sites were previously used by the USGS as streamflow-gaging stations because of their cross-sectional and hydraulic control stability. Immediately upstream from Dunlap Diversion Dam, the Niobrara River has alluvial banks, but flows over bedrock, locally derived angular gravels, and sparse sand dunes (Randle, 2002). The sand acquired from bank erosion downstream from Box Butte Dam accumulates at Dunlap Diversion Dam and must occasionally be dredged (Randle, 2002), potentially indicating that the bed of the Niobrara River downstream from Dunlap Diversion Dam also may be sediment starved, and flowing over bedrock for some distance. Within the Scenic Reach, the river banks are alluvial, but the bed is a mix of bedrock and sand dunes (Colby and others, 1953). Immediately downstream from Norden, Bureau of Reclamation bore-hole logs indicate that the alluvium is as thick as $60 \mathrm{ft}$ (Buchanan, 1981). The steadier channel slope and deeper alluvium downstream from Norden suggest the transporting capacity of the river is likely in dynamic equilibrium with its upstream sediment supply and geologic controls (Alexander and others, 2009).

Previous geomorphic investigations of the Niobrara River bottomlands generally have been focused within the Scenic Reach. Hearty (1978) investigated the reach of the Niobrara valley between Cornell Dam and Norden and divided the area into six geomorphic regions: dune-mantled terraces south of the river; rolling hills and depressions of low relief on the tablelands north of the river; deeply dissected canyons draining the tablelands north of the river; low terraces adjacent to the river; a steep, south cutbank of the river; and the river and its modern flood plain. Hearty suggested that mass-wasting, mainly seepage-induced landsliding on the south side of the river, was the dominant channel-form process within the confined sections of the Scenic Reach. The landslides ranged in age from 9 months to 30 years, and intermittently delivered between 130 and 900 cubic meters $\left(\mathrm{m}^{3}\right)$ of sediment, as well as large woody debris, to the river bottom. Hearty also noted that the steep dissected canyons north of the river had narrow, v-shaped channels, and were prone to severe flash flooding, delivering their sediment episodically during summer thunderstorms.

Buchanan (1981) investigated the dynamics of the wide, braided section of the Scenic Reach between Norden and Mariaville, Nebr. (fig. 1) and presented four geomorphic elements that define the wide, braided reaches of the Niobrara River: channels, bars, sand flats, and vegetated islands. Buchanan described the seasonal variation in Niobrara River channel planform within the wide, braided reaches. During high flows, the channel consisted mainly of a thalweg, which meandered through extensive, emergent sand flats; as the season persisted and flows decreased, the thalweg was 
aggraded by low-amplitude sand waves. The sand flats were flooded, and the river eventually occupied the entire active channel within the flood plain. High flows were usually coincident with ice breakup in the late winter or early spring.

Channel flood plain connectivity of the Niobrara River is not well-documented. Flooding on the Niobrara is mainly associated with winter ice jams, and has resulted in occasional damage to bridges and roadways (Missouri Basin InterAgency Committee, 1967). Hearty (1978) mapped the alluvial landforms of the river bottom within the Scenic Reach and classified alluvial terraces into three groups: those between 8.2 and $29.5 \mathrm{ft}(2.5$ and $9 \mathrm{~m})$, those between 49.2 and $164 \mathrm{ft}$ $(15$ and $50 \mathrm{~m}$ ), and those between 197 and $312 \mathrm{ft}$ (60 and $95 \mathrm{~m}$ ) higher than the modern flood plain. The elevation of the modern flood plain above any reference discharge was not reported. Hearty also investigated terrace stratigraphy and reported that numerous soil horizons buried by crossstratified river alluvium indicated that deposition was rapid and episodic, a finding that is consistent with occasional, ice-induced flooding. Likewise, Buchanan (1981) reported that river stage near Norden was up to $3 \mathrm{ft}$ higher for discharges during heavy ice cover than those without ice cover.

\section{Water Development History and Channel Effects}

The Niobrara River and its tributaries have numerous dams and diversions (Alexander and others, 2009). Two of these dams, Box Butte Dam and Merritt Dam, have altered the hydrology of the Niobrara River by diverting water for irrigation (fig. 1). Box Butte Dam, located on the main stem of the Niobrara River approximately 10 miles upstream from Dunlap Diversion Dam, began storing water in 1945 for the Mirage Flats Irrigation Project (Shaffer, 1975). Box Butte Reservoir releases water for diversion into a delivery canal at Dunlap Diversion Dam. Below Dunlap Diversion Dam, average daily flows are reduced by 90 percent relative to inflow to Box Butte Reservoir, but the river regains significant flow in the miles downstream from the diversion, mainly from groundwater seepage (Bentall and Shaffer, 1979). Merritt Dam, located along the Snake River, a large tributary to the Niobrara River, began storing water for the Ainsworth Irrigation Project in 1964. Storage in the reservoir behind Merritt Dam reduced the base flows (flows exceeded 99 percent of the time) of the Snake River below the dam by 95 percent but had less effect on the discharge of the peak flows (Shaffer, 1975). Buchanan (1981) reported a reduction of 15 percent in mean annual flows since 1964 at the Niobrara River streamflow-gaging station near Norden (station number 06462000). He also reported reductions of nearly 19 and 28 percent in the mean annual monthly maximum (March) discharge and mean annual monthly minimum (August) discharge, respectively, at the Norden gage.

The main stem of the Niobrara River also has had two hydroelectric dams: Cornell Dam, near Valentine, Nebr., and Spencer Dam, near Spencer, Nebr.. Cornell Dam was constructed in 1915, but has been inactive since 1986. Since that time, the holding basin behind the dam has completely filled in with sediment, and the river likely passes the entire upstream sediment load. Spencer Dam was constructed in 1927 and remains active as a run-of-river power-generating facility. The holding basin behind Spencer Dam filled with sediment within a few years after dam construction (Nebraska Game and Parks Commission, 1980), and sediment now is flushed twice annually to evacuate storage volume. Thus, the daily operations of Spencer Dam have little effect on the downstream hydrology, but the dam acts as a seasonal barrier to the upstream sediment supply (Gutzmer and others, 1996). The seasonal disruption of sediment supply has altered the channel form of the Niobrara downstream to at least Eagle Creek, the first tributary downstream from the dam (Cole, 1996; Alexander and others, 2009).

Investigations of channel change associated with natural and human-induced alterations to flow and sediment regimes of the Niobrara River have been focused in reaches downstream from Norden, Nebr. Buchanan (1981) documented changes in channel morphology associated with natural and human-forced shifts in hydrology and used aerial photographs to identify two episodes of channel narrowing. The first narrowing episode occurred during the prolonged drought of the 1930s and was followed by a subsequent period of widening; the second narrowing episode occurred after closure of Merritt Dam on the Snake River. Changes in channel width at 16 transects indicated that the river width decreased by a median of 19 percent after closure of Merritt Dam. The magnitude of narrowing was greatest in the widest reaches, and no measureable changes in channel width were observed at naturally constricted reaches of the river. The process of narrowing involved the formation of vegetated islands, sedimentation of side channels, and attachment of vegetated islands and bars to the flood plain (Buchanan, 1981).

The construction of two multipurpose flood control dams in the 1950s on the Missouri River upstream and downstream from the mouth of the Niobrara River resulted in substantial changes to the morphology and channel dynamics of the last 12 miles of the Niobrara River channel (Etheridge and others, 1999). The reduction of flood magnitudes on the Missouri River upstream from the Niobrara River mouth and creation of a reservoir downstream from the Niobrara River mouth decreased both the load and sediment-transport capacity of the Missouri River, and the sediment load of the Niobrara River began building a delta. Between 1950 and 1996, the bed of the Niobrara River at the Missouri River confluence rose by as much as $7.5 \mathrm{ft}$ (2.3 m) (Bristow and others, 1999). Between 1950 and 1989, the dominant channel adjustment was bed aggradation and channel narrowing by island and flood plain deposition. Beginning in 1989, episodes of channel avulsion, initiated primarily by ice or debris jams, have created a network of distributary channels, separated by vast, vegetated islands (Etheridge and others, 1999). 


\section{Background}

The geometry of an alluvial river channel is affected by several physical stressors, including the nature of the flow regime, geologic setting, caliber and quantity of the sediment supply, and valley pattern and confinement, and by biological stressors such as vegetation growth and beaver activity (Leopold and Maddock, 1953; Hey and Thorne, 1986; Parker and others, 2007; Shafroth and others, 2010). These stressors interact in time and space to determine the configuration and dynamics of the river bed, channel hydraulics, and the chemistry of its waters, which subsequently interact to create the natural physical habitat attributes of any particular patch of river space (Poff and Ward, 1990; Power and others, 1995; Doyle and others, 2005). Human or natural alterations to the flow regime, surrounding landscape, or channel geometry may interact to produce alterations in a river's physical habitat attributes that are detrimental to ecosystem function (Junk and others, 1989; Poff and others, 1997). An investigation and description of the broad physical attributes of a river system and the dynamics of hydraulic adjustment may act as an organizing framework for sustainable management of a river basin by identifying the range of different fluvial settings and their associated (or potential) physical processes (Kondolf and Downs, 1996).

\section{Hydraulic Geometry of the Niobrara River}

Hydraulic geometry relations use the hydrographer's streamflow measurement notes from individual gaging stations (at-a-station geometry) to relate wetted-channel geometry and water velocity to river discharge. The relations use a series of empirical models in the form of power laws as presented by Leopold and Maddock (1953):

$$
\begin{gathered}
w=a \mathrm{Q}^{b} \\
d=c \mathrm{Q}^{f} \\
v=k \mathrm{Q}^{m}
\end{gathered}
$$

The variables $w, d$, and $v$ are wetted-channel top width, mean depth, and mean velocity of the cross section, respectively; $a$, $c, k, b, f$, and $m$ are numerical constants; and $Q$ is a reference discharge. The product of $w, d$, and $v$ are equal to $Q$, an equation known to hydrologists as "continuity" because, over short distances, the discharge of a river must be the same, even if the geometry of the river changes. Therefore, by substitution, we obtain:

$$
\mathrm{Q}=a \mathrm{Q}^{b} * c \mathrm{Q}^{f} * k \mathrm{Q}^{m}
$$

By continuity, the exponents of equations 1-3 must sum to unity, and the products of the coefficients of equations 1-3 must be unity.

$$
\begin{aligned}
& b+f+m=1 \\
& a * c * k=1
\end{aligned}
$$

The magnitude of the exponent for each equation describes the slope of a best-fit (least-squares regression) line through a logarithmically scaled scatter plot of the relation, with discharge as the independent variable. The magnitude of the slope is a measure of the rate of adjustment of each variable at a cross section over a range of discharges.

Hydraulic geometry relations are commonly developed at two scales: a local scale, referred to as "at-a-station," and a basin scale referred to as "downstream" hydraulic geometry. At-a-station hydraulic geometry relations describe how a channel at a particular location within a basin adjusts to temporally changing discharges, and downstream-hydraulic geometry relations describe how the river channel adjusts in the downstream direction to increases in basin area and discharge. In the United States for rivers of the semi-arid Southwest and Great Plains, Leopold and Maddock (1953) reported at-a-station averages of $0.26,0.40$, and 0.34 and downstream averages of $0.5,0.4$, and 0.1 for exponents $b, f$, and $m$ (width, depth, and velocity), respectively; these values, however, have been shown to be highly variable depending on regional climate and physiography (Knighton, 1974; Park, 1977).

In the previous study by Alexander and others (2009) the nature of channel adjustment in the Niobrara River Basin from Dunlap Diversion Dam to the Missouri River was investigated using hydraulic-geometry relations. Only the records from water years 1964 through 2008 were used, except those stations near Hay Springs and Cody, which are upstream from the Snake River confluence, and are therefore not affected by operations at Merritt Dam. At-a-station exponents averaged $0.14,0.40$, and 0.45 for $b, f$, and $m$, respectively; however, the width exponent $b$ exhibited a range from 0.00 to 0.32 (fig. 3 ; table 1). The variability of the at-a-station width exponent at two gaging stations located one-half mile apart along the Niobrara accounted for most of the range of exponent variability because one gage was located at a bridge across an unrestricted section and the other was located near a natural river constriction. Downstream hydraulic geometry exponents for the median-annual discharge of the Niobrara River were 0.53, 0.26 , and 0.21 for $b, f$, and $m$, respectively (fig. 4; table 2). Although the downstream width exponent, $b$, generally conforms to the widely reported value of 0.5 , it was suspected that the wide range in the at-a-station width exponent, $b$, in particular the very low values at bedrock constrictions, skewed the downstream hydraulic geometry width exponents low. 

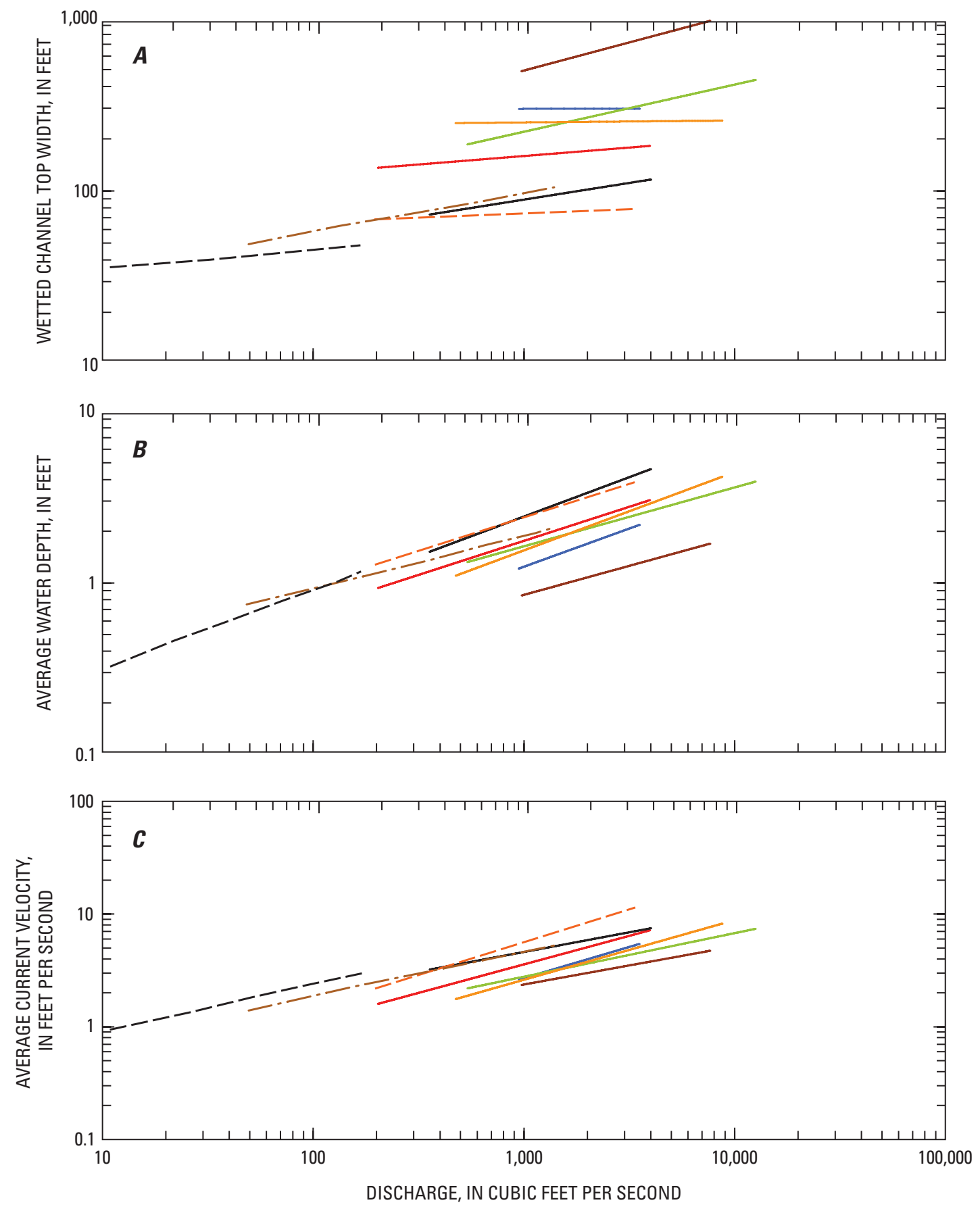

EXPLANATION

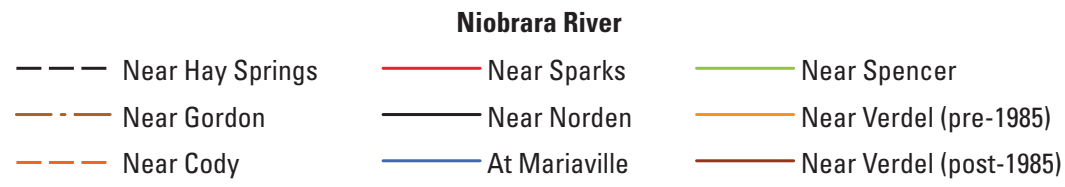

Figure 3. At-a-station hydraulic geometry relations for selected streamflow-gaging stations on the Niobrara River, showing relations between discharge and $(A)$ wetted channel top-width; $(B)$ average water depth; and $(C)$ average current velocity (from Alexander and others, 2009). 
Table 1. At-a-station hydraulic geometry relations for eight selected Niobrara River streamflow-gaging stations.

[All stations are located in Nebraska; all data from Alexander and others, 2009; period of record for each streamflow-gaging station expressed in water years; period of record used for hydraulic geometry analysis may differ from total available period of record for streamflow gage listed; $a$, width coefficient; $b$, width exponent; $c$, depth coefficient; $f$, depth exponent; $k$, velocity coefficient; $m$, velocity exponent; $\mathrm{Q}$, water discharge, in cubic feet per second; $w$, channel top width, in feet; $d$, average channel depth, in feet; $v$, mean current velocity in feet per second; $<$, less than; >, greater than; $\mathrm{ft}^{3} / \mathrm{s}$, cubic feet per second; --, not applicable; $\mathrm{COD}$, coefficient of determination for least-squares estimate of regression equation]

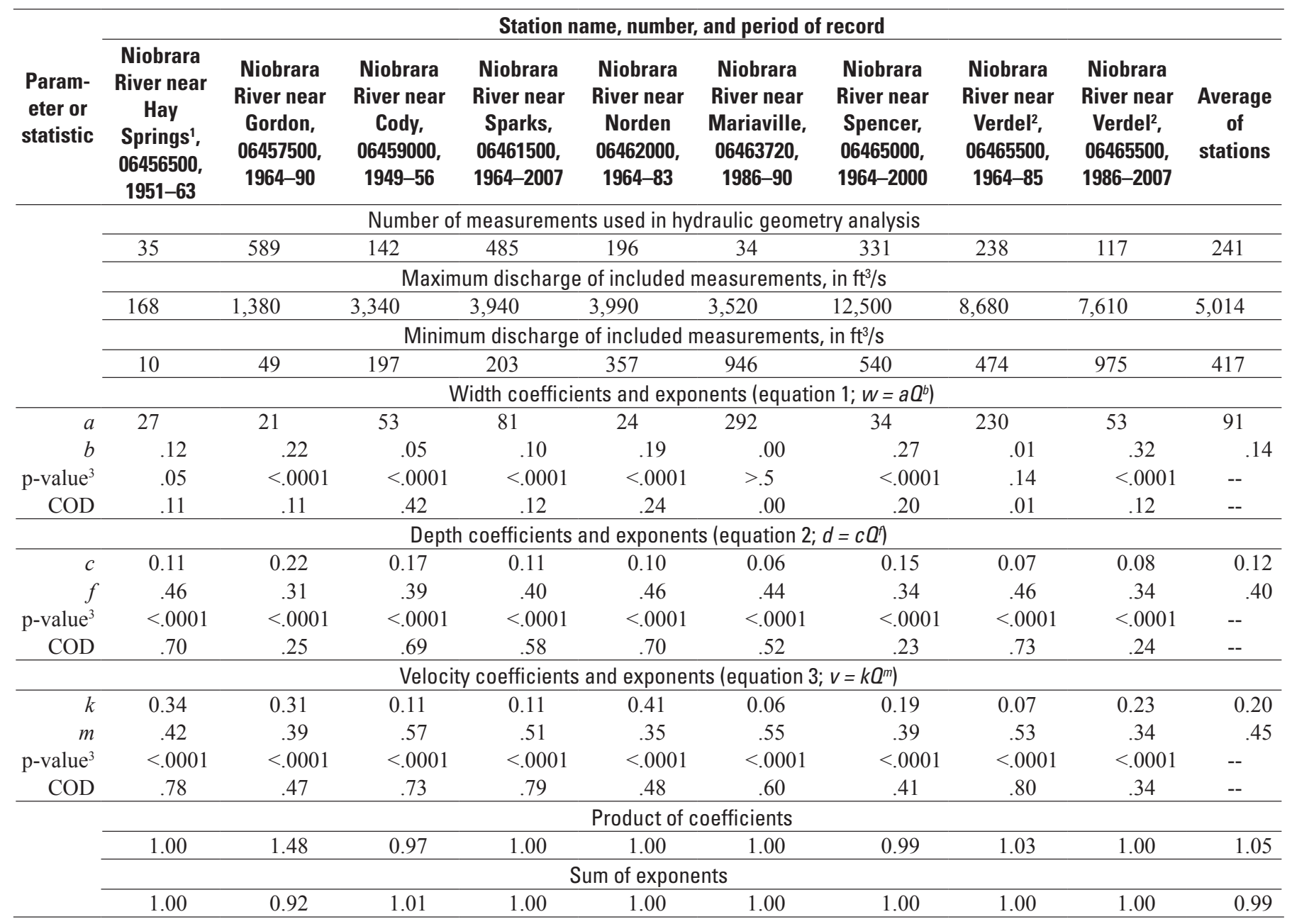

${ }^{1}$ Measurement record for gage near Hay Springs was unavailable for water years 1956-1960.

${ }^{2}$ Verdel gage was moved in 1985 .

${ }^{3}$ Probability (p-value) that regression slope is zero (no correlation between discharge and geometric variable); values less than 0.10 indicate model significance at the 90-percent confidence level. 

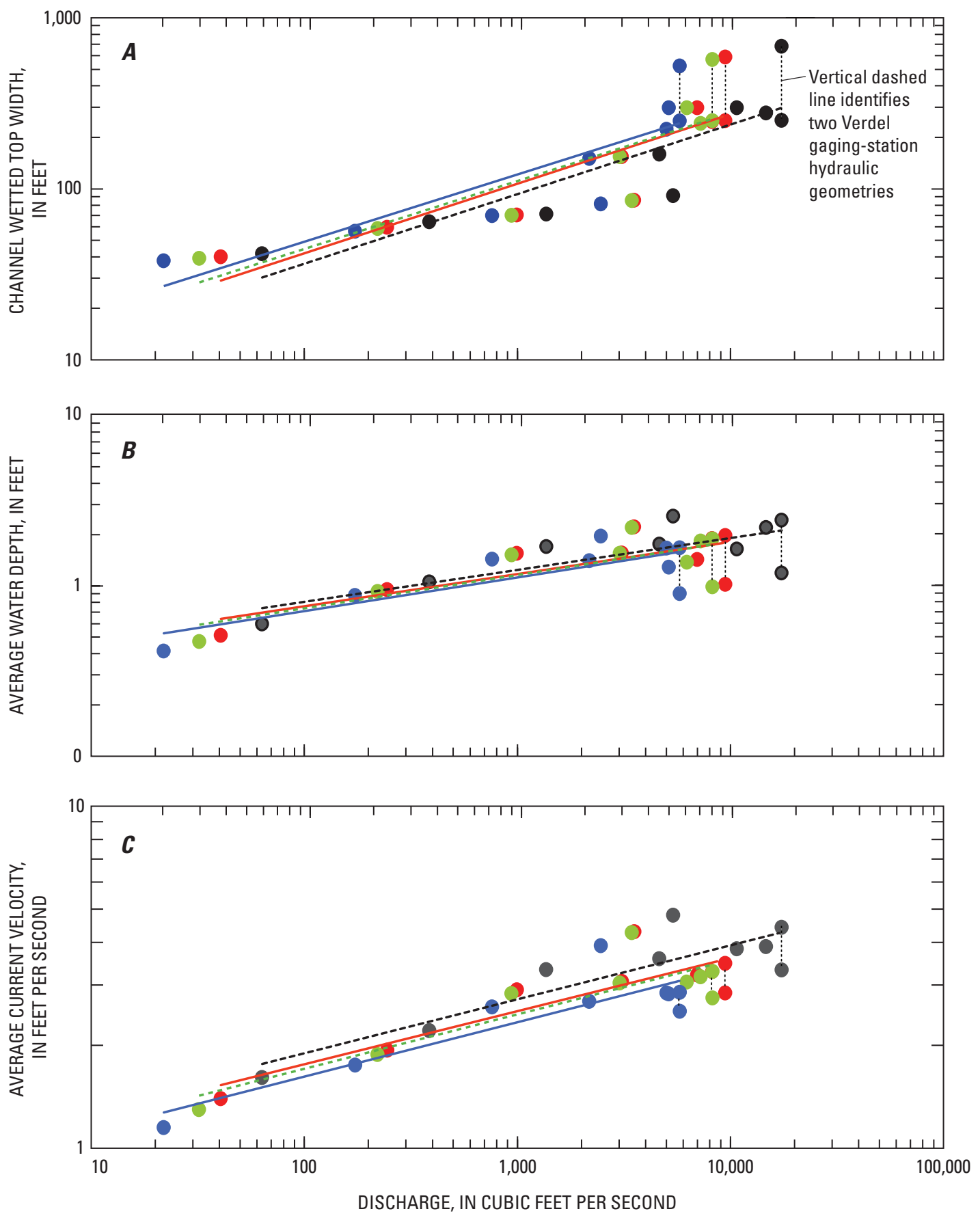

EXPLANATION

\begin{tabular}{|c|c|c|}
\hline & Fitting line & Streamflow condition \\
\hline & Mea & Mean \\
\hline & 10-percent exceedance & 10-percent exceedance \\
\hline 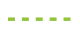 & 50 -percent exceedance & 50-percent exceedance \\
\hline & 75-percent exceedance & 75-percent excee \\
\hline
\end{tabular}

Figure 4. Downstream hydraulic geometry relations for the Niobrara River between the streamflow-gaging station near Hay Springs, Nebraska, and the streamflow-gaging station near Verdel, Nebraska, showing downstream relations between discharge and $(A)$ wetted channel top-width; $(B)$ average water depth; and (C) average current velocity (from Alexander and others, 2009). 


\section{Hydrogeomorphic Segments and Hydraulic Microhabitats of the Niobrara River, Nebraska}

Table 2. Downstream hydraulic geometry relations for the Niobrara River between Hay Springs and Verdel, Nebraska.

[All data from Alexander and others, 2009; \%, percent; $a$, width coefficient; $b$, width exponent; $c$, depth coefficient; $f$, depth exponent; $k$, velocity coefficient; $m$, velocity exponent; $\mathrm{Q}$, water discharge, in cubic feet per second; $w$, channel top width, in feet; $d$, average channel depth, in feet; $v$, mean current velocity in feet per second; $<$, less than; $>$, greater than; $\mathrm{ft}^{3} / \mathrm{s}$, cubic feet per second; COD, coefficient of determination for least-squares estimate of regression equation]

\begin{tabular}{|c|c|c|c|c|}
\hline \multirow{2}{*}{$\begin{array}{l}\text { Parameter or } \\
\text { statistic }\end{array}$} & \multirow{2}{*}{$\begin{array}{l}\text { Mean annual } \\
\text { discharge }\end{array}$} & \multicolumn{3}{|c|}{ Flow exceedance ${ }^{1}$} \\
\hline & & $10 \%$ & $50 \%$ & $75 \%$ \\
\hline & \multicolumn{4}{|c|}{ Maximum discharge used in regression model, in $\mathrm{ft}^{3} / \mathrm{s}$} \\
\hline & 1,708 & 2,695 & 1,540 & 1,180 \\
\hline & \multicolumn{4}{|c|}{ Minimum discharge used in regression model, in $\mathrm{ft}^{3} / \mathrm{s}$} \\
\hline & 29 & 40 & 24 & 18 \\
\hline \multicolumn{5}{|c|}{ Width coefficients and exponents (equation $1 ; w=a Q^{b}$ ) } \\
\hline$a$ & 4.72 & 4.08 & 5.29 & 5.95 \\
\hline$b$ & .54 & .54 & .53 & .52 \\
\hline p-value ${ }^{2}$ & $<.001$ & $<.001$ & $<.001$ & $<.001$ \\
\hline COD & .76 & .77 & .75 & .75 \\
\hline \multicolumn{5}{|c|}{ Depth coefficients and exponents (equation $2 ; d=c Q^{f}$ ) } \\
\hline$c$ & 0.28 & 0.29 & 0.26 & 0.25 \\
\hline$f$ & .25 & .25 & .26 & .26 \\
\hline p-value ${ }^{2}$ & .01 & .01 & .01 & .01 \\
\hline COD & .61 & .62 & .63 & .63 \\
\hline \multicolumn{5}{|c|}{ Velocity coefficients and exponents (equation $3 ; v=k Q^{m}$ ) } \\
\hline$k$ & 0.76 & 0.81 & 0.73 & 0.69 \\
\hline$m$ & .21 & .21 & .21 & .21 \\
\hline p-value ${ }^{2}$ & $<.001$ & $<.001$ & $<.001$ & $<.001$ \\
\hline COD & .77 & .79 & .77 & .77 \\
\hline & \multicolumn{4}{|c|}{ Product of coefficients } \\
\hline & 0.99 & 0.97 & 1.00 & 1.01 \\
\hline & \multicolumn{4}{|c|}{ Sum of exponents } \\
\hline & 1.00 & 1.00 & 1.00 & 1.00 \\
\hline
\end{tabular}

${ }^{1}$ Refers to the percentage of days from period of record that flow exceeded a particular magnitude. See table 1 for values associated with a particular streamflow-gaging station; exceedance was calculated for each gaging station for its particular period of record and used to develop the data values to which hydraulic geometry relations were fitted.

${ }^{2}$ Probability (p-value) that regression slope is zero (no correlation between discharge and geometric variable); values less than 0.10 indicate model significance at the 90-percent confidence level. 


\section{Hydrogeomorphic Segments of the Niobrara River}

The hydrogeomorphic characteristics of the Niobrara River change dramatically along its journey across northern Nebraska. In the previous study by Alexander and others (2009) a process-based classification scheme, composed of four primary descriptive geomorphic "elements" (table 3), was proposed and used to qualitatively describe the longitudinal variation in the physical characteristics of the river: degree of valley confinement, channel-planview pattern, channelwidth variation, and bar configuration. The term "geomorphic segment" was defined as a length of river that has a relatively uniform host of hydrologic and morphologic characteristics. For this report the term "hydrogeomorphic segment" is used instead of "geomorphic segment" to be more consistent with the defined characteristics. Aerial photos and topographic maps of the river valley were used to classify the river into 36 individual hydrogeomorphic segments, each of which had a hypothesized difference in one of the elements from its upstream and downstream bounding segments, but may have been similar to segments elsewhere in the study area. Most of the Niobrara River between Dunlap Diversion Dam and the Missouri River was dominated by width-restricted valley settings, a sinuous channel pattern, highly variable channelwidth, and a braided-bar bed configuration. Although segment boundaries were assigned using the physical descriptors from the classification scheme, no quantitative procedure was applied to test for measurable differences between hydrogeomorphic segments.

Based on natural breaks in the characteristics of the 36 hydrogeomorphic segments, the Niobrara River was divided into 3 broad fluvial geomorphic provinces: an upper province where the channel is narrow and meanders across a broad flood plain; a middle province where the river flows through mixed-valley settings, including narrow canyons and valleys bound by escarpments; and a lower province where the valley and channel are wide, and the river is persistently braided (fig. 5). These provinces were named the Meandering Bottoms (MB), Canyons and Restricted Bottoms (CRB), and the Braided Bottoms (BB), respectively (Alexander and others, 2009) (fig. 5). The fluvial geomorphic provinces also corresponded closely in space to changes in bedrock lithology at the level of the river with the CRB province exhibiting the greatest range in channel-form characteristics, channel slope, and bedrock lithology among segments (fig. 2).

\section{Approach and Methods}

The study described in this report builds upon previous work by Alexander and others (2009) and is intended to compile a hydrogeomorphic framework for future, more detailed physical and biological investigations. The study approaches the analysis of hydrogeomorphic segments and hydraulic microhabitats of the Niobrara River at two spatial scales. First, a characterization of the physical attributes along the length of the Niobrara River and its valley is presented at a basin scale and hydraulic microhabitats are assessed for fluvial geomorphic provinces within the basin. Second, at the reach scale, field measurements from four study reaches are used to examine the variation of elevation and geomorphic processes associated with fluvial landforms, and the channel hydraulic geometry, hydraulics, and hydraulic microhabitats within the Scenic Reach of the Niobrara River.

\section{Basin-Scale Methods}

Existing topographic data, aerial photographic images, and stream-hydraulic information were compiled and used to investigate the longitudinal variation in the hydrogeomorphic, hydraulic, and aquatic microhabitat attributes of the Niobrara River from Dunlap Diversion Dam to the Missouri River (fig. 1). The basin-scale investigation included three tasks: a GIS analysis and characterization of the longitudinal hydrogeomorphic attributes of the river; statistical analysis of previously determined longitudinal hydrogeomorphic segments (Alexander and others, 2009); and estimation of hydraulic microhabitat characteristics in the three fluvial geomorphic provinces of the Niobrara River. Although the GIS analysis was used as the basis for the statistical analysis, the methods for the statistical analysis are presented first because the results of the statistical analysis ultimately had an effect on the organization and final descriptions of the physical characteristics of the geomorphic segments.

\section{Statistical Analysis of Fluvial Geomorphic Provinces and Hydrogeomorphic Segments of the Niobrara River}

A river can be described in many different ways, and numerous classification systems, spanning several scientific disciplines, have been proposed and used by water resource scientists and managers (Kondolf, 1995). The process-based, segment-scale classification scheme for the Niobrara River is composed of a framework of four primary geomorphic "elements" (table 3): (A) degree of valley confinement; (B) channel-planview pattern; (C) channel-width variation; and (D) bar configuration. Each element has three or more "classes" that broadly describe the variation in physical "condition" within each element (table 3). Boundaries of hydrogeomorphic segments were assigned where an abrupt and persistent difference in one or more of the classes was identified in the river by examining aerial photographs. The classification used the assumption that broad differences in channel form characteristics were the result of differences in river processes, and these differences likely translate into variation in aquatic and riparian macro-habitat characteristics. Although this assumption is potentially a drastic simplification of the Niobrara River aquatic and riparian ecosystems, it 
Table 3. Segment-scale geomorphic classification system for the Niobrara River, Nebraska (adapted from Alexander and others, 2009).

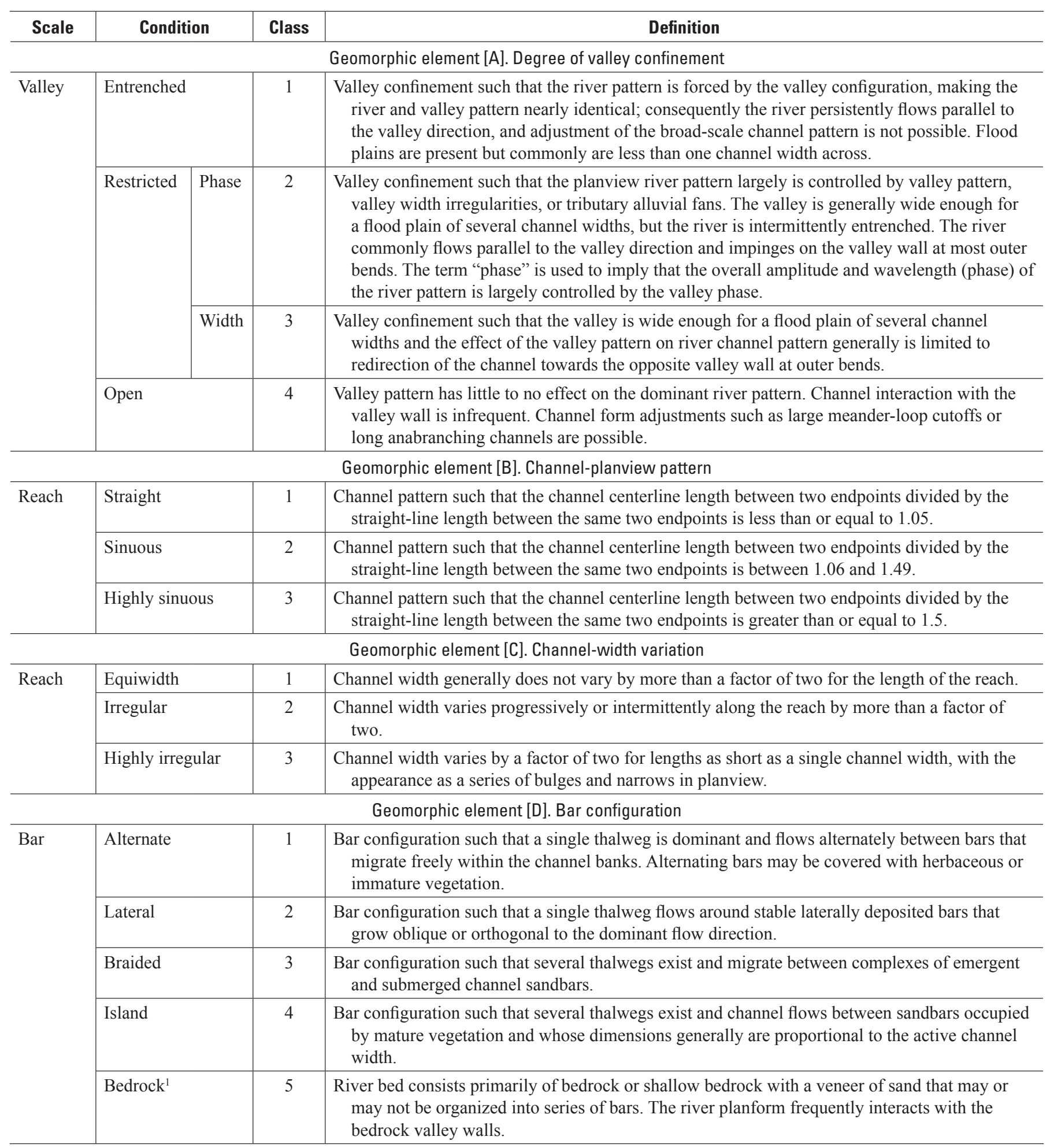

${ }^{1}$ Added by the authors for this study. 

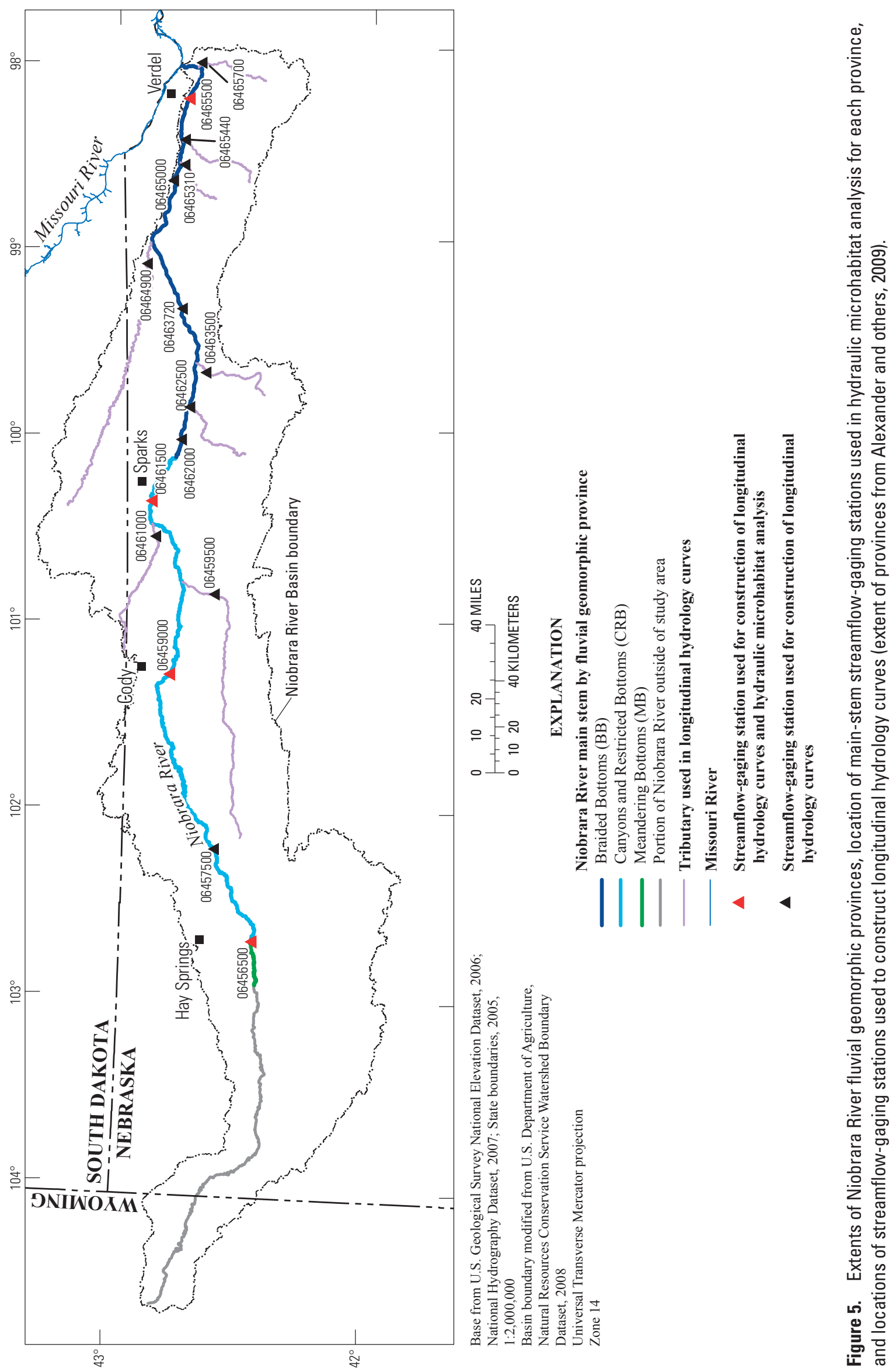
provides an initial basis to describe and quantify the spatial variation of the river within the study area.

The purpose of the statistical analysis herein is to assign physiographic and hydrogeomorphic metrics to the descriptive elements, and use them to determine if the hydrogeomorphic segments, as defined by their various combinations of descriptive elements (table 3), are measurably different from their upstream and downstream bounding segments. For this analysis, each of the 36 hydrogeomorphic segments, although assigned manually, were hypothesized to have measureable differences in one or more of the classification elements (table 3) from an upstream or downstream bounding segment. It also was assumed that the classes from each of the primary geomorphic elements (table 3 ) were assigned to each segment in a mostly correct manner. For example, the bar configuration class assigned to each segment was assumed to be the dominant bar type, but surely not the only bar type present, and, therefore, human error could have assigned the incorrect dominant bar type. Based on field observations, reaches classified as "entrenched" with no bars visible in the aerial photographs were assumed to be bedrock-dominated on the bed or banks. Subsequently, a fifth class, bedrock, was added to the bar configuration element proposed by Alexander and others (2009) to account for the dominance of bedrock in such reaches (table 3 ).

Seven hydrogeomorphic variables (table 4) were derived from the GIS analysis, hydrology data, and elevation data, and for each of the channel centerline sampling points (identified using the GIS centerline addressing system described in the next section), the value of each variable was measured or estimated. The variables chosen were primarily based on a combination of descriptive power, simplicity, and geomorphic relevance. Additionally, because the study area spans over 350 $\mathrm{mi}$ of the Niobrara River, and the river grows dramatically in width and discharge over this length, the variables chosen were either dimensionless, width-normalized, or were not directly related to the width or discharge of the channel (table 4). Variable simplicity was necessary to efficiently derive the metrics from the GIS sampling scheme. For example, numerous ways of calculating the sinuosity and braided index of a river channel have been used in the geomorphic literature (Knighton, 1998); however, for the purposes of this analysis, the most basic forms of sinuosity and braided index were used because these metrics were suited to rapid, consistent, and straightforward calculation from the GIS sampling data set.

The statistical procedure consisted of two primary steps: (1) assignment of variables to each element using an analysis of variance (ANOVA) and multiple comparison procedure, and (2) discriminant analysis of hydrogeomorphic segments using the assigned hydrogeomorphic variables as predictors. All statistical procedures were performed using Spotfire S+ software (TIBCO Software Incorporated, 2008). Only the ordinal ranks of the points for each variable were used, as opposed to the variable values themselves, for all steps in the statistical procedures, so that no distribution or variance assumptions were necessary (non-parametric). Although non-parametric techniques reduce the inferential power of these procedures for variables with normal distributions of

Table 4. Names and abbreviations for hydrogeomorphic variables used in statistical analysis of hydrogeomorphic segments.

\begin{tabular}{ccc}
\hline Variable name & Abbreviation & Definition \\
\hline Channel sinuosity & SIN_100 & $\begin{array}{l}\text { Ratio of the channel centerline length between two points divided by the straight-line } \\
\text { length between the same two points as calculated over } 100 \text { channel widths centered } \\
\text { on the sampling point. }\end{array}$
\end{tabular}

Valley confinement CHAN_VAL_RAT Ratio of the channel width to the valley width at the sampling point.

Braided index $\quad$ BI $\quad \begin{aligned} & \text { Number of channel threads averaged over a 30-channel width window centered on the } \\ & \text { sample point. }\end{aligned}$

Stream power SP_90 Unit stream power of the sampling point at the 90th-percentile (10 percent-exceedance) discharge.

Wall proximity WAL_PROX Minimum distance from a channel bank, right or left, to the valley wall.

Channel-width variability CHAN_CV Ratio of the standard deviation to the mean of channel width as measured over a distance of 100 channel widths centered on the sampling point.

Valley sinuosity CH_VAL_LEN Ratio of the centerline length of the river channel to the centerline length of the bounding valley as calculated over 100 channel widths centered on the sampling point. 
constant variance, sample sizes were large enough to reduce the need for the power of parametric procedures (Helsel and Hirsh, 2002).

Although numerous statistical methods exist for classifying objects based on a given set of variables, assumptions were made on the basis of the previous investigation (Alexander and others, 2009) that the number of descriptive elements and their associated number of classes were adequate, and that the chosen variables were adequate descriptors of at least some of those classes (table 4). Using these assumptions, ANOVA models (TIBCO Software Inc., 2008) were created for each hydrogeomorphic variable to test its ability to distinguish the previously assigned classes within each geomorphic element. To test if each variable could distinguish between the assigned classes, multiple comparison analysis (MCA) procedures were performed on each ANOVA model using an alpha value of 0.05 (95 percent confidence). The Tukey (1953) multiple comparison test was used for all elements with three or more classes. The Fisher (1949) least-significant differences test was used for the "Channel Planview Pattern" element because only two classes were identified for the element within the study area by Alexander and others (2009). If either MCA analysis indicated that a variable was capable of distinguishing the same number of classes as had previously been defined for the associated geomorphic element, then it was assumed to be a candidate or potential predictor for multivariate discriminant analysis.

Once each variable had been tested for its discriminating ability, an iterative procedure was used to build a final, predictive discriminant function for each element. First, a primary hydrogeomorphic variable was chosen from the pool of predictor variables on the basis of results from the ANOVA procedure. The primary hydrogeomorphic variable was different for each geomorphic element, and was considered to be the most physically relevant to the associated element. For example, channel sinuosity was chosen as a primary predictor of channel-planform pattern, and braided index was chosen as a primary predictor of channel-bar configuration (table 4). Discriminant analysis was first applied using this single primary variable as a class predictor. The remaining candidate variables were added iteratively to the discriminant model, and remained in the model only if the maximum class error (maximum misclassification rate among individual classes) and overall model prediction error (total misclassification rate) were both reduced by the inclusion of the variable in the discriminant function. The procedure was continued until all candidate predictor variables had been tested. The discriminant function with the lowest maximum and total error then was used to assign each channel-sampling point to a class for each geomorphic element. In addition to error percentage, the Wilks' lambda test statistic was used to assess the proportion of the variance in the multi-variate combination of variables that was unaccounted for by grouping (discriminating) using the geomorphic element classes (Everitt and Dunn, 1991). The Wilks' lambda test statistic was approximated to an $\mathrm{F}$ distribution, and assigned a probability value ( $\mathrm{p}$-value) at the 95-percent confidence level. A low probability value for the Wilks' lambda test statistic was interpreted as a signal that the means between element classes were statistically distinguishable (unequal).

The combination of predicted class assignments then was compared to the hydrogeomorphic segment combinations proposed by Alexander and others (2009). If a particular segment showed any different class assignments, the new combination was compared to bounding upstream and downstream segment class combinations to determine if either was classified differently. If the combination was different from the upstream and downstream segments, the segment remained a unique segment. If the segment was classified identically to an upstream or downstream bounding segment, it was considered statistically indistinguishable and combined with that segment.

\section{Geographic Information System Analysis of Niobrara River and Valley Morphometry}

In collaboration with the University of Nebraska Center for Advanced Land Information Technologies (CALMIT), four primary spatial data sets were constructed and used to quantify the longitudinal variation in Niobrara River hydrogeomorphic characteristics: Niobrara channel centerline, active channel boundaries, island boundaries, and valley-wall boundaries (fig. 6). The Niobrara channel centerline was constructed by digitizing onscreen in a GIS while superimposed on the 2003 Farm Service Agency natural-color aerial-ortho photographs at 1:5,000 scale (U.S. Department of Agriculture, 2004).

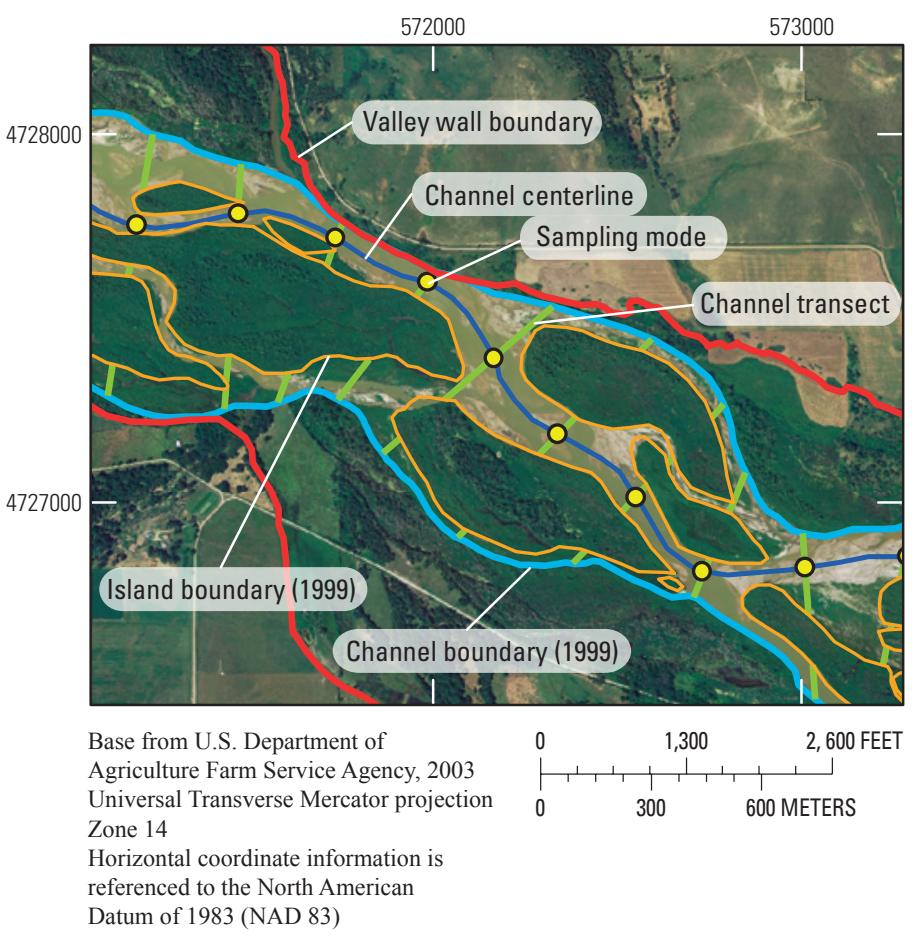

Figure 6. Example of digital geographic data sets used to sample Niobrara River channel and valley morphologic characteristics. 
The Niobrara active channel boundaries and valley-wall boundaries were constructed from the 1999 U.S. Geological Survey aerial-ortho photographs (Nebraska Department of Natural Resources, 2004). The non-vegetated area of the visible channel was used as a proxy for the "active" channel, a method that has been used widely by other investigators of alluvial rivers (Williams, 1978; Nadler and Schumm, 1981; Johnson, 1994; Van Steeter and Pitlick, 1998; Allred and Schmidt, 1999; Grams and Schmidt, 2002). Where visible, the boundaries of vegetated islands within the active channel also were digitized as individual polygons. The 1999 blackand-white aerial photographs were used to define the active channel boundaries because the period of water years 2000 to 2006 included several years of unusually low flow, and the channel may have narrowed temporarily during that short period. Finally, the boundaries of the valley wall were digitized based on a combination of the 2003 U.S. Department of Agriculture, Farm Service Agency (FSA) natural-color aerial-ortho photographs and the digital USGS 7.5-minute topographic quadrangles (http://topomaps.usgs.gov/drg/). The valley-wall boundary was defined as the across-valley interface between landforms created by hillslope processes and landforms deposited by alluvial processes. Tributary alluvial fans depositing on the valley flat and terrace deposits were considered part of the alluvial valley bottom, and, therefore, were not used as valley-wall boundaries.

To systematically quantify the width of the channel, width of the valley bottom, and number of islands within the Niobrara River, a longitudinal sampling strategy was devised using an addressing system along the channel centerline. The active-channel boundaries of the river within the study area were converted to a single polygon. The polygon was then subdivided into three separate polygons using the boundaries of the three fluvial geomorphic provinces: the Meandering Bottoms, Canyons and Restricted Bottoms, and Braided Bottoms (fig. 5). The average channel width of each fluvial geomorphic province was estimated by dividing the area of each polygon by the centerline length of the Niobrara River within it. The channel centerline within each fluvial geomorphic province was converted into a series of sampling nodes, spaced one average channel width apart (fig. 6). A centerline distance was assigned to each sampling node beginning at the former Chicago and Northwestern Railroad Bridge near the Missouri River confluence. A transect was centered on each sampling node, aligned perpendicular to the channel centerline, and spanned at least the width of the channel. The location of each transect upstream from the Missouri River was assigned using the centerline distance of the sampling node it was centered on. The width of the active channel was estimated at each node by clipping the transect lines using the active-channel boundary data set, then subtracting the width of the transect that intersected each island. To calculate the number of islands at each sampling node, the transect lines were intersected with the island polygons in the GIS, which erased the portion of each transect outside of the islands, and assigned the identification number of the overlying transect to each island. The number of islands at each node was counted by summing the number of lines with common identification codes. It should be noted that the width of the river in a short segment below Dunlap Diversion Dam could not be digitized accurately at the 1:5,000 scale, nor any scale, because of a lack of photographic resolution of channel boundaries in the 1999 photographs. For this section of river, the approximate boundaries of the channel were digitized and adjusted based on the ratio of the average width of the channel as compared to the average width of the river at 60 sampling nodes immediately upstream and downstream from the short segment.

The potential for a river to transport sediment is largely based on a combination of its flow regime and channel geometry, the latter of which may be affected by bedrock geology or vegetation. Stream power is a metric commonly used by engineers and geomorphologists to assess the energy expenditure of the river on its bed and banks and may be used as a measure of the potential for a river to transport sediment (Bagnold, 1977 ; Bull, 1979). Stream power $(\Omega)$ is defined as:

$$
\Omega=\gamma \mathrm{Q} s
$$

The variables $\gamma, \mathrm{Q}$, and $s$, are the specific weight of water, river discharge, and channel slope, respectively. To compare rivers and reaches of river with largely differing discharges, stream power often is divided by channel width to determine "unit stream power." Unit stream power can be used as a predictor of sediment transport (Yang, 1973), particularly bedload transport (Bagnold, 1977), as well as a predictor of channel bedforms (Simons and Richardson, 1966).

As a measure of the longitudinal variation in sediment transport potential, unit stream power was estimated at each sampling node. Calculation of longitudinal unit stream power required the assignment of discharge and slope values to each sampling point. Longitudinal hydrology curves were generated using the Niobrara main channel and tributary streamflowgaging station data. The locations of main stem and gaged tributaries were assigned distances along the Niobrara River channel centerline using the addressing system for sampling nodes described above. The daily streamflow data for each main stem gage was used to create discharge duration curves and derive the mean, median, and 10-percent exceedance (90th percentile) discharge for each of the streamflow-gaging stations (table 5). To maintain consistency with a previous study (Alexander and others, 2009), where possible, only the post-1963 period of approved record (through water year 2008) was used to create the discharge duration curves. The longitudinal hydrology curves were formulated by linear interpolation between each successive gage for a particular discharge-frequency value while taking into account any abrupt increases (of the same discharge-frequency value) from gaged tributaries between the two stations (fig. 7). Discharge for a particular exceedance frequency at each sampling point was estimated by interpolating along the slope between gages and tributaries. Finally, the longitudinal profile of the Niobrara River (fig. 2) was used to assign elevation values to each 
Table 5. Streamflow-gaging stations used to construct longitudinal hydrology curves of the Niobrara River from Dunlap Diversion Dam to the Missouri River.

[Gages listed in order from upstream to downstream; all stations are located in Nebraska; River mile, location along channel centerline in distance upstream from the Missouri River confluence with the Niobrara; $\mathrm{Q}_{\mathrm{xx}}$, discharge of " $\mathrm{xx}$ " percentile frequency from discharge duration curve; $\mathrm{ft}^{3} / \mathrm{s}$, cubic feet per second]

\begin{tabular}{|c|c|c|c|c|c|c|}
\hline Station name & Station number & Period of record & River mile & $\mathbf{O}_{50}\left(\mathrm{ft}^{3} / \mathrm{s}\right)$ & $\mathbf{0}_{\text {mean }}\left(\mathrm{ft}^{3} / \mathbf{s}\right)$ & $\mathbf{Q}_{90}\left(\mathrm{ft}^{3} / \mathrm{s}\right)$ \\
\hline Niobrara River near Hay Springs ${ }^{1}$ & 06456500 & $1952-1964$ & 317 & 23 & 27 & 40 \\
\hline Niobrara River near Gordon & 06457500 & 1947-1991 & 281 & 105 & 115 & 162 \\
\hline Snake River near Burge & 06459500 & 1964-1994 & 173 & 187 & 154 & 272 \\
\hline Minnechaduza Creek at Valentine & 06461000 & 1949-1994 & 150 & 30 & 34 & 56 \\
\hline Niobrara River near Norden & 06462000 & $1964-1983$ & 119 & 787 & 810 & 1,120 \\
\hline Plum Creek at Meadville & 06462500 & 1964-1994 & 109 & 96 & 104 & 130 \\
\hline Long Pine Creek near Riverview & 06463500 & $1964-2007$ & 97 & 159 & 168 & 209 \\
\hline Niobrara River at Mariaville & 06463720 & 1986-1991 & 80 & 1,260 & 1,358 & 1,870 \\
\hline Keya Paha River near Naper & 06464900 & 1958-1994 & 59 & 74 & 139 & 290 \\
\hline Niobrara River near Verdel ${ }^{1}$ & 06465500 & $1964-2007$ & 15 & 1,530 & 1,705 & 2,700 \\
\hline Verdigre Creek near Verdigre & 06465700 & $2003-2007$ & 5 & 100 & 117 & 172 \\
\hline
\end{tabular}

${ }^{1}$ Used in hydraulic microhabitat analysis.

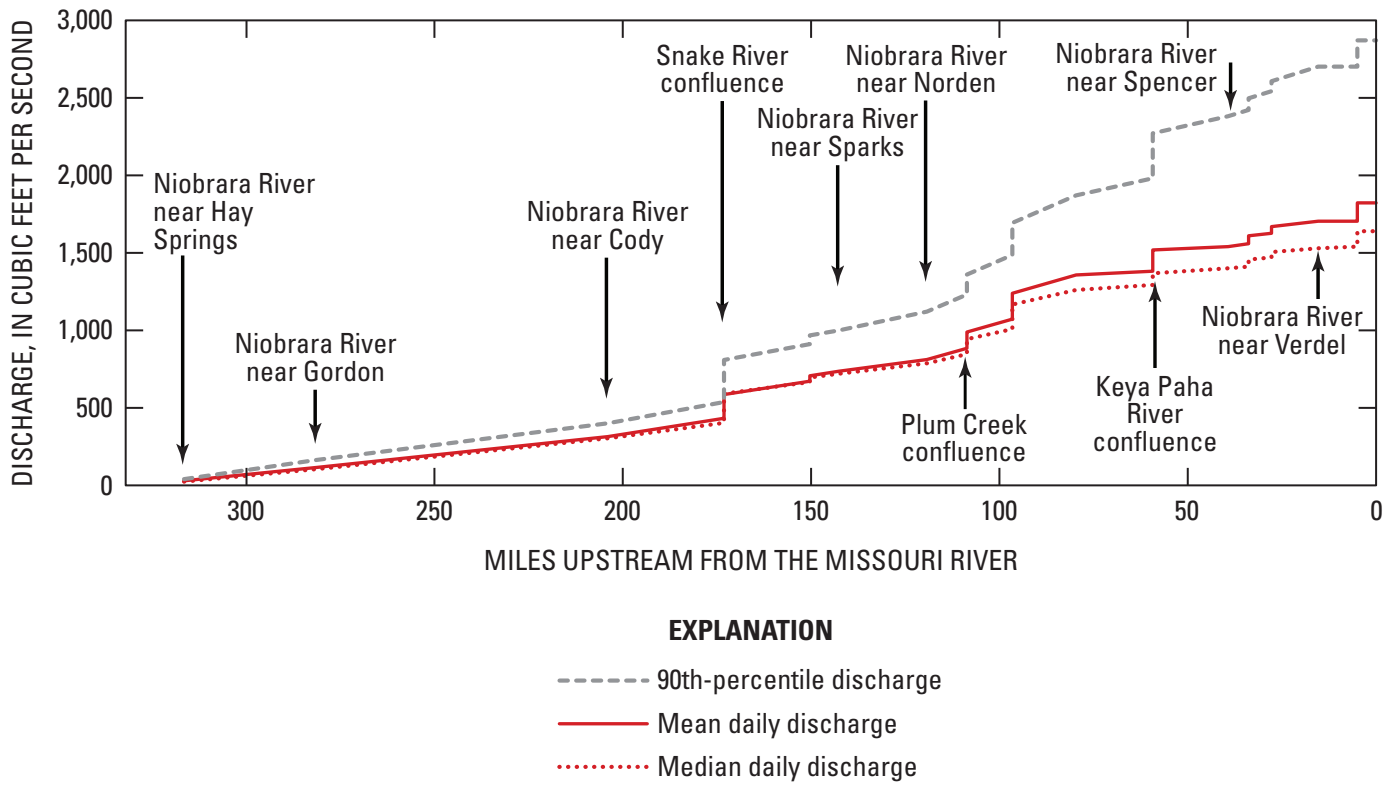

Figure 7. Longitudinal hydrology curves of the Niobrara River used for along-stream calculation of unit stream power. 
sampling point. The average channel slope assigned to each sampling point then was calculated across 100 channel widths, centered on the sampling point (50 channel widths upstream and 50 channel widths downstream). In reaches near main channel dams, the slope calculations were truncated at the dam. For example, the slope for a point immediately upstream from the dam crest would only include the 50 channel widths upstream and none downstream; the slope for a point immediately downstream from the dam face only included the 50 channel widths downstream.

\section{Calculation of Hydraulic Microhabitats in Fluvial Geomorphic Provinces of the Niobrara River}

At the scale of a river reach, hydraulic variables such as flow depth and velocity exert important effects on the types of aquatic habitat available for organisms (Stalnaker and others, 1996; McKenny, 1997). The distributions of flow depth and velocity combinations in a reach of river are a function of several factors including channel geometry, bed configuration, and flow regime (Maddock, 1999; Bridge, 2003). The automatic hydraulic microhabitat calculator developed by Ginting (Ginting and Zelt, 2008) was used to demonstrate the types and extents of hydraulic habitats available in different fluvial geomorphic provinces over a range of flow regimes. This tool characterizes the extent of hydraulic habitat niches along the cross section using a matrix of three depth and three velocity classes (table 6). Depth classes were defined as shallow, intermediate, and deep, corresponding to class boundaries of less than $1 \mathrm{ft}, 1$ to $2 \mathrm{ft}$, and deeper than $2 \mathrm{ft}$, respectively. Velocity classes were defined as slow, moderate, and swift, corresponding to class boundaries of less than $1 \mathrm{ft}$ per second ( $\mathrm{ft} / \mathrm{s}), 1$ to $2 \mathrm{ft} / \mathrm{s}$, and greater than $2 \mathrm{ft} / \mathrm{s}$, respectively. The hydraulic habitat nomenclature uses the respective depth and velocity class names. For example, an area of the channel with depth less than $1 \mathrm{ft}$ and velocity between 1 and $2 \mathrm{ft} / \mathrm{s}$ would be classified as "shallow-moderate." Although the hydraulic habitat niches were originally defined for fish species of the Platte River (Peters and Holland, 1992), many of the same fish species were found in samples of the main stem and tributaries of the Niobrara National Scenic River (Dietsch, 2007).

To compare differences in habitat types and distributions in different geomorphic provinces of the Niobrara study area, four gaging stations were chosen to represent the hydraulic environments of each province. The Niobrara River near Hay Springs (station number 06456500) was chosen to represent the Meandering Bottoms (MB) province; the Niobrara River near Cody (station number 06459000) and near Sparks (station number 06461500) were chosen to represent the Canyons and Restricted Bottoms (CRB) province; and the Niobrara River near Verdel (station number 06465500) was chosen to represent the Braided Bottoms (BB) province (fig. 5). For convenience, these stations are hereinafter referred to only as Hay Springs, Cody, Sparks, and Verdel, respectively. To investigate the range of habitat types and distributions at each gage over a range of flow regimes, two measurements were chosen from each of three flow exceedance categories: upper decile (less than 10-percent exceedance), median quantile (25- to 75-percent exceedance), and lower decile (greater than 90-percent exceedance).

\section{Study Reaches along the Niobrara National Scenic River}

Hydrogeomorphic segments are composed of several individual river reaches. The term "reach" is used herein to describe a length of river space that has one or more repeated sequences of hydraulic characteristics (Frissel and others, 1986). A familiar example of such a sequence would be a pool-riffle coupling in a meandering river channel. The USGS and NGPC selected four study reaches within the Scenic Reach of the Niobrara River to investigate reach-scale hydraulics, hydraulic geometry, bed-sediment characteristics, fluvial landforms, and hydraulic microhabitats (fig. 8). For the purposes of brevity, these reaches are hereinafter referred to as Crooked, Sunny Brook, Muleshoe, and Rock Barn, respectively (table 7).

The locations of each study reach were identified by USGS and NGPC personnel prior to the hydrogeomorphic segmentation process and were selected primarily on the basis of a combination of hydraulic uniformity along the reach, presence of alluvial banks and landforms, and access considerations. Hydraulic uniformity was important to minimize uncertainty in the discharge and channel resistance measurements, and alluvial banks were important to accommodate unrestricted alluvial channel adjustments over a range of discharges. Four cross sections were established within each study reach, spaced approximately one channel width apart (fig. 9). Initial topographic surveys of the cross sections were performed by NGPC personnel using real-time kinematic (RTK) Global Positioning System (GPS) technology (J. Miller, Nebraska Game and Parks Commission, unpublished data, 2008). The cross sections at each study reach were numbered in downstream order from 1 to 4 .

\section{Characterization of Fluvial Landforms and Bed Sediment}

Rivers adjust their banks and build flood plains such that the channel geometry is capable of efficiently transporting, within an associated hydrologic regime, the caliber and mass of sediment received from upstream. For the purposes of this report, Nanson and Croke's (1992) definition of a "genetic" flood plain was used: the largely horizontally bedded alluvial landform adjacent to a channel, separated from the channel by banks, and built of sediment transported by the present flow regime. Flood plains are primary depositional features of alluvial rivers, and their treads are commonly used as indicators of the elevation of the stage of some physically relevant discharge (bankfull, dominant, or effective 
Table 6. Typical association between fish species and matrix of depth and velocity combinations defined as hydraulic habitat niches for microhabitat analysis (adapted from Ginting and Zelt, 2008).

[Depth and velocity classes and associated species based on Peters and Holland (1992), except where indicated; ft, foot; ft/s, feet per second]

\begin{tabular}{|c|c|c|c|}
\hline \multirow{2}{*}{ Water depth } & \multicolumn{3}{|c|}{ Current velocity } \\
\hline & Slow (slower than $1 \mathrm{ft} / \mathrm{s}$ ) & Moderate $(1-2 \mathrm{ft} / \mathrm{s})$ & Swift ( faster than $2 \mathrm{ft} / \mathrm{s}$ ) \\
\hline \multirow[t]{16}{*}{ Shallow (shallower than $1 \mathrm{ft}$ ) } & Notropis blennius & Hybognathus placitus & Aplodinotus grunniens \\
\hline & (River shiner) & (Plains minnow) & (Freshwater drum) \\
\hline & Cyprinella lutrensis & & \\
\hline & (Red shiner) & Hybognathus argyritus & \\
\hline & Notropis stramineus & (Silvery minnow) & \\
\hline & (Sand shiner) & & \\
\hline & Hybognathus placitus & Platygobio gracilis & \\
\hline & (Plains minnow) & (Flathead chub) & \\
\hline & Hybognathus argyritus & & \\
\hline & (Silvery minnow) & Ictalurus punctatus & \\
\hline & Platygobio gracilis & (Channel catfish) & \\
\hline & (Flathead chub) & & \\
\hline & Carpiodes cyprinus & & \\
\hline & (River carpsucker) & & \\
\hline & Carpiodes carpio & & \\
\hline & (Quillback) & & \\
\hline \multirow[t]{6}{*}{ Intermediate (1-2 ft) } & Cyprinella lutrensis & Ictalurus punctatus & \\
\hline & (Red shiner) & (Channel catfish) & \\
\hline & Ictalurus punctatus & & \\
\hline & (Channel catfish) & Aplodinotus grunniens & \\
\hline & Aplodinotus grunniens & (Freshwater drum) & \\
\hline & (Freshwater drum) & & \\
\hline \multirow[t]{6}{*}{ Deep (deeper than $2 \mathrm{ft}$ ) } & Cyprinella lutrensis & lctalurus punctatus & Ictalurus punctatus \\
\hline & (Red shiner) & (Channel catfish) & (Channel catfish) \\
\hline & Ictalurus punctatus & Aplodinotus grunniens & Aplodinotus grunniens \\
\hline & (Channel catfish) & (Freshwater drum) & (Freshwater drum) \\
\hline & & & Scaphirhynchus sp. ${ }^{1}$ \\
\hline & & & (Sturgeon) \\
\hline
\end{tabular}

\footnotetext{
${ }^{1}$ Based on studies by Bramblett and White (2001) and Wildhaber and others (2007); the deep-swift niche is the preferred habitat by pallid sturgeon (Scaphirhynchus albus) and shovelnose sturgeon (Scaphirhynchus platorynchus) during their adult life.
} 


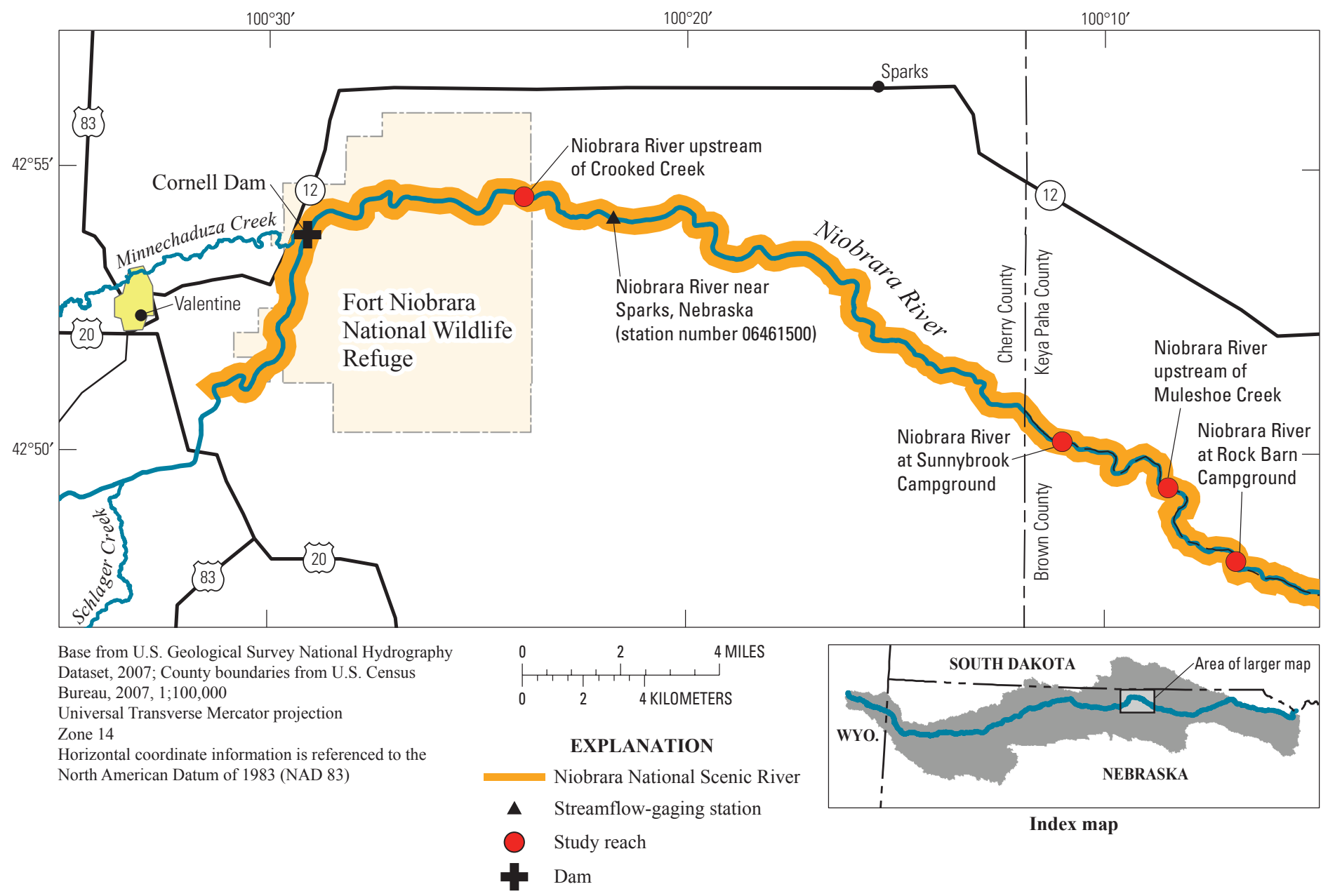

Figure 8. Location of four reaches within Niobrara National Scenic River where fluvial landforms, bed sediment, and channel hydraulic geometry and hydraulics were studied.

Table 7. Stations used to index study reaches within the 76-mile Niobrara National Scenic River, Nebraska.

\begin{tabular}{lllcc}
\hline \multicolumn{1}{c}{ Station name } & Station number & $\begin{array}{c}\text { Short name } \\
\text { used in text }\end{array}$ & $\begin{array}{c}\text { Location in miles } \\
\text { upstream from } \\
\text { Missouri River }^{1}\end{array}$ & $\begin{array}{c}\text { Reach length, } \\
\text { in feet }^{2}\end{array}$ \\
\hline Upstream of Crooked Creek near Sparks, Nebraska & 425429100235301 & Crooked & 144.8 & 460 \\
At Sunny Brook Campground near Norden, Nebraska & 425013100105801 & Sunny Brook & 129.9 & 430 \\
At Muleshoe Creek near Norden, Nebraska & 424925100083201 & Muleshoe & 126.7 & 530 \\
At Rock Barn Campground near Norden, Nebraska & 424809100065001 & Rock Barn & 123.8 & 530 \\
\hline
\end{tabular}

${ }^{1}$ Refers to location of station point indexed in U.S. Geological Survey National Water Information System (http://waterdata.usgs.gov/nwis).

${ }^{2}$ Straight-line distance between the center points of the most upstream and most downstream cross sections within the reach. 


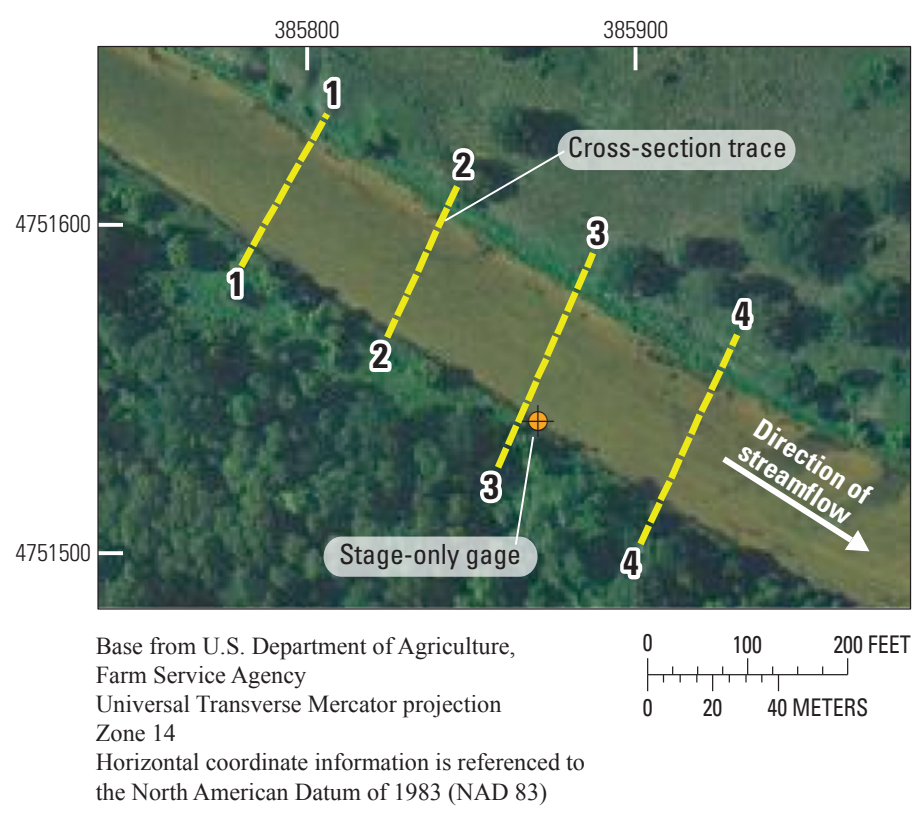

Figure 9. Layout of channel cross sections at Niobrara River upstream from Crooked Creek near Sparks, Nebraska (425429100235301), exemplifying four study reaches.

discharge), which may or may not be responsible for the maintenance and configuration of the present-day channel geometry (Nanson, 1986; Knighton, 1998). Abandoned flood plains, also known as terraces, may be indicative of several geomorphic processes, which may or may not be ongoing during the present-day hydrologic regime including: channelbed incision, changes in flood-discharge magnitudes, channel backwater hydraulics from debris or ice jams, or catastrophic floods (Kochel and Baker, 1988; Pazzaglia and others, 1998; Pederson and others, 2006; Moody and Meade, 2008; Boucher and others, 2009).

\section{Fluvial Landforms}

A combination of field observations and survey data from each of the four cross sections within the study reaches was used to characterize and classify the flat-lying alluvial surfaces adjacent to the channel. The ranges of elevations of the fluvial landforms were indexed by referencing the elevation of the brink (the minimum elevation) of each surface to the local elevation of the stage of the long-term median daily discharge from the Niobrara River near Sparks (station number 06451500). The stage of the long-term median discharge was determined first by linearly interpolating between the stages of the bracketing discharge measurements. The elevation of the stage of the median discharge at cross sections where stages were not recorded was estimated by linearly interpolating using the average water-surface slope and the channel centerline distance between cross sections.
At the Crooked study reach, the record from a continuous-recording stage sensor (stage-only gage) was used in combination with the 15-minute interval gage record from the Niobrara River near Sparks to approximate a stage-discharge relation; the stage-discharge relation was approximated by applying a 1-hour lag time to the stage data from the Niobrara River upstream from Crooked and assigning the associated 15-minute interval discharge data from the Niobrara River near Sparks. The 1-hour lag time was used as an estimate of the average travel time of water between the two stations. This rough stage-discharge relation was applied in the Crooked study reach only, and enabled a coarse estimate of the discharge associated with inundation of the fluvial landforms. The height assigned to fluvial landforms in all study reaches was used as a basis for fluvial landform classification. First, the heights of all landforms from all cross sections and study reaches were plotted as a frequency histogram and a cumulative frequency curve. Second, boundaries between fluvial landform classes were visually assigned at natural data gaps in the histogram or slope breaks along the cumulative frequency curve. Landform classes then were compared to hydrologic and river ice-level data to speculate on the nature of their formation.

\section{Bed Sediment}

The bed of the Niobrara River within the study reaches was typically observed to be bedrock overlain by a veneer of sand. The veneer of sand varied in thickness from tenths of an inch to several feet; where there was no sand, undulating and rilled bedrock was dominant with sparse pockets of fine gravel, which appeared to be bedrock disintegrating in-situ. The bed also contained infrequent and isolated boulders, which were suspected to have been rafted or transported into the reaches by winter ice jams. For the purpose of characterizing the particle sizes on the bed that may be in transport during the ice-off season, bed-material sampling was restricted to the veneers and patches of fine sediment.

Bed sediment in the study reaches was sampled in November and September of water year 2008 using a BMH-53 piston sampler (Edwards and Glysson, 1999). At all but the Crooked study reach, samples of bed material were obtained for the alluvial parts of the upstream and downstream cross sections by wading across the channel, driving the BMH-53 into the bed of the river, covering the base of the sampler, removing the cylinder, and placing the sample into a plastic sample bag. At the Crooked study reach, alluvial bed material generally was limited to isolated, vegetated sand dunes surrounded by bedrock; in this case, bed-material sampling was limited to subsamples of several of the dunes across the length of the reach. All bed-material samples were analyzed for grain-size distribution at the USGS Iowa National Sediment Laboratory, Iowa City, using methods described in Guy (1969). 
Hydraulics, Hydraulic Geometry, and Bed Adjustment

Discharge measurements were made to investigate channel and hydraulic adjustment processes within the study reaches. Discharge measurements were made over a range of discharge magnitudes during water years 2008 and part of 2009 (fig. 10) by NGPC personnel (S. Schainost, Nebraska Game and Parks Commission, unpublished data, 2008), in collaboration with the USGS. Cross sections 1 and 4 (most upstream and downstream, respectively) were used as the locations for discharge measurements at each study reach, except at Crooked, where cross sections 1 and 3 were used. Measurements were made at multiple sections along the cross section in an attempt to capture no more than 5 to 10 percent of the total discharge within any single increment (Rantz and others, 1982). Measurements primarily were made by wading the channel; nonwadeable sections were measured by suspending a velocity meter from a canoe tethered to a cable that spanned the channel cross section. Although the alteration of the local hydraulic field by the canoe could have affected measured velocities, direct comparison of velocity measurements made from the canoe with those made at the same location by wading indicated that the canoe had no detectible effect on local flow velocities when the instrument was placed an arm's length away from the side of the canoe. Additionally, at least one of the cross sections was wadeable, except during the highest flows, such that a quality-assurance comparison of discharge magnitudes across both methods could be made. All discharge measurements made on the same day within the same reach were within 10 percent of each other, and the majority of measurements were within 5 percent of each other. Measurements of water-surface slope also were made during the discharge measurements using RTK-GPS, auto-level, or total-station survey instruments.

Hydraulic geometry relations were developed for each of the study reaches using the field measurements of channel discharge. The relations were developed using methods

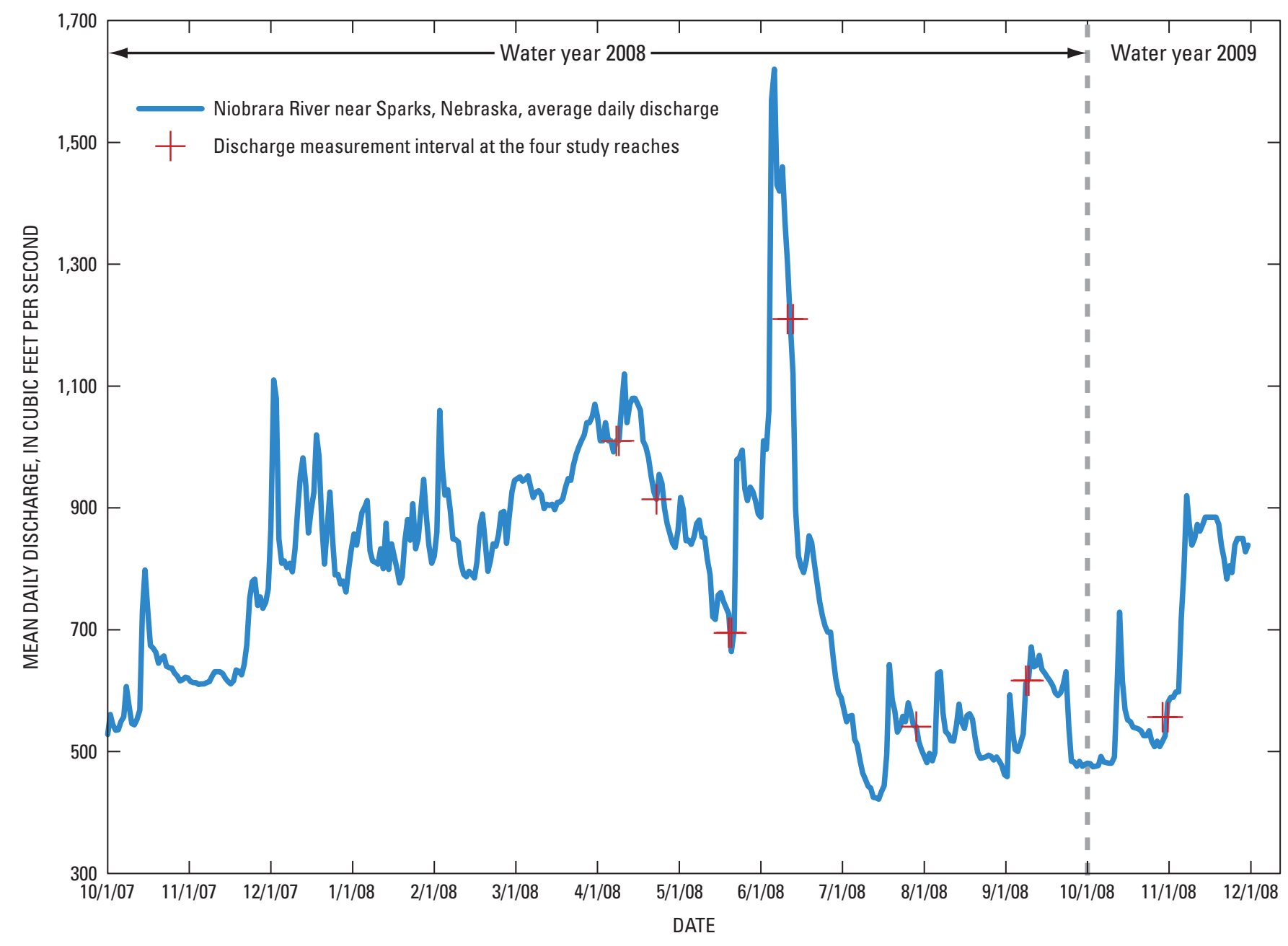

Figure 10. Mean daily discharge of the Niobrara River near Sparks, Nebraska, for the study period 0ctober 1, 2007, to November 30, 2008, showing reach-scale discharge measurement time periods. 
outlined by Leopold and Maddock (1953), using the notation of equations 1 through 3 described in the Hydraulic Geometry of the Niobrara River section of this report. The at-a-station relations in the linear form of the power functions (equations 1 through 3) were developed using ordinary leastsquares (OLS) regression of data pairs from the hydrologic technician's measurement notes. In all cases, the discharge calculated from the measurement was the independent variable (Q), and the dependent variable was the channel-top width $(w)$, the average channel depth $(d$, wetted area divided by top width), or average channel velocity ( $v$, discharge divided by wetted area). The OLS regression-line slope value (exponent), regression-line intercept value (coefficient), probability values (p-values), and coefficients of determination (COD) for all at-a-station hydraulic geometry relations were estimated using standard statistical tools in Excel ${ }^{\circledR}$, Microsoft Corp, Redmond, Wash. OLS regression-slope values were tested for statistical significance at the 90-percent confidence level; p-values less than 0.10 were interpreted to indicate that the slope coefficient estimated for the at-a-station hydraulic geometry relation was significantly different than zero. The COD, which indicates the fraction of the variance in the dependent variable explained by the regression model, was used as a secondary indicator of model goodness-of-fit.
At the reach scale, water depth and current velocity interact in a complex feedback with the channel bed, bank geometry, and erodibility as well as with the deformation and configuration of bedforms such as ripples, dunes, and bars (Leopold and others, 1964; Knighton, 1998). Field observations in the study reaches indicated that bedrock was very shallow or, in the case of the Crooked reach, the dominant bed material. However, the bed at the Sunny Brook, Muleshoe, and Rock Barn study reaches had substantial coverage by fine sediment, indicating bed deformation and scour were feasible. To further investigate the nature of channel hydraulic adjustments to changing discharges in the study reaches, the channel geometry and discharge measurement data were used to calculate additional hydraulic and channel topographic parameters. Mean boundary shear stress, mean boundary roughness (Manning's roughness coefficient, also known as Manning's $n$ ), and unit stream power were calculated as measures of flow force, resistance, and energy expenditure, respectively (table 8 ). Froude number was calculated as a measure of flow state (quiescent or rapid). Reference bed elevation was used as a measure of channel bed scour and fill behavior over the study period (table 8). Reference bed elevation was calculated only for those discharge measurements that could be referenced to a common vertical datum within each reach.

Table 8. Hydraulic parameters used to characterize flow and adjustment in Niobrara River study reaches.

$[\gamma$, specific weight of water (62 pounds per cubic foot); R, hydraulic radius of wetted channel calculated as the area of channel divided by wetted perimeter (feet); S, slope of the water surface (dimensionless); $v$, mean velocity of water in the channel (feet per second); $Q$, water discharge in the river channel (cubic feet per second); w, top width of the water surface of the wetted channel (feet); g, gravitational constant (32.174 feet per second squared); d, average depth of water (feet)]

\begin{tabular}{|c|c|c|c|}
\hline Parameter name & Symbol & Equation & Explanation \\
\hline Mean boundary shear stress & $\tau$ & $\tau=\gamma \mathrm{RS}$ & $\begin{array}{l}\text { Measure of flow force exerted on the boundary of the river channel, } \\
\text { expressed in pound-force per square foot. }\end{array}$ \\
\hline Mean boundary roughness & $\mathrm{n}$ & $\mathrm{n}=\left(1.486 * \mathrm{R}^{2 / 3 *} \mathrm{~S}^{1 / 2}\right) / \mathrm{v}$ & $\begin{array}{l}\text { Manning boundary roughness coefficient. Measure of flow } \\
\text { resistance. }\end{array}$ \\
\hline Froude number & $\mathrm{F}$ & $\mathrm{F}=\mathrm{v} /(\mathrm{gd})^{1 / 2}$ & $\begin{array}{l}\text { Ratio of inertial to gravitational forces; dimensionless. Used as a } \\
\text { measure of flow regime, upper or lower (F above or below } 1 \text {, } \\
\text { respectively). }\end{array}$ \\
\hline
\end{tabular}




\section{Hydraulic Microhabitats}

Discharge data from each of the study reaches also were used to investigate the range of available hydraulic microhabitats within each reach using the hydraulic microhabitat calculator of Ginting and Zelt (2008). Because a limited range of discharges was measured, hydraulic microhabitat distributions for all of the discharge frequency categories used in the basin-scale analysis could not be analyzed. In particular, no discharges below the 90-percent exceedance (lower-decile) flow were measured. Instead, the lowest available measured discharge at each study reach was analyzed for comparison with higher discharges. At the Crooked study reach, no high flow (upper-decile) discharge measurements were obtained during the study period. Because the study reaches are not located at bridges, the analysis was used as a measure of difference in hydraulic microhabitats in more natural, less engineered river reaches.

\section{Hydrogeomorphic Segments and Hydraulic Microhabitats}

Statistical analysis of hydrogeomorphic segments resulted in a reduction in the number of segments from 36 to 25 by merging adjacent segments which were identified as having identical combinations of element classes. The physical and hydraulic diversity of the Niobrara River is reflected in the presentation of longitudinal hydrogeomorphic characteristics and the hydraulic microhabitat distributions among differing fluvial geomorphic provinces. Data from study reaches in the Niobrara National Scenic River indicate a host of hydrogeomorphic processes are acting on the river including two types of flooding processes, downstream coarsening of bed material, and a two-mode hydraulic regime.

\section{Basin-Scale Results}

\section{Statistical Analysis of Hydrogeomorphic Segments}

Table 9 presents the results of the multiple comparison analysis (MCA) for the ANOVA models for each of the hydrogeomorphic variables associated with the four descriptive geomorphic elements (table 3). All variables successfully distinguished the total number of classes (table 9) for the valley confinement and channel-planview pattern descriptive elements. However, in the case of channel-planview pattern, only the comparison between classes 2 and 3 (sinuous and highly sinuous, respectively) was possible, because only two of the three possible classes actually were used from the classification proposed by Alexander and others (2009).

Ninetieth-percentile unit stream power (SP_90), which is a function of streamflow and channel slope, was surprisingly the least powerful of the variables across classes, only distinguishing between the maximum possible numbers of classes in the valley confinement geomorphic element. Although many of the variables were able to distinguish between all possible classes, not all variables added additional information to the discriminant function (table 9). For example, in the case of channel-planview pattern, only two of the seven variables were used to build the discriminant function ultimately used to classify each sampling point.

Overall classification error rates in the discriminant models varied from 23 to 29 percent among descriptive geomorphic elements, with error rates among individual classes within the elements having a much wider range of 2 to 60 percent (table 10). Two of the classes, class 2 of valley confinement (phase-restricted) and class 3 of bar configuration (braided bars), returned error rates of nearly 60 percent. In both cases, the high error rate was associated with a class that would have been expected to be difficult to distinguish from another class. For valley confinement, most of the classification error of class 2 (phase-restricted) was from points being classified as class 3 (width-restricted); both class 2 and class 3 were presented as "restricted" valley settings previously (Alexander and others, 2009). For bar configuration, most of the classification error in class 3 (braided bar) was associated with assignment as class 1 (alternate bar), a distinction that is difficult because of the co-existence of both bar types within many segments. Moreover, the prediction of bar types in general is a discharge-dependent exercise (Bridge, 2003). Although some of the reclassification rates for individual element classes were relatively high, the p-values associated with the Wilks' lambda test statistic for multivariate equality of means indicate that the probability of the means of the element classes being equal is extremely low (table 10).

The statistical analysis of hydrogeomorphic segments resulted in reclassification rates of 3 to 28 percent of the segments for the four descriptive geomorphic elements (table 11). The largest rates of class reassignments were for the valley confinement (28 percent) and channel-bar configuration (25 percent) categories. Sinuosity and channel-width variation had relatively minor shifts of 3 and 14 percent, respectively, among segments. The reassignment of classes by the discriminant analysis resulted in a reduction from 36 to 25 total hydrogeomorphic segments because several adjoining segments shared the same ultimate class assignments among individual descriptive geomorphic elements (fig. 11). Virtually all of the segment mergers were in the CRB fluvial geomorphic province, where reassignment of valley confinement and width variation classes alone resulted in numerous segment mergers (table 12). Class reassignments and merger of hydrogeomorphic segments did not result in changes to the statistical modal class for any descriptive geomorphic element relative to those reported previously (Alexander and others, 2009) for the study area (table 12). The most frequent conditions (modal classes) among hydrogeomorphic segments are a width-restricted valley confinement condition, sinuousplanview pattern, irregular channel width, and an alternate 


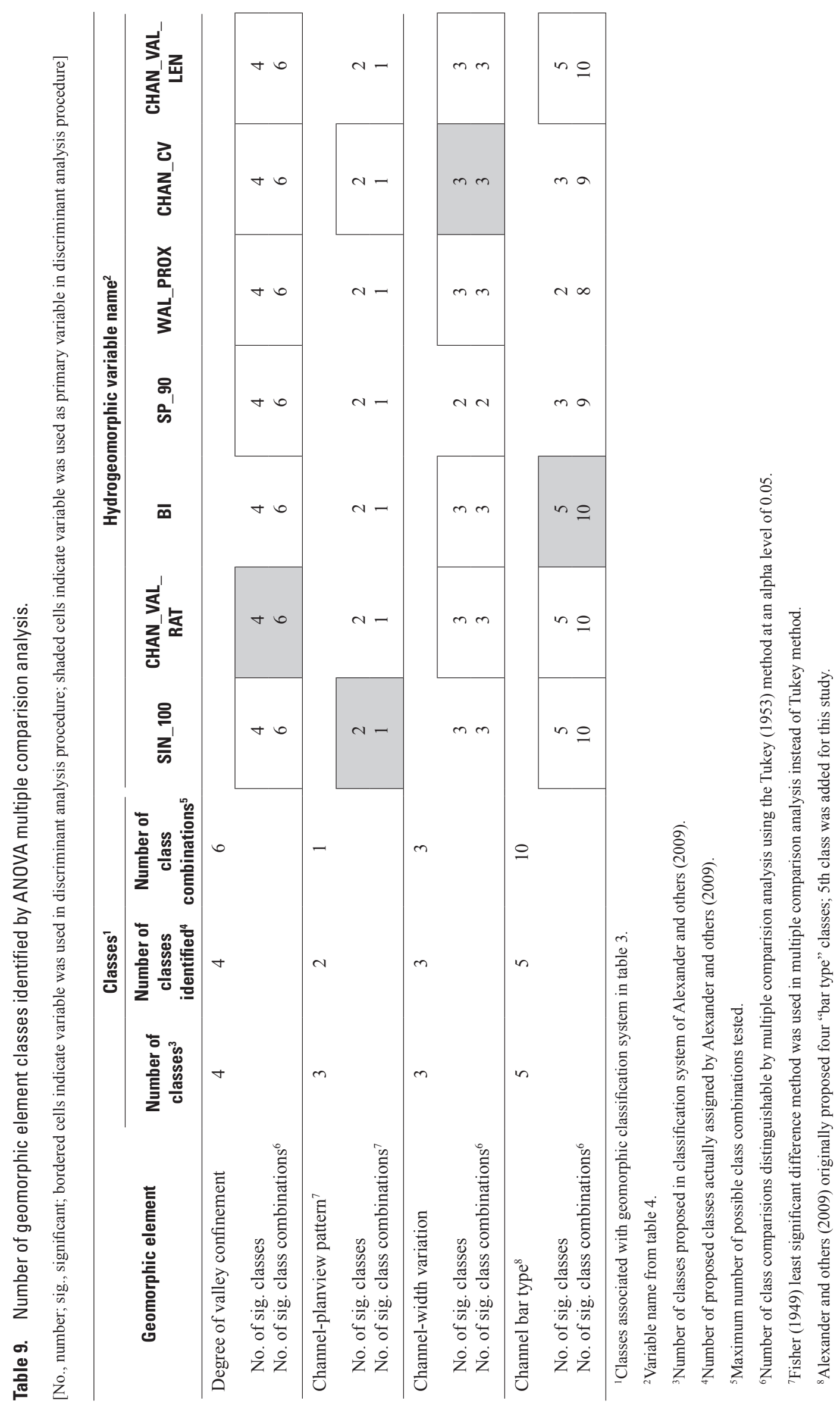


Table 10. Cross-validation results from discriminant analyses of sampling points of the Niobrara River, Nebraska, by geomorphic element class.

[NA, no class available or assigned for geomorphic element; classification error rate is defined as the percentage of sampling points reassigned to a different geomorphic element class by the discriminant function; overall, statistics for the classification performance across all classes; <, less than]

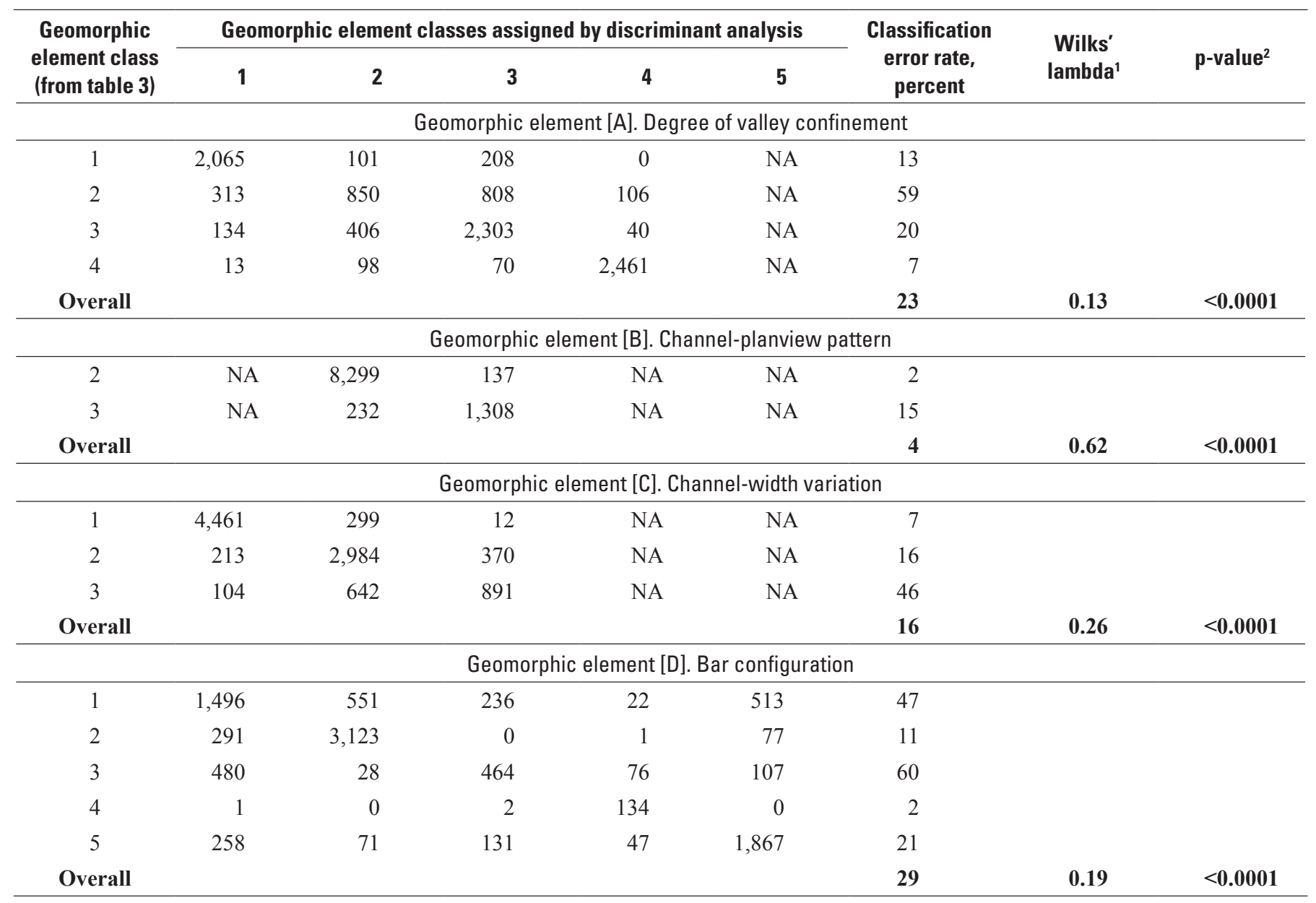

${ }^{1}$ Wilks' lambda value for test of multivariate equality of means between geomorphic element classes.

${ }^{2}$ Probability of obtaining indicated test statistic when class mean values are the same.

bar configuration. The class reassignments and segment mergers did, however, result in changes to the dominant classes per unit length of river, which are now the same as the modal classes. The braided bar class was eliminated from all segments within the CRB province, resulting in a switch to alternate bars being the dominant bar configuration per unit stream length in the study area. The open valley class was eliminated from valley-confinement conditions within the $\mathrm{CRB}$ province but remained the dominant valley-confinement condition in the MB.

The characteristics of those reaches with assignment changes in at least one of the geomorphic element categories were spot-checked to ensure that the new classification did not contradict those that were visible and unambiguous in the color aerial photographs. Although much of the class reassignment and segment merging occurred because of physical characteristics that were difficult to objectively assess within a broader physical context, some class reassignments were obvious errors. Specifically, the discriminant analysis reassigned bar configuration classes in segments 7 and 8 (table 12) that were in deviation from those visible in aerial photographs, and from the authors' observations in the field. Segment 8, which includes the reach immediately upstream from Cornell Dam, was reassigned from a "braided" bar condition to a "bedrock" bar condition by the discriminant analysis. Although segment 8 is confined by bedrock laterally, the bar configuration is dominated by braided bars at least partially because of the backwater effect from Cornell Dam. The bed of the river in segment 7, which includes the segment immediately downstream from Cornell Dam, was noted during field visits by the authors to be dominated by bedrock, though alternate bars do occur. 
Table 11. Distribution of classes assigned using discriminant analyses to sampling points within each hydrogeomorphic segment defined by Alexander and others (2009) for the Niobrara River, Nebraska.

[Orig., original; \%, percent; shaded cells indicate change from original class]

\begin{tabular}{|c|c|c|c|c|c|c|c|c|c|c|c|}
\hline \multirow{3}{*}{$\begin{array}{c}\text { Segment } \\
\text { number }\end{array}$} & \multirow{3}{*}{$\begin{array}{l}\text { Sample } \\
\text { size }\end{array}$} & \multicolumn{6}{|c|}{ Geormorphic element [A]. Degree of valley confinement } & \multicolumn{4}{|c|}{ Geomorphic element [B]. Channel-planview pattern } \\
\hline & & \multirow{2}{*}{$\begin{array}{l}\text { Orig. } \\
\text { class }\end{array}$} & \multicolumn{4}{|c|}{ Classes } & \multirow{2}{*}{$\begin{array}{l}\text { New } \\
\text { class }\end{array}$} & \multirow{2}{*}{$\begin{array}{l}\text { Orig. } \\
\text { class }\end{array}$} & \multicolumn{2}{|c|}{ Classes } & \multirow{2}{*}{$\begin{array}{l}\text { New } \\
\text { class }\end{array}$} \\
\hline & & & 1 & 2 & 3 & 4 & & & 2 & 3 & \\
\hline \multicolumn{12}{|c|}{ Braided Bottoms fluvial geomorphic province } \\
\hline 1 & 17 & 3 & 12 & 5 & 0 & 0 & 1 & 2 & 17 & 0 & 2 \\
\hline 2 & 126 & 3 & 0 & 3 & 123 & 0 & 3 & 2 & 126 & 0 & 2 \\
\hline 3 & 31 & 3 & 0 & 0 & 31 & 0 & 3 & 2 & 31 & 0 & 2 \\
\hline 4 & 119 & 3 & 12 & 10 & 97 & 0 & 3 & 2 & 119 & 0 & 2 \\
\hline 5 & 271 & 3 & 4 & 15 & 252 & 0 & 3 & 2 & 271 & 0 & 2 \\
\hline 6 & 102 & 2 & 0 & 13 & 89 & 0 & 3 & 2 & 102 & 0 & 2 \\
\hline \multicolumn{12}{|c|}{ Canyons and Restricted Bottoms fluvial geomorphic province } \\
\hline 7 & 316 & 2 & 112 & 180 & 24 & 0 & 2 & 2 & 283 & 33 & 2 \\
\hline 8 & 597 & 1 & 563 & 23 & 11 & 0 & 1 & 2 & 597 & 0 & 2 \\
\hline 9 & 212 & 1 & 161 & 5 & 46 & 0 & 1 & 2 & 212 & 0 & 2 \\
\hline 10 & 107 & 3 & 14 & 9 & 84 & 0 & 3 & 2 & 107 & 0 & 2 \\
\hline 11 & 255 & 3 & 0 & 61 & 194 & 0 & 3 & 2 & 255 & 0 & 2 \\
\hline 12 & 146 & 3 & 0 & 65 & 81 & 0 & 3 & 2 & 146 & 0 & 2 \\
\hline 13 & 248 & 2 & 0 & 7 & 241 & 0 & 3 & 2 & 248 & 0 & 2 \\
\hline 14 & 169 & 3 & 1 & 18 & 150 & 0 & 3 & 2 & 169 & 0 & 2 \\
\hline 15 & 210 & 2 & 76 & 91 & 43 & 0 & 2 & 2 & 210 & 0 & 2 \\
\hline 16 & 253 & 3 & 2 & 89 & 162 & 0 & 3 & 2 & 253 & 0 & 2 \\
\hline 17 & 460 & 2 & 97 & 245 & 118 & 0 & 2 & 2 & 460 & 0 & 2 \\
\hline 18 & 184 & 1 & 143 & 3 & 38 & 0 & 1 & 2 & 154 & 30 & 2 \\
\hline 19 & 403 & 3 & 4 & 29 & 358 & 12 & 3 & 2 & 403 & 0 & 2 \\
\hline 20 & 267 & 2 & 16 & 71 & 180 & 0 & 3 & 2 & 267 & 0 & 2 \\
\hline 21 & 90 & 4 & 12 & 58 & 1 & 19 & 2 & 3 & 90 & 0 & 2 \\
\hline 22 & 53 & 3 & 50 & 3 & 0 & 0 & 1 & 2 & 37 & 16 & 2 \\
\hline 23 & 929 & 1 & 917 & 12 & 0 & 0 & 1 & 3 & 73 & 856 & 3 \\
\hline 24 & 99 & 3 & 37 & 32 & 30 & 0 & 1 & 2 & 99 & 0 & 2 \\
\hline 25 & 352 & 1 & 259 & 23 & 70 & 0 & 1 & 2 & 350 & 2 & 2 \\
\hline 26 & 231 & 3 & 2 & 4 & 222 & 3 & 3 & 2 & 231 & 0 & 2 \\
\hline 27 & 100 & 1 & 11 & 38 & 51 & 0 & 3 & 2 & 100 & 0 & 2 \\
\hline 28 & 186 & 3 & 0 & 2 & 175 & 9 & 3 & 2 & 186 & 0 & 2 \\
\hline 29 & 165 & 2 & 13 & 9 & 131 & 12 & 3 & 2 & 165 & 0 & 2 \\
\hline 30 & 170 & 3 & 0 & 23 & 130 & 17 & 3 & 2 & 170 & 0 & 2 \\
\hline 31 & 74 & 4 & 0 & 7 & 46 & 21 & 3 & 2 & 74 & 0 & 2 \\
\hline 32 & 246 & 3 & 0 & 17 & 229 & 0 & 3 & 2 & 246 & 0 & 2 \\
\hline 33 & 309 & 2 & 0 & 210 & 8 & 91 & 2 & 2 & 309 & 0 & 2 \\
\hline \multicolumn{12}{|c|}{ Meandering Bottoms fluvial geomorphic province } \\
\hline 34 & 1,689 & 4 & 0 & 36 & 23 & 1,630 & 4 & 2 & 1,671 & 18 & 2 \\
\hline 35 & 521 & 4 & 0 & 0 & 0 & 521 & 4 & 3 & 68 & 453 & 3 \\
\hline 36 & 269 & 4 & 0 & 0 & 0 & 269 & 4 & 2 & 232 & 37 & 2 \\
\hline
\end{tabular}


Table 11. Distribution of classes assigned using discriminant analyses to sampling points within each hydrogeomorphic segment defined by Alexander and others (2009) for the Niobrara River, Nebraska.-Continued

[Orig., original; \%, percent; shaded cells indicate change from original class]

\begin{tabular}{|c|c|c|c|c|c|c|c|c|c|c|c|c|c|}
\hline \multirow{3}{*}{$\begin{array}{l}\text { Segment } \\
\text { number }\end{array}$} & \multirow{3}{*}{$\begin{array}{l}\text { Sample } \\
\text { size }\end{array}$} & \multicolumn{5}{|c|}{ Geomorphic element [C]. Channel-width variation } & \multicolumn{7}{|c|}{ Geomorphic element [D]. Channel-bar configuration } \\
\hline & & \multirow{2}{*}{$\begin{array}{l}\text { Orig. } \\
\text { class }\end{array}$} & \multicolumn{3}{|c|}{ Classes } & \multirow{2}{*}{$\begin{array}{l}\text { New } \\
\text { class }\end{array}$} & \multirow{2}{*}{$\begin{array}{l}\text { Orig. } \\
\text { Class }\end{array}$} & \multicolumn{5}{|c|}{ Classes } & \multirow{2}{*}{$\begin{array}{l}\text { New } \\
\text { class }\end{array}$} \\
\hline & & & 1 & 2 & 3 & & & 1 & 2 & 3 & 4 & 5 & \\
\hline \multicolumn{14}{|c|}{ Braided Bottoms fluvial geomorphic province } \\
\hline 1 & 17 & 3 & 0 & 3 & 14 & 3 & 4 & 0 & 0 & 0 & 17 & 0 & 4 \\
\hline 2 & 126 & 3 & 0 & 15 & 111 & 3 & 3 & 16 & 0 & 84 & 26 & 0 & 3 \\
\hline 3 & 31 & 2 & 0 & 7 & 24 & 3 & 1 & 16 & 0 & 15 & 0 & 0 & 1 \\
\hline 4 & 119 & 3 & 0 & 13 & 106 & 3 & 4 & 2 & 0 & 6 & 111 & 0 & 4 \\
\hline 5 & 271 & 3 & 0 & 43 & 228 & 3 & 3 & 20 & 0 & 240 & 11 & 0 & 3 \\
\hline 6 & 102 & 3 & 0 & 41 & 61 & 3 & 3 & 46 & 1 & 55 & 0 & 0 & 3 \\
\hline \multicolumn{14}{|c|}{ Canyons and Restricted Bottoms fluvial geomorphic province } \\
\hline 7 & 316 & 1 & 278 & 38 & 0 & 1 & 2 & 168 & 98 & 0 & 0 & 50 & 1 \\
\hline 8 & 597 & 1 & 550 & 47 & 0 & 1 & 5 & 353 & 1 & 45 & 0 & 198 & 1 \\
\hline 9 & 212 & 2 & 0 & 201 & 11 & 2 & 3 & 49 & 0 & 74 & 0 & 89 & 5 \\
\hline 10 & 107 & 2 & 0 & 76 & 31 & 2 & 3 & 72 & 0 & 35 & 0 & 0 & 1 \\
\hline 11 & 255 & 2 & 0 & 213 & 42 & 2 & 1 & 129 & 77 & 20 & 14 & 15 & 1 \\
\hline 12 & 146 & 3 & 0 & 82 & 64 & 2 & 3 & 112 & 0 & 14 & 20 & 0 & 1 \\
\hline 13 & 248 & 2 & 0 & 234 & 14 & 2 & 1 & 181 & 48 & 19 & 0 & 0 & 1 \\
\hline 14 & 169 & 2 & 24 & 145 & 0 & 2 & 1 & 60 & 109 & 0 & 0 & 0 & 2 \\
\hline 15 & 210 & 2 & 4 & 203 & 3 & 2 & 1 & 146 & 13 & 17 & 0 & 34 & 1 \\
\hline 16 & 253 & 2 & 0 & 210 & 43 & 2 & 1 & 209 & 22 & 22 & 0 & 0 & 1 \\
\hline 17 & 460 & 2 & 0 & 439 & 21 & 2 & 1 & 351 & 42 & 36 & 0 & 31 & 1 \\
\hline 18 & 184 & 2 & 49 & 127 & 8 & 2 & 1 & 26 & 0 & 28 & 0 & 130 & 5 \\
\hline 19 & 403 & 3 & 111 & 226 & 66 & 2 & 3 & 346 & 26 & 29 & 0 & 2 & 1 \\
\hline 20 & 267 & 2 & 0 & 264 & 3 & 2 & 1 & 124 & 46 & 37 & 0 & 60 & 1 \\
\hline 21 & 90 & 1 & 80 & 10 & 0 & 1 & 2 & 0 & 88 & 0 & 0 & 2 & 2 \\
\hline 22 & 53 & 1 & 53 & 0 & 0 & 1 & 2 & 3 & 15 & 0 & 0 & 35 & 5 \\
\hline 23 & 929 & 1 & 851 & 62 & 16 & 1 & 5 & 23 & 75 & 0 & 7 & 824 & 5 \\
\hline 24 & 99 & 2 & 34 & 50 & 15 & 2 & 1 & 75 & 5 & 0 & 3 & 16 & 1 \\
\hline 25 & 352 & 3 & 23 & 186 & 143 & 2 & 1 & 229 & 2 & 46 & 0 & 75 & 1 \\
\hline 26 & 231 & 2 & 17 & 179 & 35 & 2 & 1 & 182 & 40 & 9 & 0 & 0 & 1 \\
\hline 27 & 100 & 3 & 0 & 98 & 2 & 2 & 1 & 93 & 3 & 4 & 0 & 0 & 1 \\
\hline 28 & 186 & 2 & 3 & 165 & 18 & 2 & 1 & 160 & 16 & 10 & 0 & 0 & 1 \\
\hline 29 & 165 & 2 & 57 & 108 & 0 & 2 & 1 & 90 & 27 & 0 & 0 & 48 & 1 \\
\hline 30 & 170 & 2 & 40 & 122 & 8 & 2 & 1 & 116 & 53 & 1 & 0 & 0 & 1 \\
\hline 31 & 74 & 2 & 13 & 61 & 0 & 2 & 1 & 46 & 28 & 0 & 0 & 0 & 1 \\
\hline 32 & 246 & 2 & 4 & 242 & 0 & 2 & 2 & 111 & 135 & 0 & 0 & 0 & 2 \\
\hline 33 & 309 & 1 & 273 & 36 & 0 & 1 & 2 & 0 & 309 & 0 & 0 & 0 & 2 \\
\hline \multicolumn{14}{|c|}{ Meandering Bottoms fluvial geomorphic province } \\
\hline 34 & 1,689 & 1 & 1,575 & 114 & 0 & 1 & 2 & 0 & 1,689 & 0 & 0 & 0 & 2 \\
\hline 35 & 521 & 1 & 502 & 19 & 0 & 1 & 2 & 0 & 521 & 0 & 0 & 0 & 2 \\
\hline 36 & 269 & 1 & 269 & 0 & 0 & 1 & 2 & 0 & 269 & 0 & 0 & 0 & 2 \\
\hline
\end{tabular}



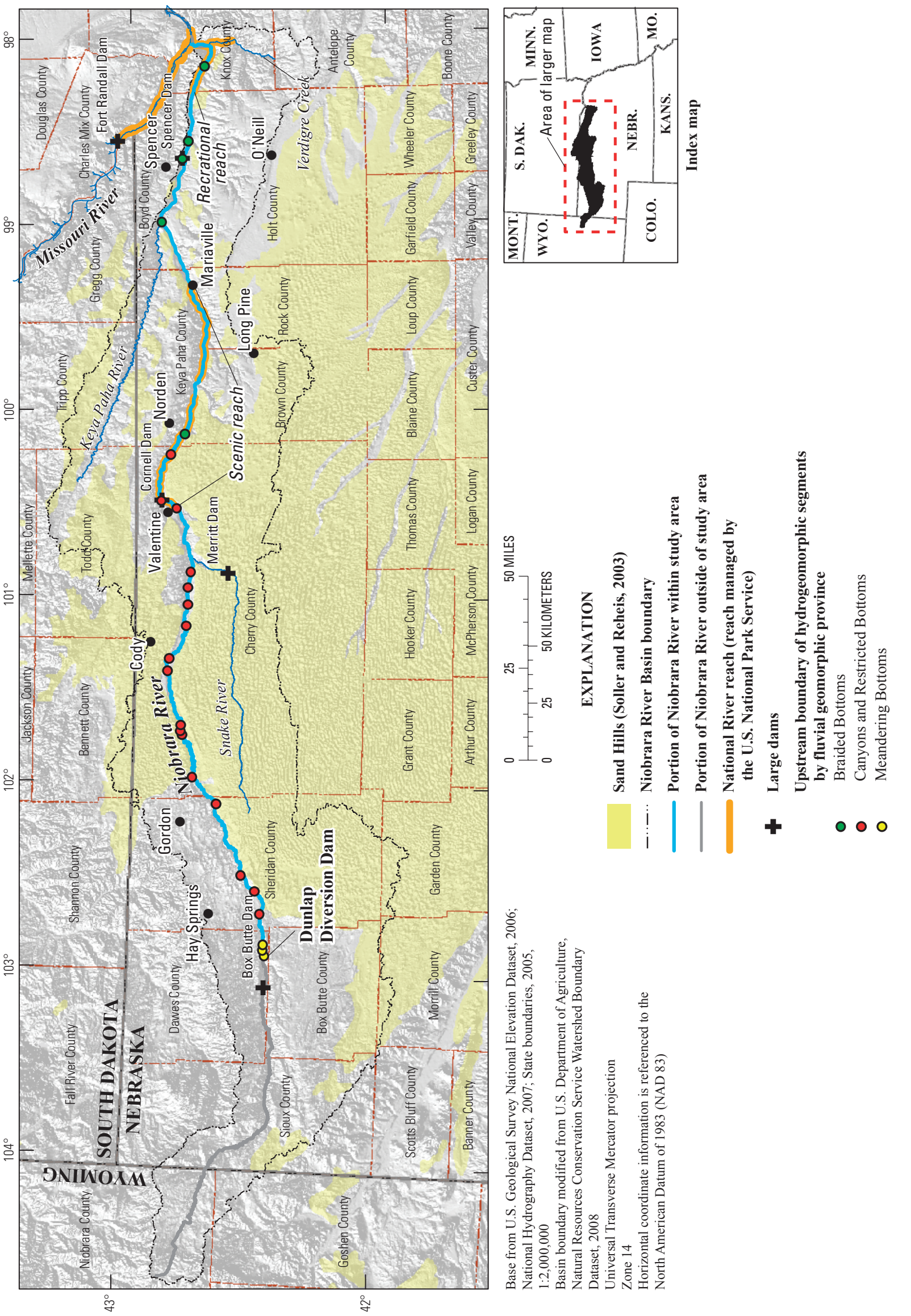

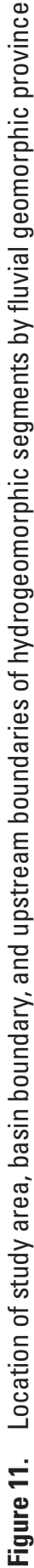




\section{Hydrogeomorphic Segments and Hydraulic Microhabitats of the Niobrara River, Nebraska}

Table 12. Hydrogeomorphic segments of the Niobrara River between Dunlap Diversion Dam and the Missouri River, Nebraska (modified from Alexander and others, 2009).

[River mile, miles upstream from Missouri River; S.A., percent of total length of Niobrara main stem channel in study area; values in () indicate class reassigned on basis of field observations; shaded cells indicate segment includes part of Niobrara National Scenic River]

\begin{tabular}{|c|c|c|c|c|c|c|}
\hline \multirow[b]{2}{*}{$\begin{array}{l}\text { Segment } \\
\text { number }\end{array}$} & \multirow[b]{2}{*}{$\begin{array}{l}\text { River } \\
\text { mile }\end{array}$} & \multirow[b]{2}{*}{$\begin{array}{l}\text { Percent of } \\
\text { S.A. length }\end{array}$} & \multicolumn{4}{|c|}{ Descriptive geomorphic elements and assigned condition classes } \\
\hline & & & $\begin{array}{c}{[\mathrm{A}]} \\
\text { Degree of valley } \\
\text { confinement }\end{array}$ & $\begin{array}{c}{[B]} \\
\text { Channel-planview } \\
\text { pattern }\end{array}$ & $\begin{array}{c}\text { [C] } \\
\text { Channel-width } \\
\text { variation }\end{array}$ & $\begin{array}{c}\text { [D] } \\
\text { Bar } \\
\text { configuration }\end{array}$ \\
\hline \multicolumn{7}{|c|}{ Braided Bottoms fluvial geomorphic province } \\
\hline 1 & 12 & 3.6 & 1 & 2 & 3 & 4 \\
\hline${ }^{1} 4$ & 60 & 6.2 & 3 & 2 & 3 & 4 \\
\hline 5 & 125 & 19.6 & 3 & 2 & 3 & 3 \\
\hline \multicolumn{7}{|c|}{ Canyons and Restricted Bottoms fluvial geomorphic province } \\
\hline 6 & 134 & 2.7 & 2 & 2 & 1 & 1 \\
\hline 10 & 182 & 1.4 & 3 & 2 & 2 & 2 \\
\hline 11 & 188 & 1.8 & 2 & 2 & 2 & 1 \\
\hline 12 & 195 & 2.1 & 3 & 2 & 2 & 1 \\
\hline 13 & 208 & 3.9 & 2 & 2 & 2 & 1 \\
\hline 14 & 213 & 1.6 & 1 & 2 & 2 & 5 \\
\hline 15 & 232 & 5.6 & 3 & 2 & 2 & 1 \\
\hline 16 & 234 & 0.8 & 2 & 2 & 1 & 2 \\
\hline 17 & 236 & 0.4 & 1 & 2 & 1 & 5 \\
\hline 18 & 262 & 7.8 & 1 & 3 & 1 & 5 \\
\hline 23 & 326 & 3.2 & 4 & 2 & 1 & 2 \\
\hline 24 & 330 & 1.0 & 4 & 3 & 1 & 2 \\
\hline \multirow[t]{5}{*}{25} & 332 & .6 & 4 & 2 & 1 & 2 \\
\hline & & & \multicolumn{4}{|c|}{ Mode $^{2}$} \\
\hline & & & 3 & 2 & 2 & 1 \\
\hline & & & \multicolumn{4}{|c|}{ Per unit stream length ${ }^{3}$} \\
\hline & & & 3 & 2 & 2 & 1 \\
\hline
\end{tabular}

${ }^{1}$ Reach includes backwater of mainstem dam.

${ }^{2}$ Mode refers to the most frequently occuring condition class among segments.

${ }^{3}$ Per unit length refers to the condition class that is most frequent when considering total channel length within the study area. 


\section{Hydrogeomorphic Characteristics of the Niobrara River}

The Niobrara River in the study area flows through a diversity of fluvial geomorphic settings in its traverse across northern Nebraska. The most distinct differences are among the settings found in the three fluvial geomorphic provinces. The river channel increases in width within the study area from a median of approximately $30 \mathrm{ft}$ in the MB province to a median of over a 1,000 ft near the Missouri River (table 13). With the exception of the MB fluvial geomorphic province, valley width and channel width increase and decrease in general synchronicity (fig. 12), indicating that bedrock geology, in addition to hydrology, acts as an important control in Niobrara channel form. This is especially the case in the CRB fluvial geomorphic province, where gains in river discharge do not necessarily translate into gains in channel width because valley width is limiting (fig. 12). In the MB province, river discharge magnitudes are low, the median channel width varies from 20 to $30 \mathrm{ft}$, but the valley is over 3,000 ft wide in places, and exerts little control on the channel-planview pattern. Within the CRB province, the river flows over a diversity of geologic formations, and the valley and river narrow and expand in approximate synchronicity, in some cases forming entrenched canyons, with steep channel slopes, yet highly sinuous channel patterns. In the BB fluvial geomorphic province, the river primarily flows over Cretaceous Pierre Shale (fig. 2), the valley and channel are persistently wide, and the channel slope is generally uniform (fig. 12).

The existence of vegetated islands and consequent multithread channel environments, indicated by a higher braided index, mostly coincided with reaches having gentler slopes and less unit stream power (figs. $12 B$ and 12D). In general, island environments are most sparse or do not exist in reaches where the channel slope is greater than 0.15 percent. Within the MB province, stream power is relatively low, but channel slope is persistently steeper than 0.15 percent, and no islands were identified in the GIS. Within the CRB province, channel slope is highly variable, braided index rarely exceeds 2 , and islands are concentrated mainly in the reaches having mild slopes and lower unit stream power (figs. $12 B$ and $12 D$ ). In the $\mathrm{BB}$ province, braided index was, on average, higher than in the upstream provinces, but islands are mainly concentrated in the delta reach near the mouth at the Missouri River and in the reach immediately upstream from Spencer Dam (fig. 12B). Within these reaches, river slope and unit stream power are lower, on average, than much of the study area, and the river is persistently anastomosing. The combination of lower channel slope and unit stream power are typical characteristics of anastomosing rivers (Smith and Putnam, 1980; Knighton and Nanson, 1993); however, the higher braided index values for these reaches likely are affected primarily by the backwater effects from Spencer Dam and sedimentation at the delta at the confluence with the Missouri River. The higher braided index in the lower slope regions of the river seemingly contradicts the statistical models proposed by Leopold and Wolman (1957), which indicates that braided rivers typically have steeper slopes than straight or meandering rivers. However, much of the Niobrara could not be considered "fully" alluvial because of the considerable influence of bedrock on channel slope and planform characteristics (fig. 2). Therefore, much of the CRB province and parts of the $\mathrm{BB}$ province do not meet the primary assumption of a channel with an adjustable or "mobile" boundary to qualify for comparison with such models. Furthermore, the segments with the highest braided index values are functionally most similar to deltaic environments, where deposition and avulsion, as opposed to sediment transfer, are the primary fluvial processes.

Longitudinal hydrology curves indicate that the flow of the Niobrara River likely is dominated by groundwater as far downstream as Norden (fig. 12C). Upstream from Norden, the mean daily, median, and 90th-percentile discharge curves have approximately the same longitudinal slope and have only minor differences in overall magnitude. Between the Snake River confluence and Norden, all three hydrologic curves begin to diverge, indicating the hydrologic regime becomes more variable as the river flows out of the CRB and into the BB province. Flood-frequency values published by Soenksen and others (1999) share a similar pattern with 2- and 5 -year return-flood values increasing only slightly upstream from Norden, but substantially increasing downstream from Norden. The effect of groundwater also is visible by comparing longitudinal increases in drainage area with the longitudinal hydrology curves (fig. 12C). Although many of the upper study area tributary streams were ungaged or not included in the analysis, the graph trace between main-stem streamflowgaging stations indicates that large increases in drainage area, such as those at Pine Creek (fig. 12C), do not correspond to proportional increases in main-stem discharge. This pattern persists until at least the Snake River confluence, where increases in drainage area begin to have proportional increases in flow (runoff).

Unit stream power values in the study area vary between 0 and almost 2 pounds per foot per second (fig. 12D). Within the MB province, unit stream power steadily increases as the Niobrara gains discharge from groundwater inflow, and the channel slope steepens. At the downstream end of the MB province, the channel slope decreases, and flow and channel width steadily increase, causing a drop in unit stream power values as the Niobrara transitions into the CRB province. The combination of steep slopes, a constrained channel width, and persistent flow within the CRB province results in unit stream power values that are between three and five times greater than those in less confined segments with comparable or greater discharges (table 13). Two reaches with relatively high unit stream power values in the study area are within two narrow canyon sections, an entrenched meandering-canyon reach (segment 18) and the canyon within the Scenic Reach (segment 7) (fig. 12D). Both of these segments were classified as having bedrock-dominated bed conditions (table 12). The higher unit stream power values and bedrock bed indicate 


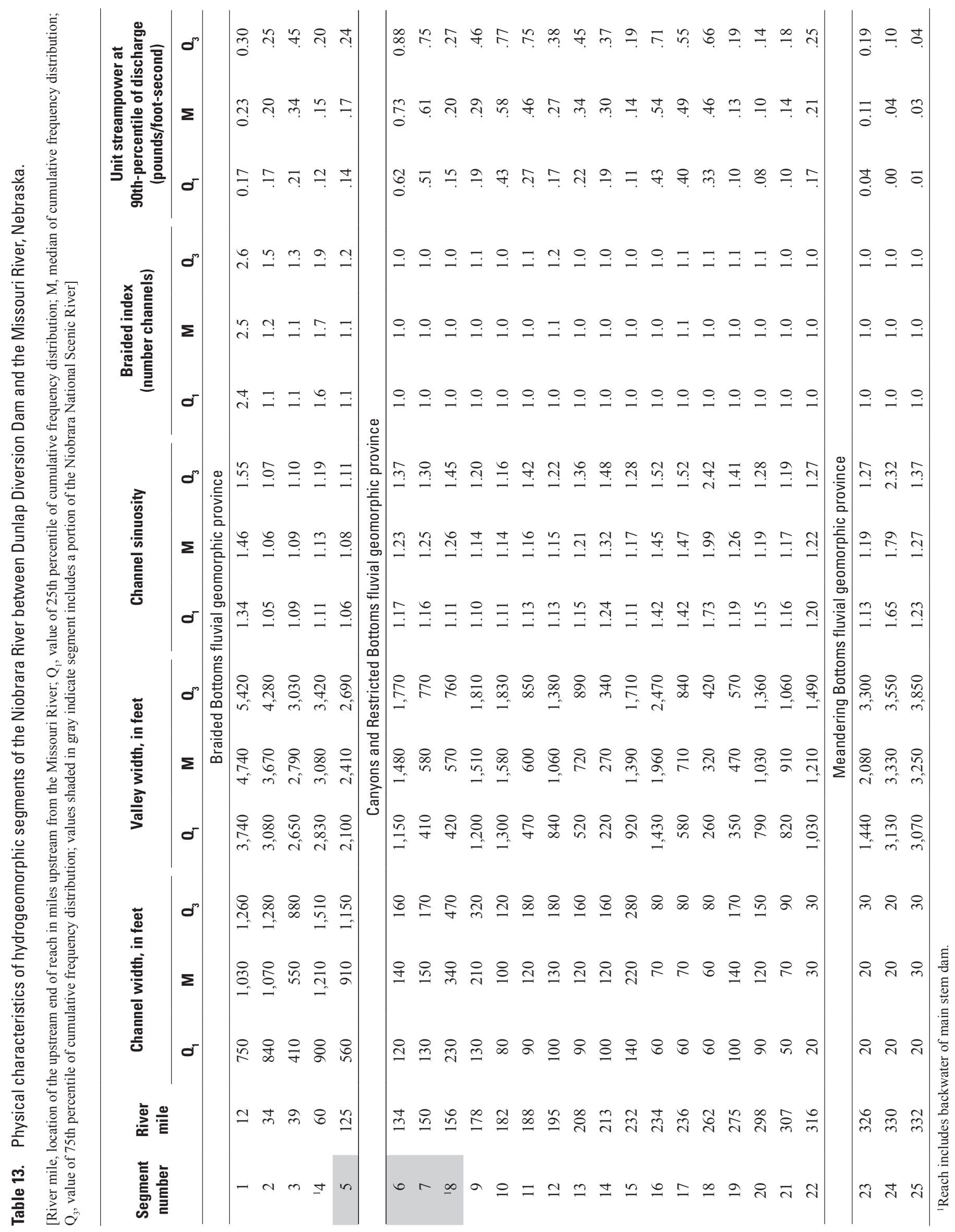


that these two segments likely transport the entire load of sediment delivered from upstream or originating within the reach annually. With the exception of segment 3 , which is affected by Spencer Dam, unit stream power values in the BB province generally are uniform. This consistency results from downstream increases in discharge that are offset by steady decreases in channel slope and steady increases in channel width downstream from Norden. Within segment 3, the reach immediately below Spencer Dam, the Niobrara River narrows abruptly, and the channel steepens, causing a consequent spike in unit stream power values (fig. 12D). The segment downstream from Spencer Dam is another reach that, although not classified as a bedrock-dominated bed, is known to have reaches that have shallow and or visible bedrock outcropping on the channel bed. The pre-dam morphology of the Niobrara River immediately below Spencer Dam was not investigated, and, therefore, whether Spencer Dam operations are the primary reason for channel steepening or morphologic change is inconclusive. However, the seasonal disruption of sediment loads in the Niobrara below Spencer Dam undoubtedly has some effect on overall channel morphology in this reach.

Channel sinuosity values in the study area (table 13) varied generally between 1 and 2.5 , but with locally higher values measured in the MB province and at the entrenched bedrock meanders of segment 18 in the CRB province (fig. 12E). Within segment 24 of the MB province, the Niobrara River has very little flow, and the channel has a two-phase meander pattern (lower amplitude and shorter wavelength pattern superimposed on a larger-scale meander pattern). Within segment 18 , the river has a highly sinuous pattern that is entrenched in bedrock, and the presence of rincons (abandoned bedrock meander bends) and the bedrock bed indicate that the river is cutting down through the bedrock at a relatively rapid rate. These two highly sinuous reaches likely have very different dominant fluvial processes. In the MB province, the highly sinuous planform is the result of channel meandering across the valley bottom, resulting in active flood plain destruction and deposition, and subsequent riparian forest recruitment that is in alignment with the overall channel pattern. In segment 18 , the highly sinuous pattern is entrenched, indicating that the lateral migration rate (meandering) is much slower than the rate of channel downcutting. The highly sinuous pattern of segment 18 is in this sense a relict form, and the flood plain is limited to production along a narrow strip, and likely home to a mature and diverse riparian forest, possibly similar to that found in the canyon segment of the Scenic Reach (segment 7). Channel sinuosity is lowest in the long, generally straight, braided reaches of the $\mathrm{BB}$ province. Channel sinuosity within the BB province is greatest near the delta, where the river makes a large turn toward the Missouri River, and the channel threads migrate around the abundant vegetated islands.

\section{Hydraulic Microhabitats of Differing Fluvial Geomorphic Provinces}

The differences in channel morphology and hydraulic geometries between fluvial geomorphic provinces are evident in the types, relative abundance, and response of hydraulic microhabitats to changing discharges. The four gaging stations chosen for hydraulic microhabitat analysis are distributed among three different fluvial geomorphic provinces (table 12); Hay Springs (Meandering Bottoms), Cody (Canyons and Restricted Bottoms), Sparks (Canyons and Restricted Bottoms), and Verdel (Braided Bottoms) streamflow-gaging stations are located in hydrogeomorphic segments 23,13 , 7 , and 2, respectively. In figure 13, lower-decile, medianquantile, and upper-decile discharges are defined as those exceeded 90, 25 to 75 , and 10 percent of all days during the period of record indicated for each gage by Alexander and others (2009). The hydraulic microhabitat availability was calculated as the average for two discharges (when available) within each exceedance category (table 14). At Hay Springs, the smaller channel and lower discharges result in the dominance of shallow and intermediate-depth hydraulic environments with the vast majority of hydraulic microhabitat restricted to shallow categories even during upper-decile discharges (fig. 13). Hydraulic microhabitat distributions and responses over the range of discharge frequencies analyzed are similar at the Cody and Sparks gaging stations. Over all ranges of discharge, intermediate-depth hydraulic conditions, particularly intermediate-swift, dominate at both gages; as discharge increases, intermediate-depth hydraulic conditions are mainly exchanged for deeper hydraulic conditions (table 14). Hydraulic microhabitat conditions are most diverse in the wide, braided reach of Verdel, with most hydraulic microhabitat categories present over the entire range of discharges analyzed. During lower-decile flows, the channel at Verdel is dominated by shallow hydraulic conditions. As discharge increases to upper-decile flow conditions, hydraulic microhabitats are more evenly distributed, with no hydraulic habitat category covering more than 25 percent of the total channel width (fig. 13C).

The calculated differences in hydraulic microhabitat distributions, abundance, and adjustments between streamflow-gaging stations are the result of differences in physical structure of the channel and consequent channel hydraulic geometry. For example, Alexander and others (2009) reported that the channel of the Niobrara River at the Hay Springs, Cody, and Sparks streamflow-gaging stations adjusted to increases in discharge mainly through changes in velocity and depth. These adjustment mechanisms are evident in this hydraulic microhabitat analysis because shallower and slower hydraulic conditions are mainly exchanged for deeper and faster conditions with increasing discharge at these sites. 

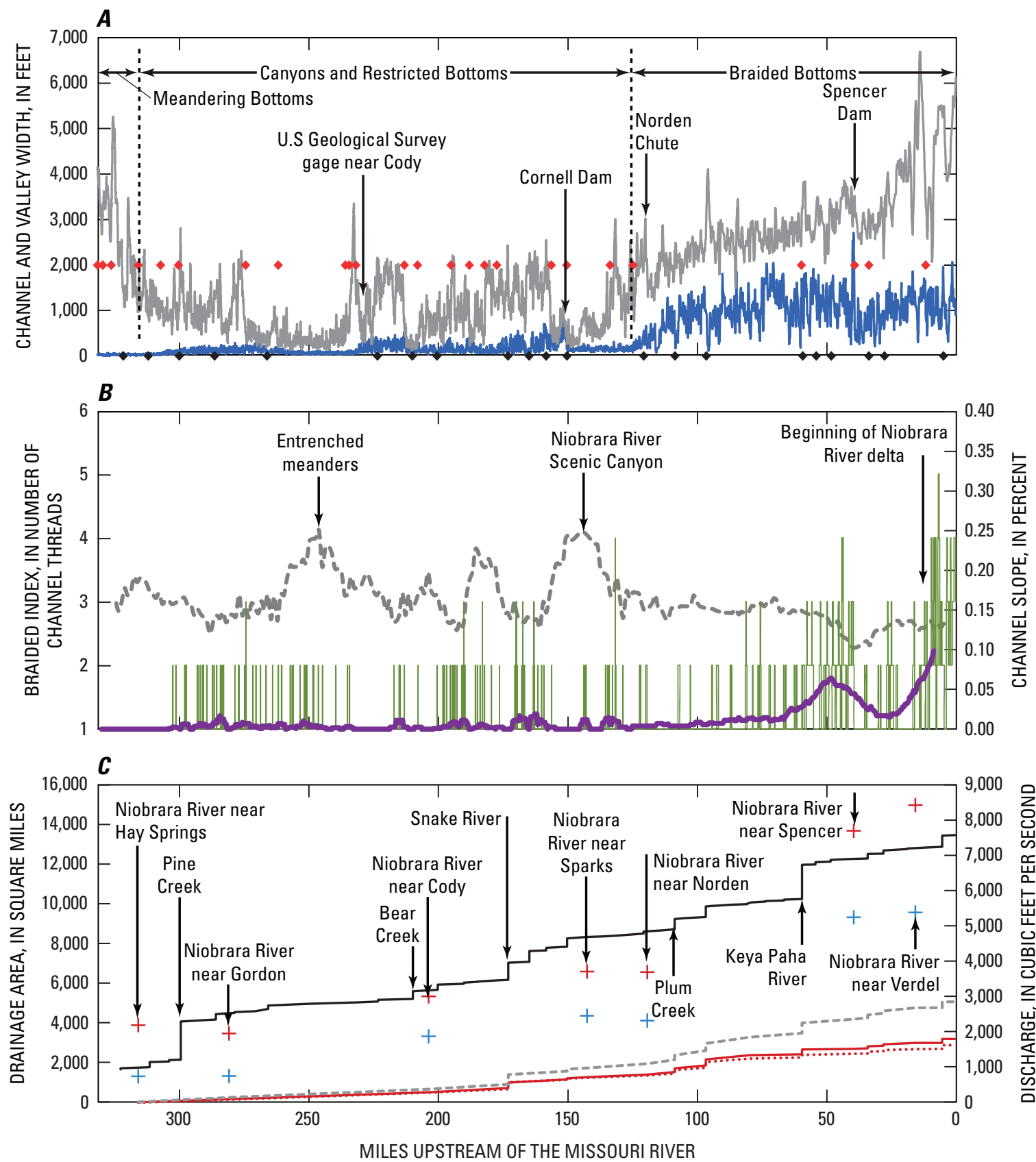

EXPLANATION

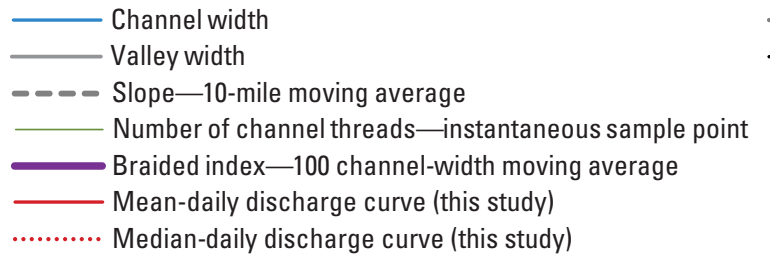

$\longleftrightarrow$ Cumulative drainage area (this study)
$\leftrightarrow \quad$ Tributary confluence
$\quad$ Upstream boundary of hydrogeomorphic segment
$+\quad$ 2-year peak recurrence flood (Soenksen and others, 1999)
$+\quad$ 5-year peak recurrence flood (Soenksen and others, 1999)

Figure 12. Longitudinal distribution of hydrogeomorphic characteristics of the Niobrara River from Dunlap Diversion Dam to the Missouri River, including $(A)$ channel and valley width, location of major tributaries, and location of hydrogeomorphic segments and fluvial geomorphic provinces; $(B)$ channel slope and braided index; (C) cumulative drainage area, longitudinal hydrology curves, and flood frequencies; (D) unit stream power; and (E) channel sinuosity. 

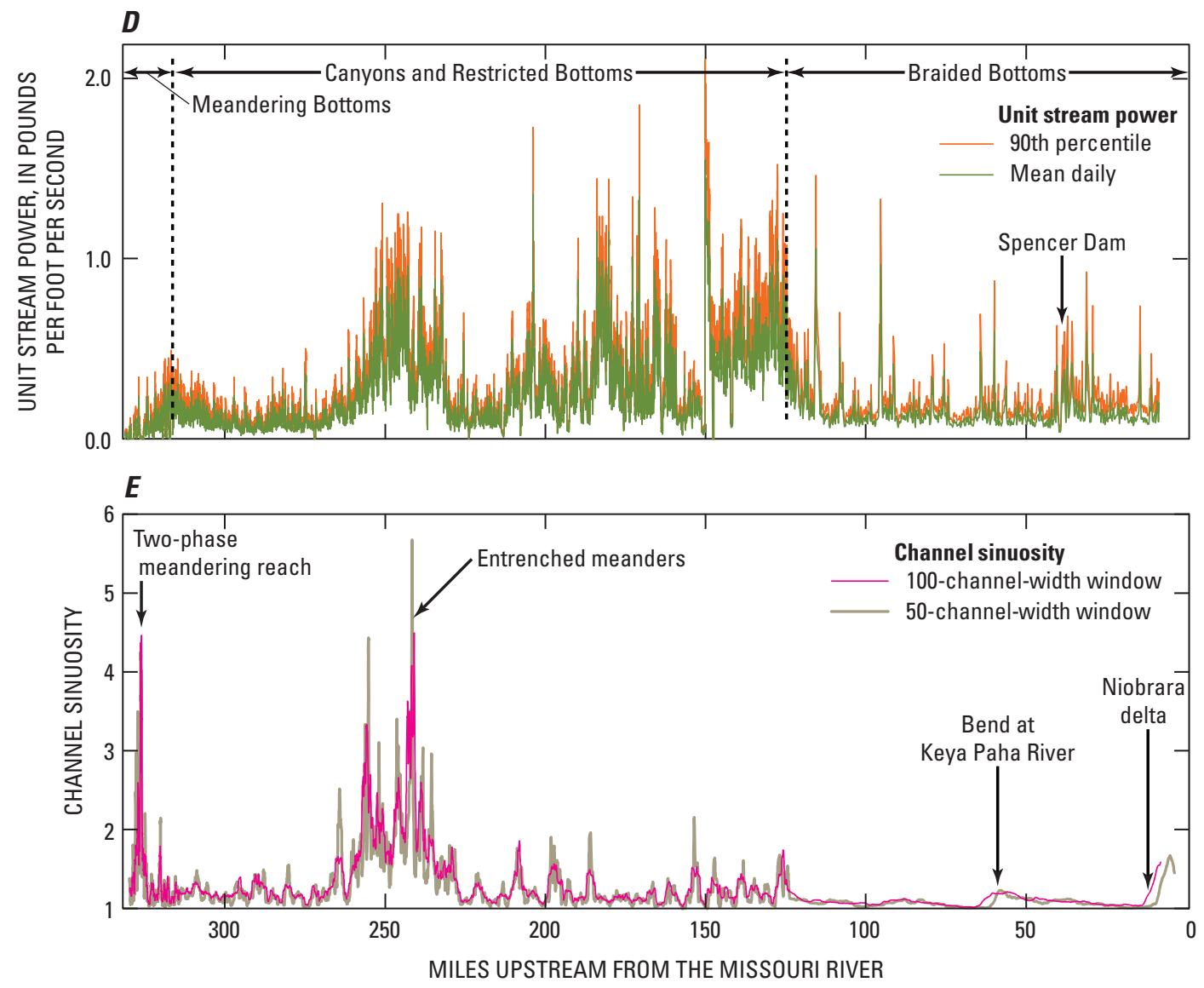

Figure 12. Longitudinal distribution of hydrogeomorphic characteristics of the Niobrara River from Dunlap Diversion Dam to the Missouri River, including $(A)$ channel and valley width, location of major tributaries, and location of hydrogeomorphic segments and fluvial geomorphic provinces; $(B)$ channel slope and braided index; (C) cumulative drainage area, longitudinal hydrology curves, and flood frequencies; $(D)$ unit stream power; and $(E)$ channel sinuosity.-Continued

At the Verdel streamflow-gaging station, it was previously shown that the Niobrara River accommodated increasing discharge with nearly equal changes in width, depth, and velocity (Alexander and others, 2009). The greater role of width-based adjustments at Verdel is reflected in the increase in abundance of intermediate- and shallow-water hydraulic conditions with increasing discharge. This response is the result of the Niobrara River progressively occupying more and more of its channel width, including active-channel sandbars that were not submerged during lower flows, a reflection of its wide and braided nature in the BB fluvial geomorphic province.

The analyses of hydraulic microhabitat conditions presented here emphasize the importance of flow diversity in the creation of a range of hydraulic microhabitat conditions. Intermediate-depth microhabitat conditions, for example, which are preferred by larger fish species (table 6), are absent at the Hay Springs streamflow-gaging station until upperdecile discharge conditions are reached. Similarly, the deeper hydraulic microhabitat conditions are relatively scarce at Cody and Sparks during median-quantile and lower-decile discharge conditions but increase in abundance during the higher discharge conditions. At Verdel, hydraulic-habitat diversity is apparent during all discharge conditions, but the diverse conditions are most balanced, and include increased extent of intermediate and deeper hydraulic niches during higher-magnitude discharges (fig. 13). These deeper, swifter hydraulic niches are likely important seasonal habitat conditions for larger fish, particularly the endangered pallid sturgeon (Scaphirhynchus albus), which has been observed in the recreational reach of the Niobrara River in segment 1 (Wanner and others, 2009). 

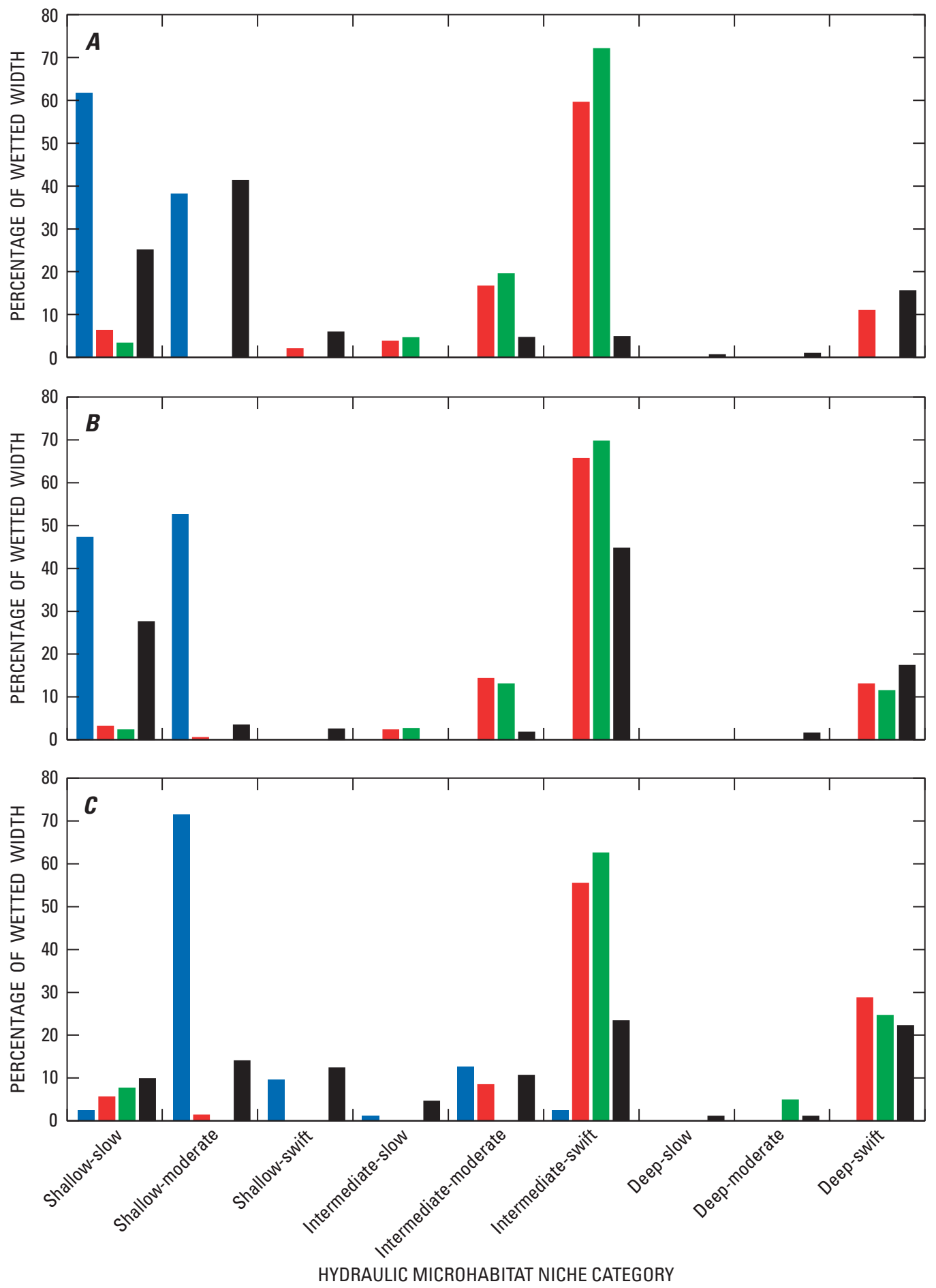

EXPLANATION

$$
\begin{aligned}
& \text { Niobrara River near Hay Springs (06456500) Niobrara River near Sparks (06461500) } \\
& \text { Niobrara River near Cody (06459000) Niobrara River near Verdel (06465500) }
\end{aligned}
$$

Figure 13. Distribution of available hydraulic microhabitats within four reaches at streamflowgaging stations of the Niobrara River, Nebraska, for a range of discharges including $(A)$ lower-decile discharges; $(B)$ median-quantile discharges; and $(C)$ upper-decile discharges. 
Table 14. Hydraulic-microhabitat information over a range of flow conditions for reaches at selected Niobrara River gaging stations in differing fluvial geomorphic provinces.

[All references to stream discharge frequency are from the periods of record at the gage indicated as reported by Alexander and others (2009); meas., measurment; no., number; $\mathrm{ft}^{3} \mathrm{~s}$, cubic feet per second; values shaded with gray indicate a difference of at least a factor of two in the values used to calculate the average; NA, not available]

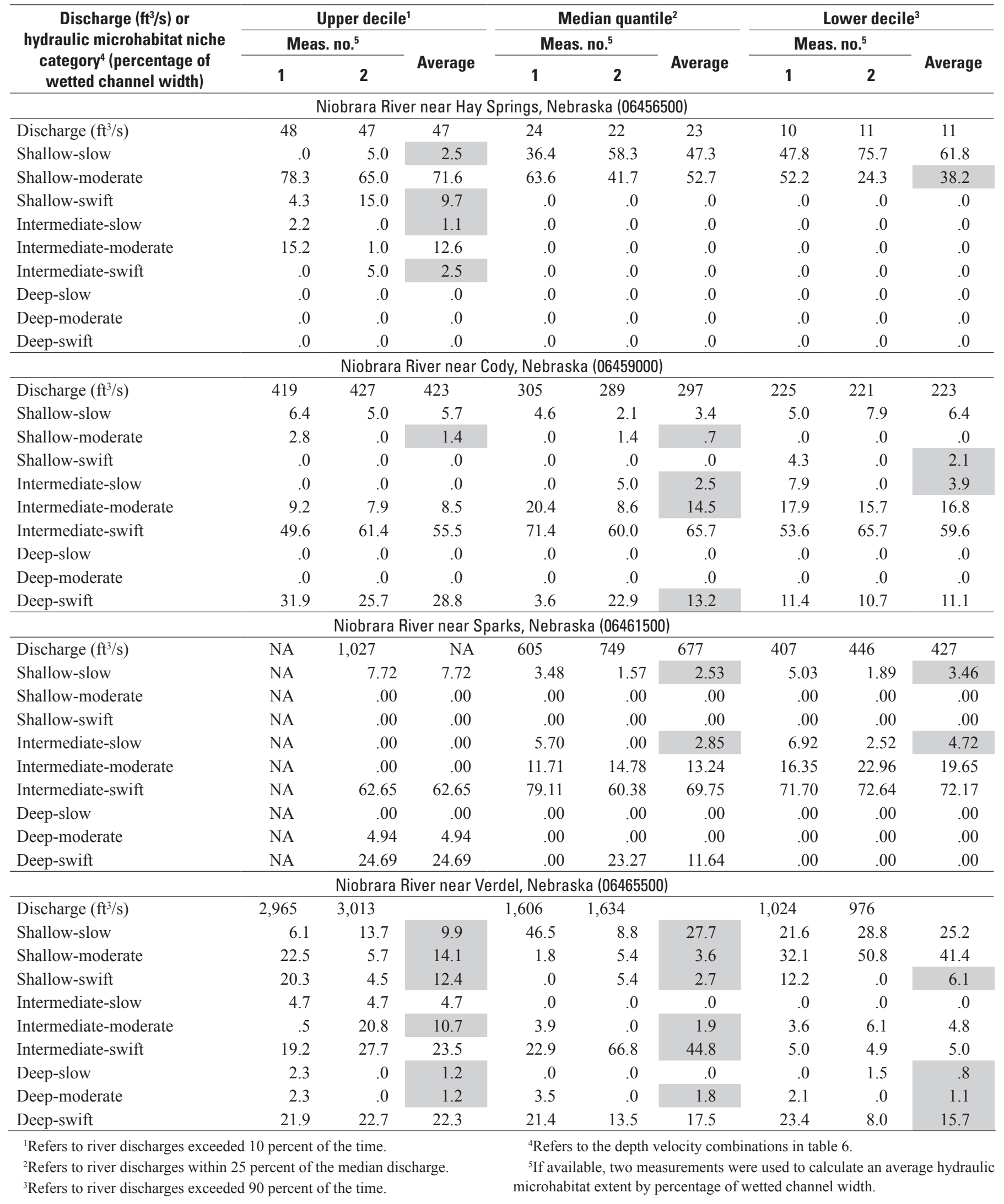




\section{Study Reach Results}

\section{Fluvial Landforms}

Several topographic levels of flood plains and terraces exist within the surveyed parts of the four study reaches at Crooked, Sunny Brook, Muleshoe, and Rock Barn. The frequency distributions of the heights of fluvial landforms, measured as height above the stage of median discharge, indicate at least three gaps in the distribution or breaks in slope - two breaks separating lower landforms and one break separating much higher surfaces, for a total of four landform groups (fig. 14). For descriptive purposes these four landform groups were named in order of increasing elevation as the low flood plains, intermediate flood plains, low terraces, and high terraces. The terraces were poorly characterized because the surveys did not extend across the full width of the alluvial valley bottom. In the discussion below, all references to discharge frequency statistics are in reference to the streamflow record of the Niobrara River near Sparks, Nebr. (06461500), streamflow-gaging station.

The two lowest fluvial landforms are likely active in the modern hydroclimatic regime (fig. 15). The low flood plains are narrow strips of land varying between 3 and $7 \mathrm{ft}$ in width and were only identified on surveyed cross sections in the Crooked study reach (table 15). The elevation of the stage where inundation of the low flood plain begins varies between 0.8 and $1.3 \mathrm{ft}$ above the stage of the median discharge, and corresponds to a discharge of approximately 1,530 to $2,150 \mathrm{ft}^{3} / \mathrm{s}$ or slightly less than the 2-year recurrence flood of $2,470 \mathrm{ft}^{3} / \mathrm{s}$ (Soenksen and others, 1999). The low flood plain is inundated in most years by the annual peak flood and may be "genetic," in the sense that it is constructed of sediments transported by the annual spring flood regime (Nanson and Croke, 1992). Although the low flood plain was only evident in the surveyed cross sections of one of the four study reaches, it was observed in several other reaches of segments 6,7 , and 8 . The

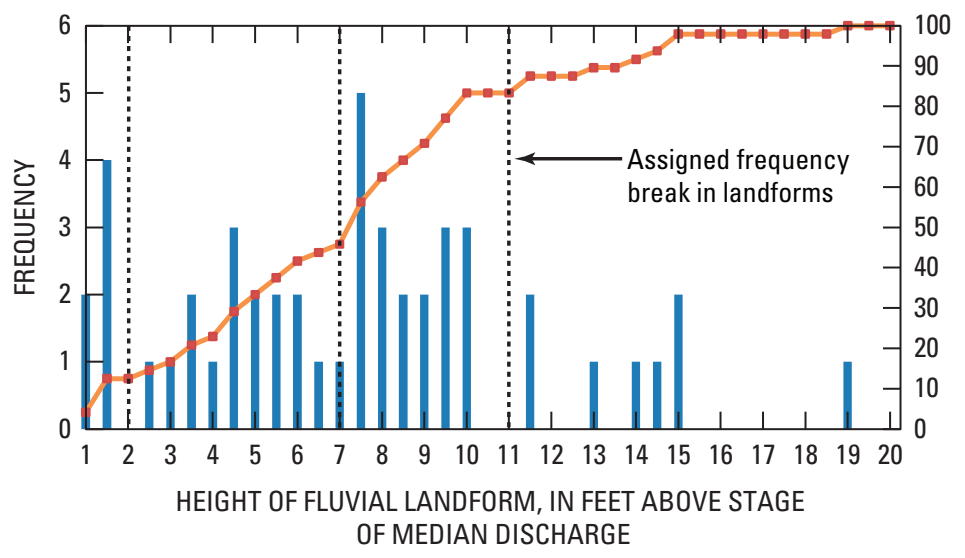

Figure 14. Frequency and cumulative-frequency distributions of the elevation of fluvial landforms in four study reaches of Niobrara National Scenic River, Nebraska.

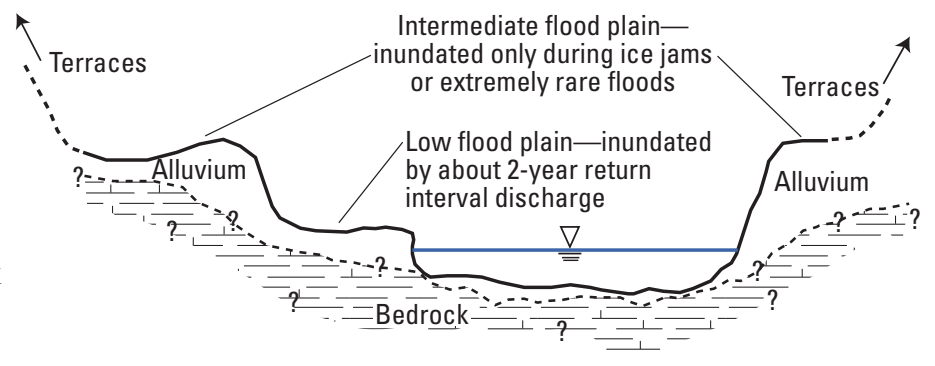

Figure 15. Schematic of active fluvial landforms surveyed in study reaches of Niobrara National Scenic River, Nebraska.

discontinuous nature of the low flood plain is likely the result of occasional destruction or erosion by the higher stages of ice-jam-induced floods.

The intermediate flood plains were identified in all study reaches and vary in width between 4 and $38 \mathrm{ft}$ across and between 2.4 and $6.7 \mathrm{ft}$ above the stage of the median discharge. The intermediate flood plain heights are, on average, approximately $3.4 \mathrm{ft}$ higher than those of the low flood plain. A stage change of $3.4 \mathrm{ft}$ at the nearby Niobrara River near Sparks streamflow-gaging station corresponds to a gain of approximately $10,000 \mathrm{ft}^{3} / \mathrm{s}$ more than the 2-year recurrence flood of 2,470 $\mathrm{ft}^{3} / \mathrm{s}$ (Soenksen and others, 1999), clearly indicating that the intermediate flood plain is not inundated by spring storm runoff processes. The highest peak stages on record at the Sparks stream gage commonly are associated with processes other than normal spring runoff; the most common are damming and breakup of winter ice. The higher end of the stage range of the intermediate flood plain closely corresponds to the range of local ice-jam elevations surveyed in each reach during water year 2008 (table 15) and is in agreement with anecdotal accounts of local residents. The elevations of ice indicators also approach the lower end of the range of elevations of the low terrace surfaces. These data indicate that landforms that appear inactive or only infrequently flooded by storm-related runoff processes may be active on a relatively frequent basis from flooding caused by ice jamming and associated backwater flooding. These data also indicate that channel ice may be a primary driver of channel maintenance, flood plain connectivity, and fluvial depositional processes in the river bottom. The presence of two sets of flood plains - one bounding a narrower channel associated with storm runoff processes and a higher flood plain bounding a wider channel associated with ice jams - has been reported in other rivers where winter ice jams recur at least once every 5 years (Boucher and others, 2009). 
Table 15. Fluvial landforms at cross sections within four study reaches of the Niobrara National Scenic River, Nebraska.

[Cross sections are numbered in ascending order from upstream to downstream; $\mathrm{ft}$, feet; $\mathrm{ft} / \mathrm{s}$, cubic feet per second; brink is defined as minimum elevation at which inundation of the landform begins; Low flood plain is defined as surfaces with elevations between 0.5 to $2.0 \mathrm{ft}$.; Intermediate flood plain is defined as surfaces with elevations between 2.0 and $7.0 \mathrm{ft}$.; Low terraces are defined as surfaces with elevations between 7.0 and $11.0 \mathrm{ft}$.; High terraces are defined as surfaces with elevations greater than $11.0 \mathrm{ft}$.; all elevations are referenced to the estimated stage of median annual discharge; max., maximum; min., minimum]

\begin{tabular}{|c|c|c|c|c|c|c|c|c|c|}
\hline $\begin{array}{l}\text { Cross } \\
\text { section }\end{array}$ & $\begin{array}{c}\text { Elevation of } \\
\text { low flood } \\
\text { plain' } \\
\text { (ft) }\end{array}$ & $\begin{array}{l}\text { Width of low } \\
\text { flood plain } \\
\text { (ft) }\end{array}$ & $\begin{array}{c}\text { Estimated } \\
\text { discharge at } \\
\text { brink }^{3} \\
\left(\mathrm{ft}^{3} / \mathrm{s}\right)\end{array}$ & $\begin{array}{l}\text { Exceed- } \\
\text { ance }{ }^{4}, \\
\text { percent }\end{array}$ & $\begin{array}{l}\text { Elevation of } \\
\text { intermediate } \\
\text { flood plain }{ }^{1} \\
\text { (ft) }\end{array}$ & $\begin{array}{c}\text { Width of } \\
\text { intermediate } \\
\text { flood plain } \\
\text { (ft) }\end{array}$ & $\begin{array}{c}\text { Elevation } \\
\text { of low } \\
\text { terraces } \\
\text { (ft) }\end{array}$ & $\begin{array}{c}\text { Elevation } \\
\text { of high } \\
\text { terraces } \\
\text { (ft) }\end{array}$ & $\begin{array}{c}\text { Elevation } \\
\text { of ic } \mathrm{e}^{5} \\
\text { (ft) }\end{array}$ \\
\hline \multicolumn{10}{|c|}{ Niobrara River upstream of Crooked Creek near Sparks, Nebraska (425429100235301) } \\
\hline 1 & -- & -- & -- & -- & 2.4 & 3.9 & 9.7 & -- & -- \\
\hline 2 & 1.1 & 3.0 & 1,930 & $<0.1$ & -- & -- & -- & -- & -- \\
\hline 3 & .8 & 6.8 & 1,530 & $<.6$ & -- & -- & 8.9 & -- & -- \\
\hline 4 & 1.3 & 6.4 & 2,150 & $<.01$ & 5.1 & 4.9 & 7.3 & -- & -- \\
\hline \multicolumn{10}{|c|}{ Niobrara River at Sunny Brook Campground near Norden, Nebraska (425013100105801) } \\
\hline 1 & -- & -- & -- & -- & 4.8 & 38 & $7.6-9.7$ & -- & $5.9-6.8$ \\
\hline 2 & -- & -- & -- & -- & $4.2-5.9$ & 37 & $8.9-9.6$ & -- & $5.7-6.6$ \\
\hline 3 & -- & -- & -- & -- & 6.7 & 22 & $8.3-9.3$ & 11.1 & $5.6-6.4$ \\
\hline 4 & -- & -- & -- & -- & $2.6-5.6$ & 7 & 7.9-9.1 & -- & $5.3-6.2$ \\
\hline \multicolumn{10}{|c|}{ Niobrara River at Muleshoe Creek near Norden, Nebraska (424925100083201) } \\
\hline 1 & -- & -- & -- & -- & 4.7 & 4.8 & 7.0 & 11.4 & 4.6 \\
\hline 2 & -- & -- & -- & -- & 4.0 & 17 & 7.0 & 18.6 & 4.5 \\
\hline 3 & -- & -- & -- & -- & -- & -- & -- & $12.6-14.4$ & 4.3 \\
\hline 4 & -- & -- & -- & -- & -- & -- & -- & $13.9-14.6$ & 4.2 \\
\hline \multicolumn{10}{|c|}{ Niobrara River at Rock Barn Campground near Norden, Nebraska (424809100065001) } \\
\hline 1 & -- & -- & -- & -- & $5.1-6.5$ & 29 & 8.4 & 14.9 & -- \\
\hline 2 & -- & -- & -- & -- & 3.1 & 6.3 & 7.2 & -- & -- \\
\hline 3 & -- & -- & -- & -- & $3.1-4.4$ & 12 & 7.1 & -- & -- \\
\hline 4 & -- & -- & -- & -- & 4.1 & 35 & 7.5 & -- & -- \\
\hline Max. (ft) & 1.3 & 6.8 & -- & -- & 6.7 & 38 & 9.7 & 18.6 & 6.8 \\
\hline Min. (ft) & .8 & 3.0 & -- & -- & 2.4 & 3.9 & 7.0 & 11.1 & 4.2 \\
\hline Mean (ft) & 1.1 & 5.4 & -- & -- & 4.5 & 18 & 8.3 & 13.9 & 5.5 \\
\hline
\end{tabular}

${ }^{1}$ If two or more surfaces within range are present, values are shown as a range if elevation differences are greater than 0.1 feet and as a single, average value if differences are less than 0.1 feet.

${ }^{2}$ Average width of alluvial surfaces within landform group.

${ }^{3}$ Stage estimated using an approximate rating curve generated from stage-only gage.

${ }^{4}$ Percent of time discharge is equaled or exceeded at Niobrara River near Sparks, Nebraska gage (06461500).

${ }^{5}$ Ice elevations are shown as ranges when more than one ice-stage elevation marker was used. 


\section{Bed Sediment}

Sediment samples obtained in the study reaches indicate that the primary bed material in the active channel ranged in size from coarse silt ( 0.031 to $0.0625 \mathrm{~mm}$ ) to coarse sand $(0.5$ to $1.0 \mathrm{~mm}$ ), and the majority of grain sizes ranged between about 0.2 and $0.5 \mathrm{~mm}$ (fine sand to medium sand) (table 16), similar to those reported by Colby and others (1953). Median grain size diameters of samples ranged from 0.10 to $0.69 \mathrm{~mm}$. Grain-size distributions from samples also indicate that the bed of the Niobrara River coarsens and has increasing grainsize variability in the downstream direction (fig. 16). There could be several reasons for these phenomena. First, the most upstream study reach is approximately 5 mi downstream from Cornell Dam, and the dam may act as a seasonal barrier to coarser grain sizes. Because the sediment samples were obtained in the fall and late fall, several months after peak flows, the coarser grain sizes may have been preferentially trapped behind Cornell Dam. In this case, the bed sediment coarsening and increasing variance would be from the inputs of coarser sediments at tributary junctions, bank erosion, and landslides or other direct hillslope sediment delivery to the channel from the bedrock bluffs.

Second, these phenomena could also be created from differences in the locations and accessibility of bed deposits for sampling. For example, samples obtained at the Crooked study reach were collected only from vegetated dunes along the left (north) side of the channel because the rest of the bed was bedrock. The uniformity of grain sizes in this case is likely the result of sampling of similar bedforms of similar size, all of which were located in approximately the same hydraulic environment, which should, with all other physical constraints held constant, result in a similar grain-size distribution from each sample. Conversely, the samples at the other study reaches were collected on both banks as well as the center of the channel where grain sizes would be expected to be coarser. The larger sample size of the Rock Barn study reach might also be expected to capture more of the sediment grain-size variance. However, it is unlikely that this would explain the downstream patterns considering Sunny Brook and Muleshoe had similar sample sizes and sampling strategies, and the pattern of increased coarsening and grain-size variance is still visible in the data. Furthermore, the median grain sizes of the samples reported here are within the ranges of those reported in previous studies (Colby and others, 1953; Colby and Hembree, 1955; Buchanan, 1981).

\section{Hydraulic Geometry and Hydraulics}

Values of at-a-station hydraulic geometry exponents indicate that the Niobrara River in the study reaches adjusts its geometry to changing discharges primarily through increases in flow depth and velocity. The Crooked study reach had too few measurements, over a relatively narrow range of discharges, to develop statistically meaningful hydraulic-geometry relations. Graphical summaries of study reach at-a-station hydraulic-geometry relations are shown in figure 17. Values for the exponents, coefficients, and goodness-of-fit measures associated with the at-a-station hydraulicgeometry relations are shown in table 17 . Width $(b)$ exponents at five of the six cross sections ranged from a negative value to 0.06 , and four of the statistical models describing width adjustments indicate a lack of significance at the 90-percent confidence level, indicating that the Niobrara River at most locations in the study reaches does not typically accommodate flow increases through changes in channel width.

Exponents at cross section 4 of the Muleshoe study reach (table 17) ranged from 0.29 to 0.37 , indicating that, at least locally, changes in width were also an important channel adjustment mechanism. The higher magnitude width exponent reflects the effect of a mid-channel bedrock bar that was eventually inundated as discharge, and consequently stage, increased. This more complex hydraulic-geometry response is similar to those described further downstream in the BB province (table 1), and is likely representative of reaches, or short sections of reaches, in the CRB province where the channel has localized morphologic complexity associated with midchannel deposition, or variations in bedrock topography. The negative-width exponent was calculated for cross section 1 of the Muleshoe study reach, where variance in width was less than 4 feet over the entire range of flows (table 18). At this particular cross section, the banks were vertical or undercut, and both wading and boat measurements were made. Thus, the variance is likely due to slight differences in technician judgment of the margin of effective flow or, in the case of the highest discharge measurement, a slight shift (upstream or downstream) in the cross section measurement location. Depth $(f)$ and velocity $(m)$ exponents range in value from 0.17 to 0.60 and 0.29 to 0.84 , respectively. All fitted depth- and velocity-adjustment statistical models were significant at the 90-percent confidence level. Exponent sums and coefficient products indicate that the statistical models generally comply with continuity, with 0.11 being the largest deviation from unity.

The estimates of hydraulic geometry coefficients for some of the cross sections in the four study reaches differ in proportion and magnitude from those previously reported for the Niobrara River near Sparks, Nebr., streamflow-gaging station (Alexander and others, 2009). These differences in proportion and magnitude likely are the result of the much wider range and greater number of discharge values used in those previous models. Nonetheless, the models presented here indicate that, over the range of flows measured, the Niobrara River in the sinuous canyon and width-restricted valley settings accommodates increases in flow primarily through increases in channel depth and velocity, with deviations from this model caused by localized channel morphologic complexity. Previously reported hydraulic geometry relations for the Niobrara River indicate that this model of channel-adjustment changes as the Niobrara flows out of the CRB province and into the wider, more complex, braided reaches of the BB fluvial geomorphic province. 
Table 16. Grain-size distributions of selected bed-sediment samples from four study reaches in the Niobrara National Scenic River, Nebraska.

$\left[\mathrm{D}_{\mathrm{n}}\right.$, diameter of the nth percentile of the grain-size cumulative frequency distribution in millimeters; mm, millimeters; $\phi$, phi scale units defined as the negative base-2 logarithm of grain diameter in millimeters; MS, moderately sorted; MWS, moderately well sorted; PS, poorly sorted; WS, well sorted]

\begin{tabular}{|c|c|c|c|c|c|c|c|c|}
\hline $\begin{array}{l}\text { Sample } \\
\text { number }\end{array}$ & $\begin{array}{c}D_{5} \\
(m m)\end{array}$ & $\begin{array}{c}D_{16} \\
(\mathrm{~mm})\end{array}$ & $\begin{array}{c}D_{50} \\
(\mathrm{~mm})\end{array}$ & $\begin{array}{c}D_{84} \\
(\mathbf{m m})\end{array}$ & $\begin{array}{c}D_{95} \\
(\mathbf{m m})\end{array}$ & $\begin{array}{l}\text { Graphic mean } \\
(\mathrm{mm})\end{array}$ & $\begin{array}{c}\text { Inclusive } \\
\text { graphic } \\
\text { standard } \\
\text { deviation }(\phi)\end{array}$ & $\begin{array}{c}\text { Sorting } \\
\text { description } \\
\text { (Folk, 1974) }\end{array}$ \\
\hline \multicolumn{9}{|c|}{ Niobrara River upstream of Crooked Creek near Sparks, Nebraska (425429100235301) } \\
\hline 1 & 0.06 & 0.08 & 0.15 & 0.21 & 0.24 & 0.13 & 0.67 & MWS \\
\hline 2 & .06 & .07 & .12 & .20 & .23 & .12 & .71 & MWS \\
\hline 3 & .06 & .07 & .13 & .21 & .25 & .13 & .71 & MWS \\
\hline 4 & .06 & .07 & .10 & .18 & .22 & .10 & .66 & MWS \\
\hline 5 & .06 & .08 & .14 & .21 & .24 & .13 & .66 & MWS \\
\hline 6 & .06 & .09 & .17 & .24 & .39 & .15 & .74 & MS \\
\hline \multicolumn{9}{|c|}{ Niobrara River at Sunny Brook Campground near Norden, Nebraska (425013100105801) } \\
\hline 1 & 0.07 & 0.12 & 0.18 & 0.26 & 0.43 & 0.17 & 0.69 & MWS \\
\hline 2 & .12 & .14 & .22 & .38 & .46 & .23 & .64 & MWS \\
\hline 3 & .14 & .17 & .29 & .42 & .48 & .27 & .61 & MWS \\
\hline 4 & .13 & .15 & .23 & .39 & .46 & .23 & .63 & MWS \\
\hline 5 & .08 & .14 & .23 & .40 & .48 & .23 & .77 & MS \\
\hline 6 & .07 & .13 & .19 & .33 & .45 & .20 & .73 & MWS \\
\hline 7 & .06 & .10 & .20 & .40 & .56 & .20 & .99 & MS \\
\hline \multicolumn{9}{|c|}{ Niobrara River at Muleshoe Creek near Norden, Nebraska (424925100083201) } \\
\hline 1 & 0.25 & 0.29 & 0.43 & 0.86 & 1.65 & 0.47 & 0.81 & MS \\
\hline 2 & .17 & .26 & .36 & .50 & .88 & .36 & .58 & MWS \\
\hline 3 & .14 & .20 & .32 & .44 & .49 & .31 & .55 & MWS \\
\hline 4 & .07 & .13 & .19 & .34 & .46 & .20 & .79 & MS \\
\hline 5 & .08 & .14 & .27 & .41 & .47 & .25 & .78 & MS \\
\hline \multicolumn{9}{|c|}{ Niobrara River at Rock Barn Campground near Norden, Nebraska (424809100065001) } \\
\hline 1 & 0.03 & 0.04 & 0.10 & 0.31 & 0.52 & 0.11 & 1.33 & PS \\
\hline 2 & .10 & .26 & .40 & .89 & 2.95 & .45 & 1.19 & PS \\
\hline 3 & .16 & .25 & .35 & .48 & .79 & .35 & .59 & MWS \\
\hline 4 & .14 & .18 & .31 & .43 & .48 & .29 & .57 & MWS \\
\hline 5 & .14 & .19 & .32 & .46 & .68 & .30 & .66 & MWS \\
\hline 6 & .15 & .25 & .34 & .45 & .50 & .33 & .48 & WS \\
\hline 7 & .15 & .25 & .35 & .49 & .99 & .25 & .94 & MS \\
\hline 8 & .11 & .14 & .19 & .29 & .42 & .14 & 1.15 & PS \\
\hline 9 & .35 & .52 & .69 & .90 & .99 & .52 & 1.14 & PS \\
\hline 10 & .07 & .10 & .19 & .40 & .98 & .12 & 1.42 & PS \\
\hline 11 & .06 & .09 & .17 & .33 & 1.12 & .11 & 1.59 & PS \\
\hline 12 & .16 & .25 & .35 & .47 & .78 & .25 & 1.70 & PS \\
\hline
\end{tabular}



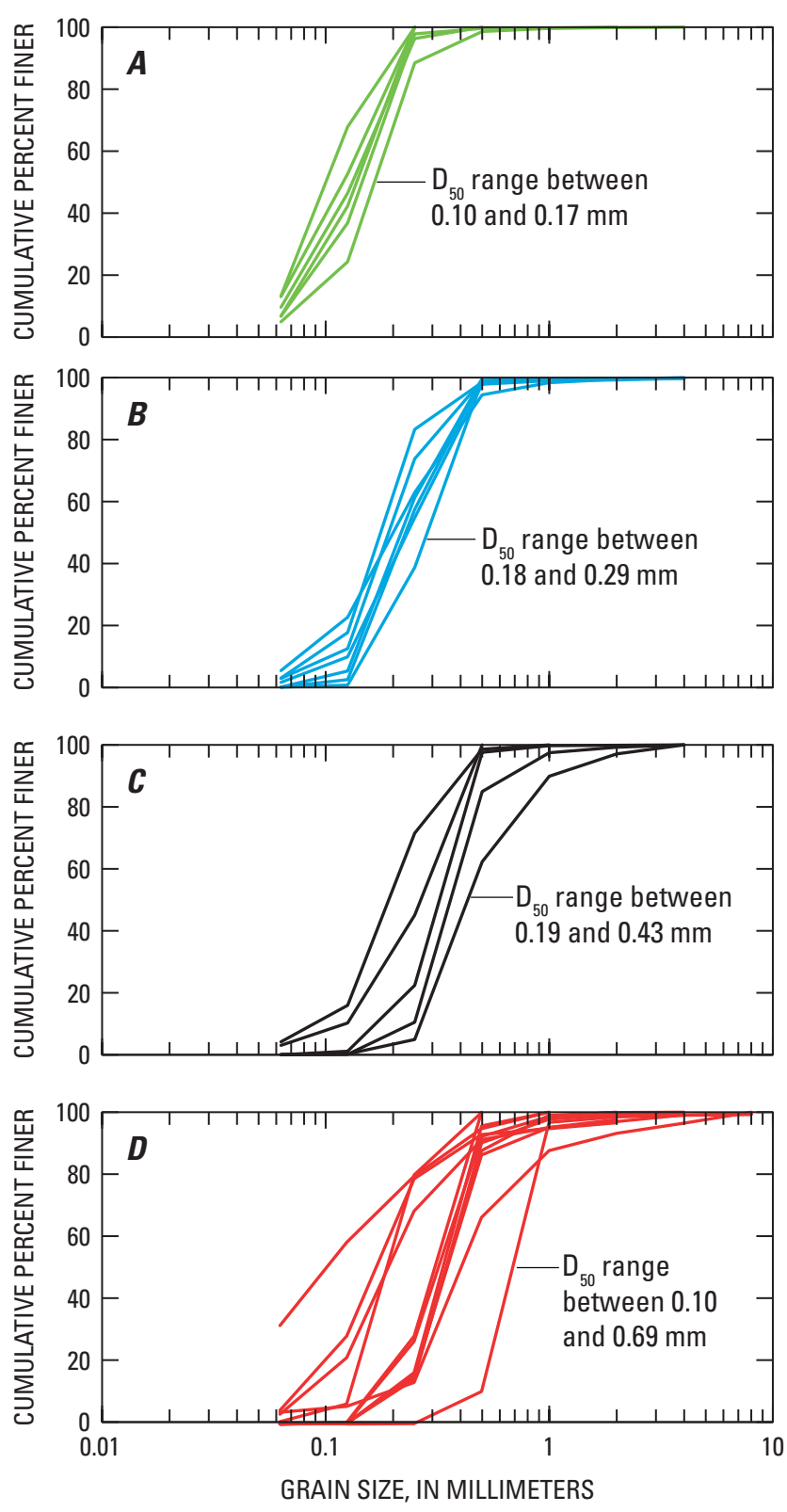

\section{EXPLANATION}

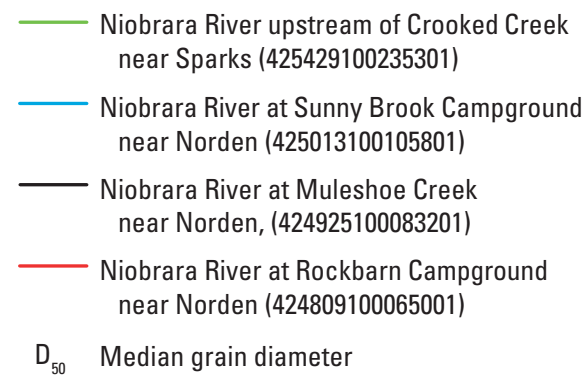

Figure 16. Bed-sediment grain-size cumulative frequency distributions for four study reaches within Niobrara National Scenic River, Nebraska.
Hydraulic behavior over the range of flows measured was not consistent among all reaches, but two general modes can be inferred from the calculated parameters at Sunny Brook, Muleshoe, and Rock Barn (fig. 18). A comparable analysis of hydraulic behavior could not be conducted at the Crooked study reach because too few measurements were made. At the Sunny Brook and Muleshoe study reaches, average boundaryshear stress remained approximately constant for discharges below $900 \mathrm{ft}^{3} / \mathrm{s}$. Above $900 \mathrm{ft}^{3} / \mathrm{s}$, average boundary shear stress increased by approximately 20 to 30 percent (table 18). At the Rock Barn study reach, shear stress showed little to no change in the rate of increase with increasing discharge (fig. 18).

Hydraulic resistance, as measured by the Manning's $n$ (Manning's roughness coefficient), ranged between 0.016 and 0.049 , with the highest resistance occurring at cross section 1 of the Muleshoe study reach. Hydraulic resistance was observed to decrease with increasing discharge below $900 \mathrm{ft}^{3} / \mathrm{s}$ at the Sunny Brook, Muleshoe, and Rock Barn study reaches. Above $900 \mathrm{ft}^{3} / \mathrm{s}$, resistance increased or stabilized at the Sunny Brook and Muleshoe reaches but continued to decrease at the Rock Barn reach.

Unit stream power magnitudes and rates of change varied from reach to reach (fig. 18). Unit stream power had the largest magnitudes and rates of change at Muleshoe, varying between 0.53 and 1.28 pounds per foot-second ( $1 \mathrm{~b} / \mathrm{ft}-\mathrm{s})$, over the range of discharges measured (table 18). The magnitudes and rates of change in unit stream power were nearly identical at Sunny Brook and Rock Barn, with values ranging from 0.22 to $0.57 \mathrm{lb} / \mathrm{ft}-\mathrm{s}$ over the range of discharges measured (table 18). Although not measured over the same range of discharges, the magnitude and rate of change of unit stream power at the Crooked Creek reach appear to be intermediate between those of Muleshoe and the lower values of Sunny Brook and Rock Barn. Unit stream power values calculated from the hydraulic measurements within the study reaches were comparable to the median values of $90^{\text {th }}$ percentile unit stream power estimated for segments 6 and 7 using the GIS data (table 13). Corresponding values of unit stream power for segment 5 , which contains the Rock Barn study reach, are lower than those calculated from hydraulic data measured at Rock Barn, although this is likely because the location of Rock Barn is near the upstream end of segment 7 , which is discussed in more detail below.

The two-mode behavior of shear stress and resistance at the Sunny Brook and Muleshoe reaches (fig. 18) indicates that the bed configuration may have changed - in particular, a transition from dunes (lower regime) to plane bed or antidunes (upper regime) may have occurred at a discharge above $900 \mathrm{ft}^{3} / \mathrm{s}$. When plotted over the bedform classification results of Simons and Richardson (1966), which are based on experimental flume studies, the values of unit stream power for the range of median grain-size diameters sampled (about $0.2 \mathrm{~mm}$ to $0.4 \mathrm{~mm}$ ) indicate that bedforms transition from dunes to plane bed and antidune phases between approximately 0.2 and $0.7 \mathrm{lb} / \mathrm{ft}-\mathrm{s}$ (fig. 19). When examined over the entire range of sample median diameters, the Muleshoe and Sunny Brook 

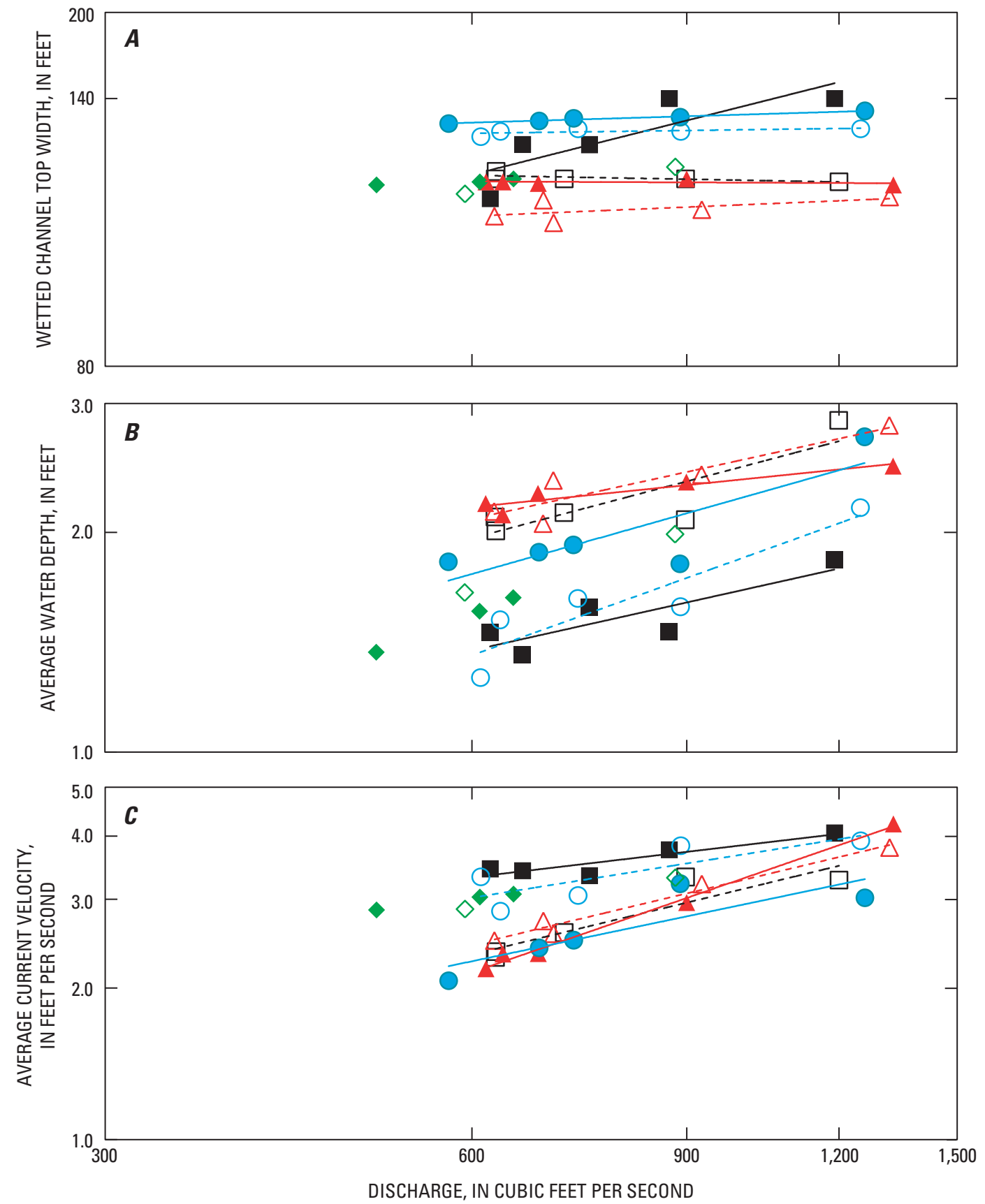

EXPLANATION

Regression fitting lines

Sunny Brook upstream (425013100105801)

Sunny Brook downstream (425013100105801)

-...-.- Muleshoe upstream (424925100083201)

Muleshoe downstream (424925100083201)

. . . . . . Rock Barn upstream (424809100065001)

Rock Barn downstream (424809100065001)
Measurement data points

$\diamond \quad$ Crooked Creek upstream (425429100235301)

- Crooked Creek section 3 (425429100235301)

Sunny Brook upstream (425013100105801)

- Sunny Brook downstream (425013100105801)

$\square \quad$ Muleshoe upstream (424925100083201)

- Muleshoe downstream (424925100083201)

$\triangle$ Rock Barn upstream (424809100065001)

A Rock Barn downstream (424809100065001)

Figure 17. At-a-station hydraulic geometry relations for four study reaches in Niobrara National Scenic River, Nebraska, water years 2008-09, including relations between $(A)$ discharge and wetted channel top width; $(B)$ discharge and average water depth; and $(C)$ discharge and average current velocity. 
Table 17. At-a-station hydraulic geometry relations for four study reaches within Niobrara National Scenic River, Nebraska.

[All stations are located in Nebraska; $\mathrm{ft}^{3} / \mathrm{s}$, cubic feet per second; $a$, width coefficient; $b$, width exponent; $c$, depth coefficient; $f$, depth exponent; $k$, velocity coefficient; $m$, velocity exponent; Q, water discharge, in cubic feet per second; $w$, channel top width, in feet; $d$, average channel depth, in feet; $v$, mean current velocity in feet per second; <, less than; >, greater than; --, no data; COD, coefficient of determination for least-squares estimate of regression equation]

\begin{tabular}{|c|c|c|c|c|c|c|c|c|}
\hline \multirow{8}{*}{$\begin{array}{l}\text { Exponent } \\
\text { coefficient or } \\
\text { statistic }\end{array}$} & \multicolumn{8}{|c|}{ Station name } \\
\hline & \multicolumn{2}{|c|}{$\begin{array}{c}\text { Niobrara River upstream of } \\
\text { Crooked Creek near Sparks } \\
(425429100235301)^{1}\end{array}$} & \multicolumn{2}{|c|}{$\begin{array}{l}\text { Niobrara River at Sunny Brook } \\
\text { Campground near Norden } \\
\text { (425013100105801) }\end{array}$} & \multicolumn{2}{|c|}{$\begin{array}{c}\text { Niobrara River at Mule- } \\
\text { shoe Creek near Norden } \\
\text { (424925100083201) }\end{array}$} & \multicolumn{2}{|c|}{$\begin{array}{c}\text { Niobrara River at Rock Barn } \\
\text { Campground near Norden } \\
\text { (424809100065001) }\end{array}$} \\
\hline & \multicolumn{8}{|c|}{ Location within study reach ${ }^{2}$} \\
\hline & $\begin{array}{c}\text { Cross } \\
\text { section } 1\end{array}$ & $\begin{array}{c}\text { Cross } \\
\text { section } 3\end{array}$ & $\begin{array}{c}\text { Cross } \\
\text { section } 1\end{array}$ & $\begin{array}{c}\text { Cross } \\
\text { section } 4\end{array}$ & $\begin{array}{c}\text { Cross } \\
\text { section } 1\end{array}$ & $\begin{array}{c}\text { Cross } \\
\text { section } 4\end{array}$ & $\begin{array}{c}\text { Cross } \\
\text { section } 1\end{array}$ & $\begin{array}{c}\text { Cross } \\
\text { section } 4\end{array}$ \\
\hline & 2 & 3 & 5 & 5 & 5 & 5 & 5 & 5 \\
\hline & \multicolumn{8}{|c|}{ Maximum discharge of included measurements, in $\mathrm{ft}^{3} / \mathrm{s}$} \\
\hline & 881 & 649 & 1,250 & 1,260 & 1,320 & 1,330 & 1,200 & 1,190 \\
\hline & \multicolumn{8}{|c|}{ Minimum discharge of included measurements, in $\mathrm{ft}^{3} / \mathrm{s}$} \\
\hline$b$ & -- & -- & .02 & .04 & -.02 & .35 & .06 & -.01 \\
\hline COD & -- & -- & .39 & .98 & .47 & .70 & .39 & .11 \\
\hline p-value ${ }^{3}$ & -- & -- & .26 & $<.01$ & .20 & $<.1$ & .26 & 0.59 \\
\hline \multicolumn{9}{|c|}{ Depth coefficients and exponents (equation $2 ; d=c 0^{f}$ ) } \\
\hline$c$ & -- & -- & 0.03 & 0.09 & 0.12 & 0.13 & 0.20 & 0.72 \\
\hline$f$ & -- & -- & .60 & .47 & .44 & .37 & .37 & .17 \\
\hline COD & -- & -- & .84 & .70 & .74 & .72 & .85 & .87 \\
\hline $\mathrm{p}$-value ${ }^{3}$ & -- & -- & $<.1$ & $<.1$ & $<.1$ & $<.1$ & $<.1$ & $<.1$ \\
\hline \multicolumn{9}{|c|}{ Velocity coefficients and exponents (equation $3 ; v=k Q^{m}$ ) } \\
\hline & -- & -- & 0.98 & 0.89 & 0.99 & 0.98 & 1.00 & 0.98 \\
\hline \multicolumn{9}{|c|}{ Sum of exponents } \\
\hline & -- & -- & 1.00 & 1.02 & 1.00 & 1.00 & 1.00 & 1.00 \\
\hline
\end{tabular}

${ }^{1}$ Too few data points were available to develop hydraulic geometry relations for station 425429100235301.

${ }^{2}$ Cross sections are numbered in ascending order from upstream to downstream and spaced approximately a single channel width apart.

${ }^{3}$ Probability (p-value) that regression slope is zero (no correlation between discharge and geometric variable); values less than 0.10 indicate model significance at the 90-percent confidence level. 
reaches are on the margin or entirely within the transition to upper flow-regime (plane bed/antidune) bed phases.

The Rock Barn study reach did not exhibit the same two-mode hydraulic behavior observed at the Sunny Brook and Muleshoe reaches. Although there may be several reasons for this, it was hypothesized that the difference in hydraulic behavior was related to two primary differences in the Rock Barn reach. First, the Rock Barn reach has a combination of lower unit stream power and coarser, less well-sorted bed sediment. When plotted over the Simons and Richardson (1966) bedform classification, the coarser grain sizes sampled within the reach indicated the bed would have been in lower regime, although the median and smallest grain sizes sampled would have been transitional or fully upper regime (fig. 19). These results indicate that for the ranges of grain sizes sampled, a plane-bed or antidunes bed state may have been present but not stable at the highest discharge measured. Second, and potentially more important, the channel more than doubles in total wetted width just downstream from the Rock Barn study reach. The width expansion downstream may have prevented the same type of hydraulic threshold behavior from occurring in the Rock Barn study reach. The expansion and contraction in channel width over short distances are common in the BB fluvial geomorphic province, which begins a short distance upstream from the Rock Barn reach. Because of their wider channel widths, the expansion zones would be expected to have lower unit stream power per unit discharge, and therefore, would require greater discharge to reach the same bedload transport rates as those in narrow reaches.

Although channel velocities, grain sizes, and transitional bed-state boundaries seem to reasonably converge when viewed in relation to the bedform classification data of Simons and Richardson (1966), the Froude numbers calculated for the measured flows are low, indicating that the flows may have been dominantly lower regime (table 18). For example, Leeder (1999) reports that, in general, antidunes occur as stable forms at Froude values of 0.84 or higher. However, experimental data from Athaullah (1968) indicate that transitional to upperregime bedforms may occur at Froude numbers as low as 0.3 to 0.6 for the grain sizes and channel geometries measured for this study (fig. 20). The median grain size used for relative roughness (ratio of hydraulic radius to median bed grain size) in figure 20 is the median $\mathrm{D}_{50}$ of all samples collected in the three study reaches with substantial fine sediment coverage of the bed-Sunny Brook, Muleshoe, and Rock Barn. Although the experimental data of Simons and Richardson (1966) and Athaullah (1968) are not in perfect agreement, both indicate that the bed state in the study reaches was, at a minimum, transitional during the higher measured discharges, and both indicate that the Sunny Brook and Muleshoe reaches were more likely to have been in an upper flow regime bed state than was Rock Barn.

The coincident increase in boundary shear stress above $900 \mathrm{ft}^{3} / \mathrm{s}$ observed at the Sunny Brook and Muleshoe study reaches represents a potential hydraulic threshold above which bedload transport rates were likely to increase markedly. If the rate of change in bed shear with discharge is generally monotonic beyond the discharges measured, a second hydraulic shift would be expected once the stage of the river exceeds the height of the low flood plain. Once the stage of the flood plain is reached, the width of the river would be expected to increase rapidly, forcing a second shift in unit stream power values, a change in the rate of change of depth with increasing discharge, and subsequently, a shift in the rate of change of boundary shear stress with discharge (Leopold and others, 1964; Richards, 1977; Bridge, 2003).

\section{Bed Adjustment}

The seasonal bed elevation of the Niobrara River in the study reaches did not exhibit consistent behavior over the range of flows or over the season (fig. 21). The three reaches that were observed to have substantial coverage of the bed by fine sediment-Sunny Brook, Muleshoe, and Rock Barn - exhibited greater bed elevation variability than did the bedrock-dominated Crooked study reach, as would be expected. The upper cross sections at Sunny Brook and Muleshoe were both deepened (scoured) over the course of the season, indicating that the bed was evacuating a supply of sediment. Conversely, the cross sections at Rock Barn and the lower cross section at Sunny Brook were stable or aggrading sediment over the season. The upper cross section at Rock Barn and the lower cross section at Sunny Brook aggraded with increasing discharge, whereas the upper cross sections at Sunny Brook and Muleshoe scoured. Because the deposits on the bed shift frequently, especially at higher discharges, it is likely that these data are not temporally adequate to fully characterize the behavior of the river bed in the study reaches (Colby, 1964). Nonetheless, no consistent bed-adjustment pattern (scour or fill) was identified among reaches. 


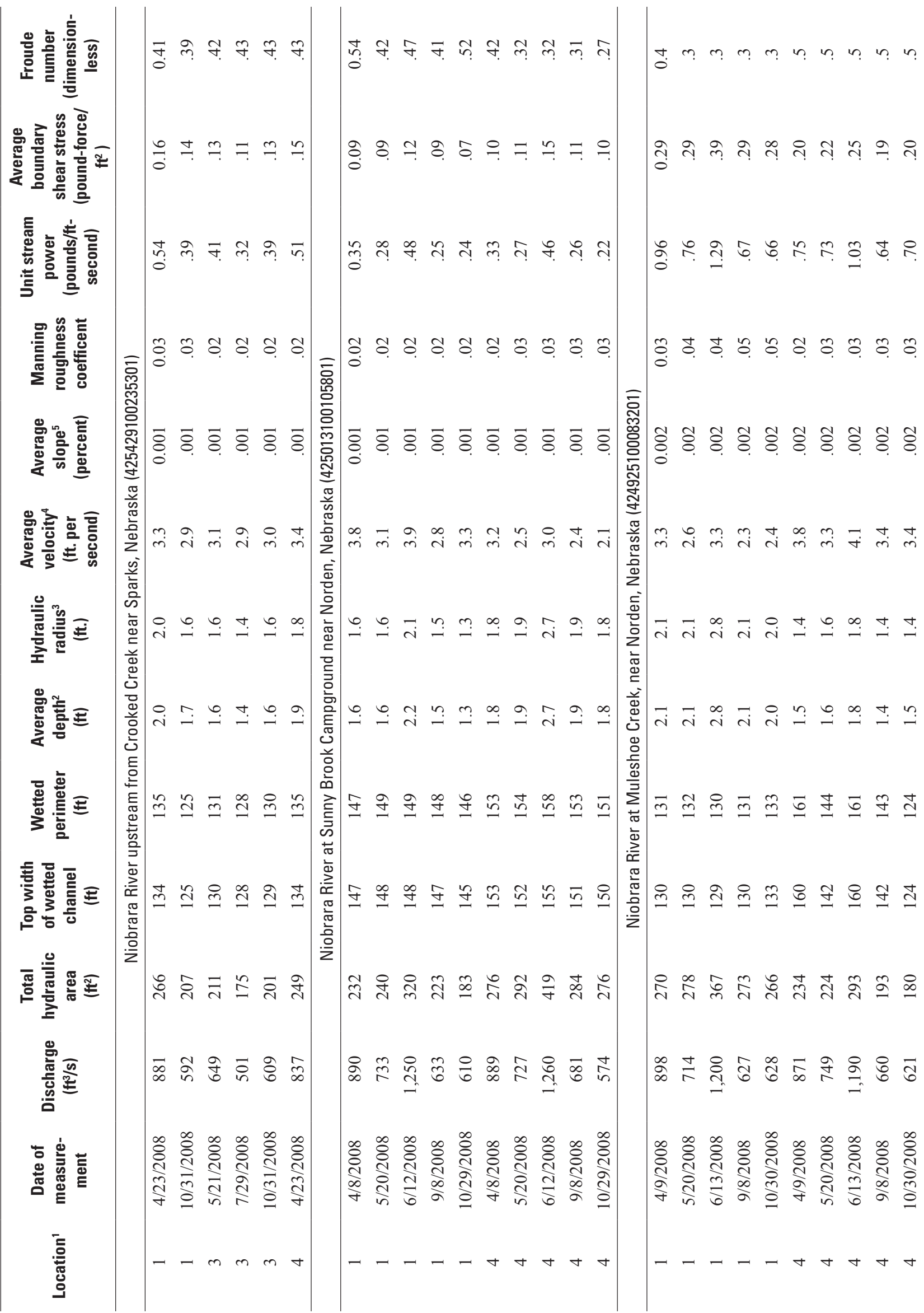




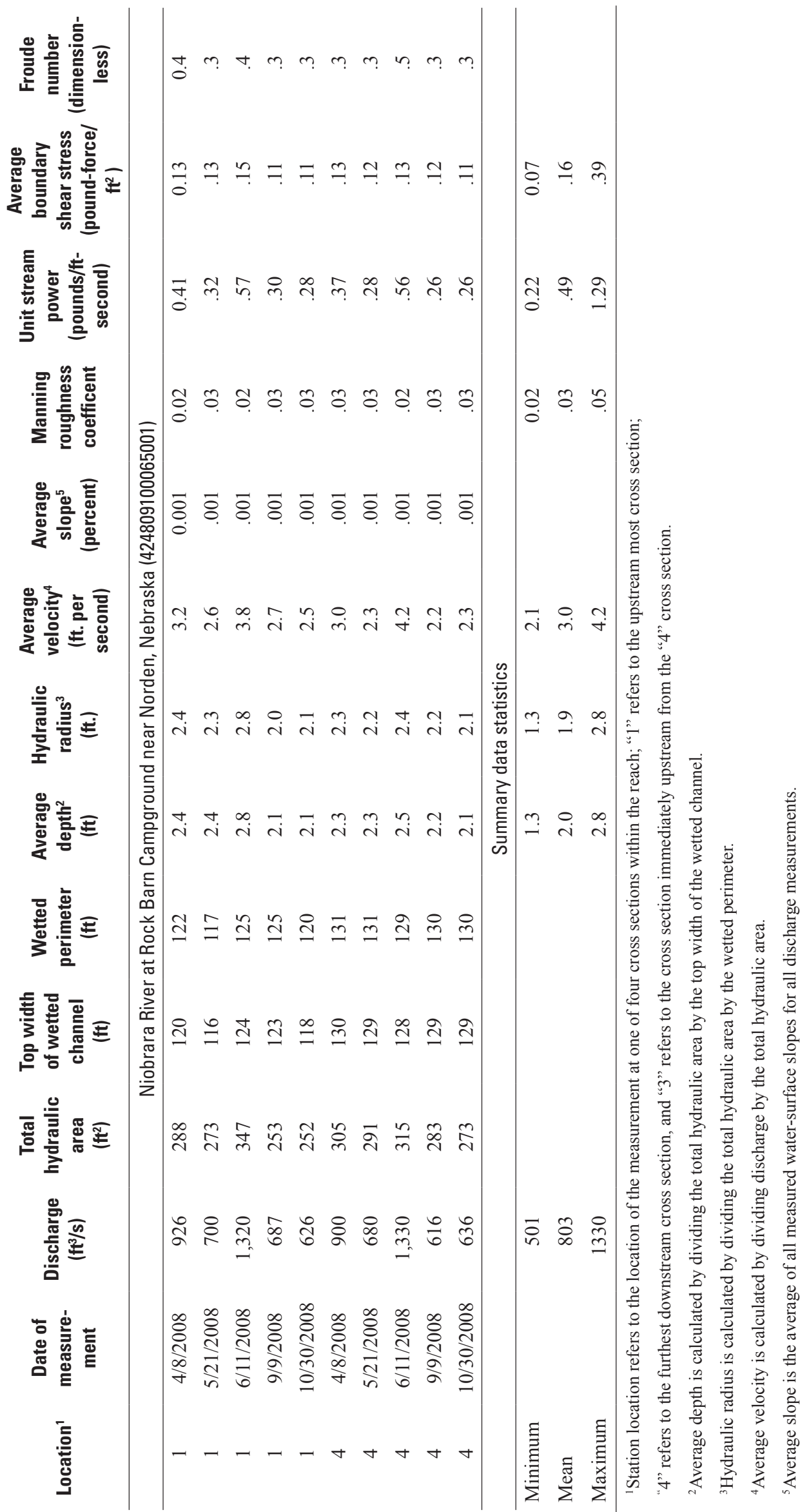



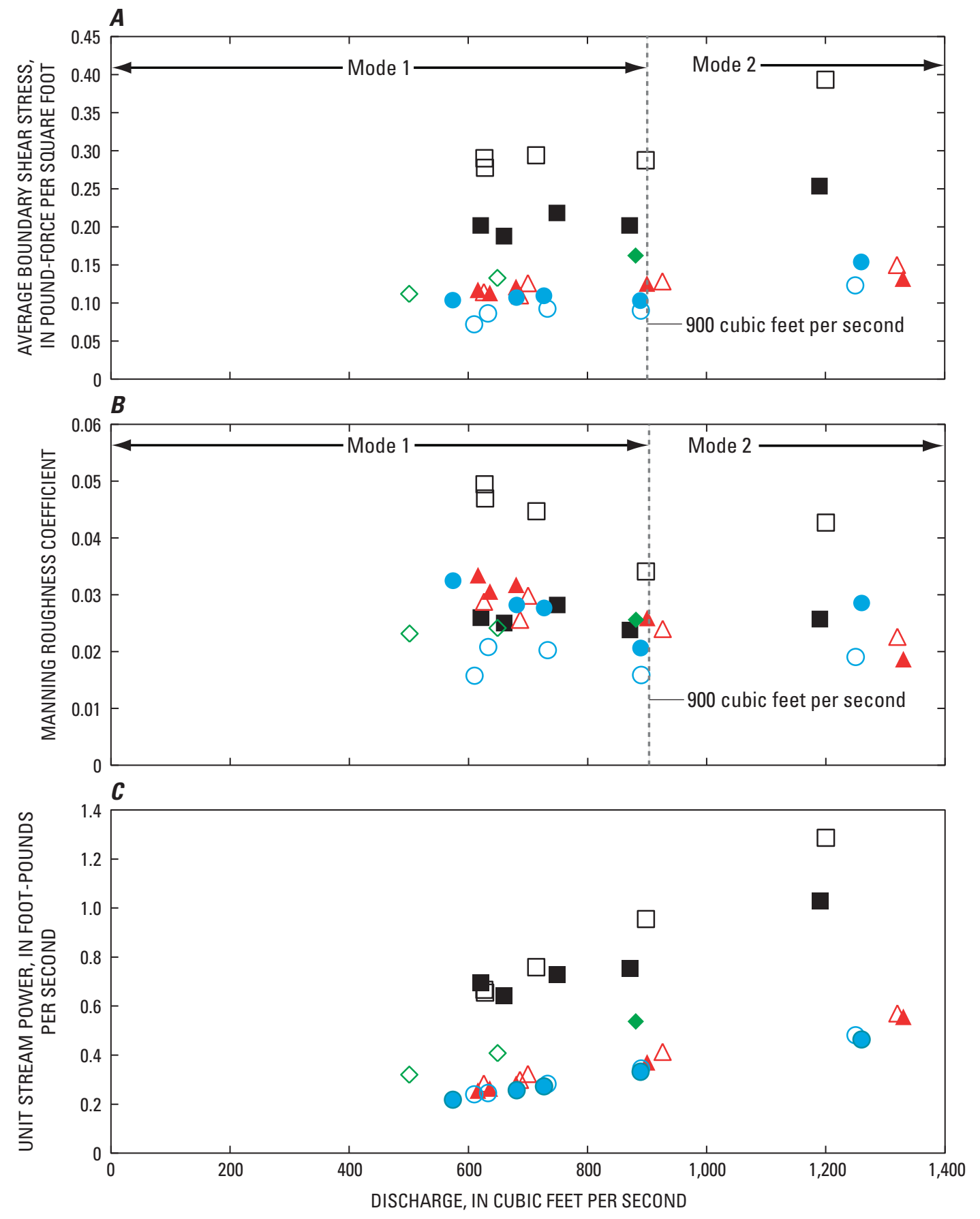

EXPLANATION

$\diamond$ Crooked Creek upstream (425429100235301)

Crooked Creek section 3 (425429100235301)

Sunny Brook upstream (425013100105801)

Sunny Brook downstream (425013100105801) $\square$ Muleshoe upstream (424925100083201)

Muleshoe downstream (424925100083201)

$\triangle$ Rock Barn upstream (424809100065001)

Rock Barn downstream (424809100065001)

Figure 18. Variation in selected hydraulic parameters over a range of discharges in four study reaches of Niobrara National Scenic River, Nebraska, water years 2008-09, including relations between $(A)$ discharge and average boundary shear stress; $(B)$ discharge and the Manning roughness coefficient; and $(C)$ discharge and unit stream power. 

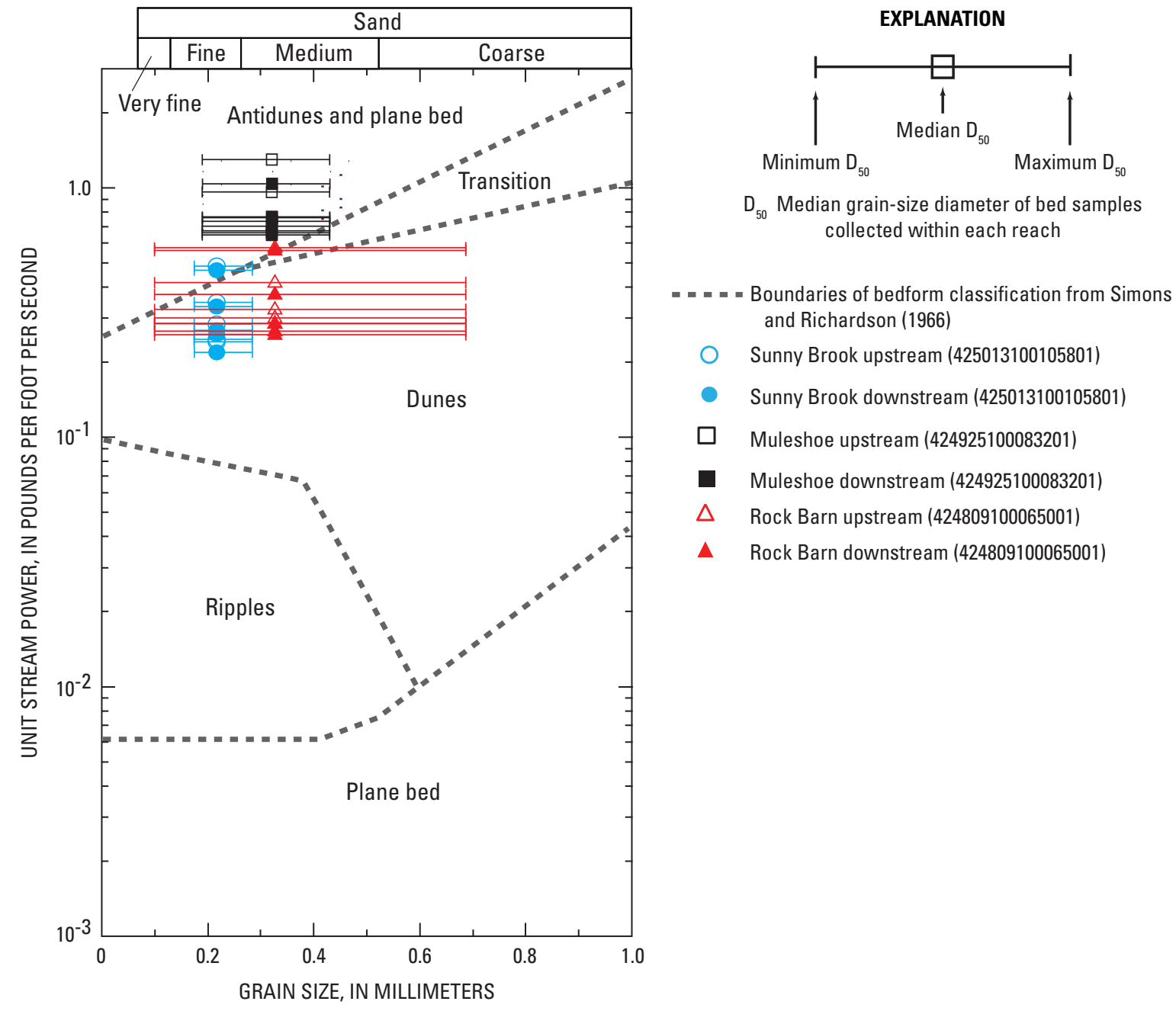

Figure 19. Relation of unit stream power to median grain-size diameters sampled over the range of discharges measured in three study reaches of the Niobrara National Scenic River, Nebraska.

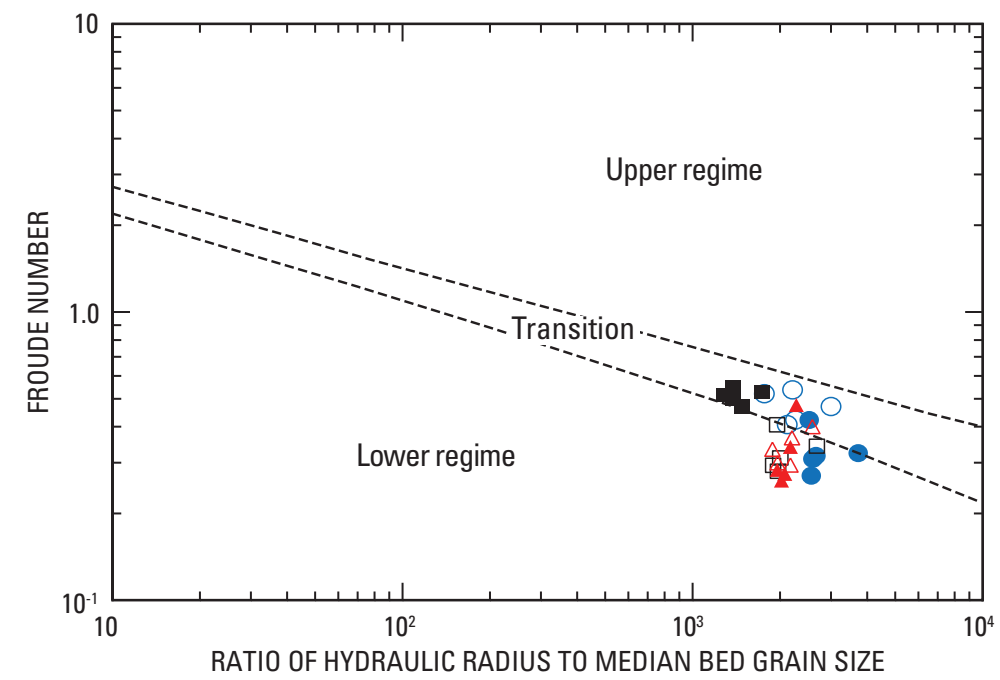

\section{EXPLANATION}

Boundaries of zones based on experimental flume data of Athaullah (1968)

Sunny Brook upstream (425013100105801)

- Sunny Brook downstream (425013100105801)

$\square \quad$ Muleshoe upstream (424925100083201)

- Muleshoe downstream (424925100083201)

$\triangle \quad$ Rock Barn upstream (424809100065001)

A Rock Barn downstream (424809100065001)

Figure 20. Relation of Froude number to dimensionless relative roughness ratio over the range of discharges measured in three study reaches of the Niobrara National Scenic River, Nebraska. 


\section{Hydraulic Microhabitats}

Analysis of hydraulic microhabitats over the range of discharges measured at the study reaches indicates that some percentage of most habitat niche categories was available for at least one discharge condition, but the majority of hydraulic habitat available was within the intermediate-swift and deep-swift habitat niche categories (table 19). Deepswift conditions dominated nearly all study reaches under all measured discharge conditions. This is particularly so during median-quantile and upper-decile discharges, when the intermediate-swift and deep-swift hydraulic microhabitat niches were dominant (fig. 22). Slight differences in habitat distributions were observed between the three study reaches with substantial coverage of the bed by fine sediment (Sunny Brook, Muleshoe, and Rock Barn) and the bedrock-dominated reach (Crooked). At the Crooked reach, the intermediate-swift habitat category dominated the distribution during the lowest measured discharge (still within median-quantile frequency range), and the deep-swift habitat category dominated during the median-quantile discharge. No flows were measured at the Crooked reach that qualified for the upper-decile dischargefrequency category. With the exception of the Sunny Brook reach, the deep-swift habitat niche dominated the distribution for all ranges of discharges in the reaches with substantial amounts of sand on the bed. At Sunny Brook, the intermediate-swift habitat niche dominated during median-quantile discharges, but the deep-swift niche dominated during the lowest measurements and upper-decile categories.

The four study reaches (table 7) are located in three different hydrogeomorphic segments and, consequently, would be expected to exhibit differences in physical characteristics (table 13). The Crooked reach is located in segment 7, Sunny Brook and Muleshoe are located in segment 6, and Rock Barn is located in segment 5. Although these reaches occupy three different hydrogeomorphic segments, the habitat niche types, abundance of particular habitat niches, and response of microhabitat niche distributions to changing discharge conditions

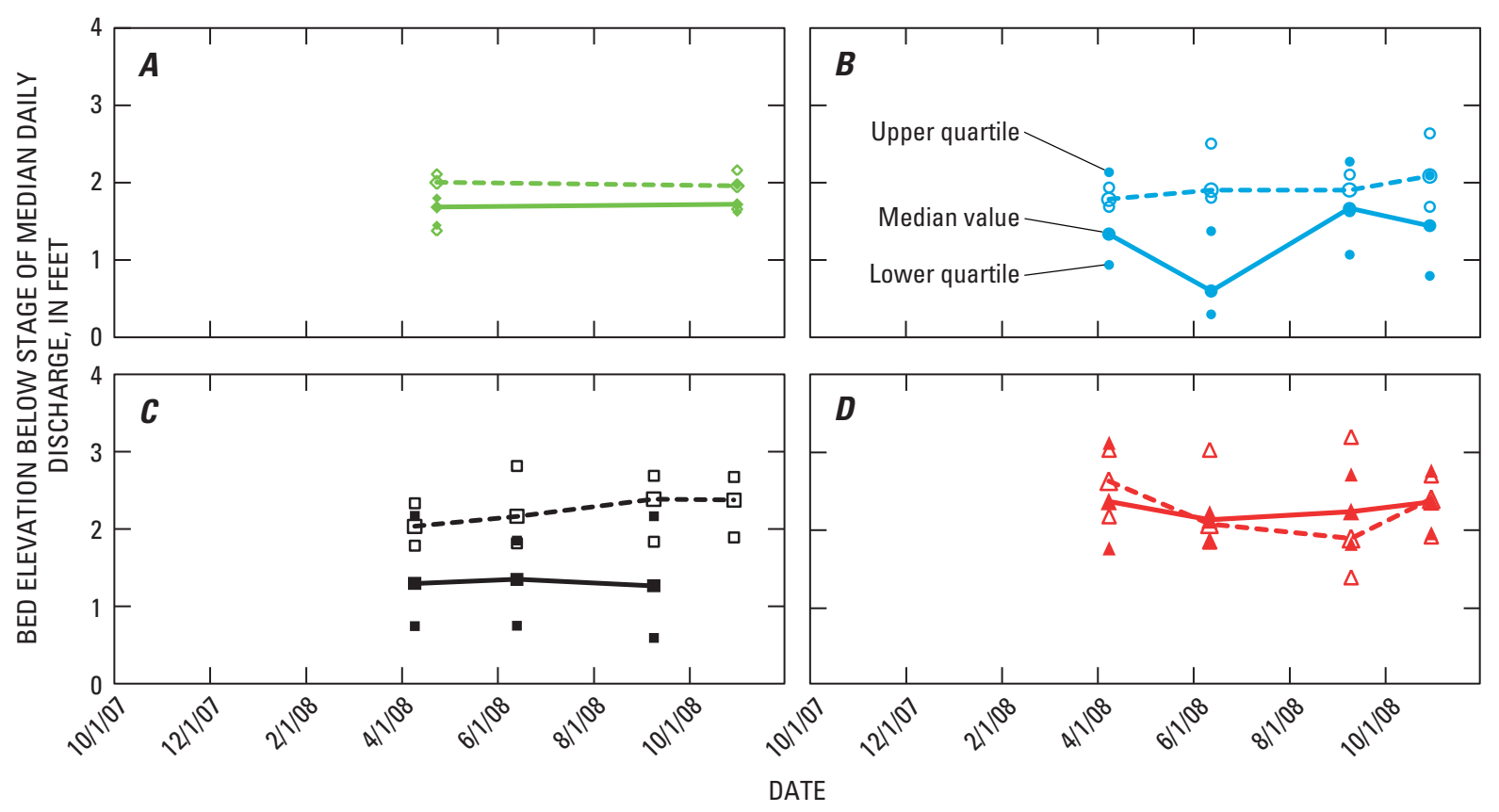

EXPLANATION

Quartiles of the bed-elevations surveyed on indicated date at each cross section
$\Delta \quad$ Connects median values from most downstream cross section in reach
Coned Creek upstream (425429100235301)
$\quad$ Crooked Creek 3 (425429100235301)
$\quad$ Sunny Brook upstream (425013100105801)
$\square \quad$ Sunny Brook downstream (425013100105801)
$\square \quad$ Muleshoe upstream (424925100083201)
$\Delta \quad$ Rock Barn usptream (424809100065001)
$\Delta \quad$ Rock Barn downstream (424809100065001)

Figure 21. Seasonal changes in bed elevation of river channel at cross sections within four study reaches of Niobrara National Scenic River, Nebraska. 
(fig. 22) generally were similar among all reaches. The types of niches and response of hydraulic habitat distributions to changing discharge conditions in these four reaches were most similar to those at the Sparks gaging station (described above), where the primary habitat adjustment was an increase in flow depth. This similarity in response was not unexpected because three of the four reaches are in the CRB fluvial geomorphic province and have similar at-a-station hydraulic geometries. The hydraulic geometry analysis above and in the previous study (Alexander and others, 2009) showed that the river in the $\mathrm{CRB}$ province mainly accommodated increasing discharge through increases in depth and velocity. As compared to the Sparks gage, the study reaches all had greater abundance of the deeper habitat categories over the range of discharge frequencies analyzed. At the Rock Barn reach, which is in the BB fluvial geomorphic province, the response of hydraulic microhabitat distribution was virtually identical to those of the other reaches.

Several reasons are hypothesized for similar distributions of hydraulic microhabitat niches at each study reach even though they are located in differing hydrogeomorphic segments and fluvial geomorphic provinces. First, the study reaches were chosen prior to the development of the segment classification system and, therefore, were not chosen on the basis of providing physical representation of particular fluvial classes. Rather, reaches were primarily chosen on the basis of hydraulic uniformity to maximize discharge-measurement accuracy. Second and potentially related to the first, all reaches had similar channel top-widths with cross sections ranging in width from approximately 120 to $160 \mathrm{ft}$ (fig. 17). This, in combination with similar discharges, produced the similarity in channel hydraulic-habitat distributions. Third, the Rock Barn study reach that by nominal expectation should differ from others because it is in a different fluvial geomorphic province, is located only 1.2 miles into the BB province and is similar in width and slope to Sunny Brook reach. Thus, although the reaches immediately upstream and downstream from Rock Barn are more characteristic of the BB province, the study reach itself has physical and hydraulic characteristics similar to those in the CRB province. To fully characterize the hydraulic microhabitat niche types, extents, and response to changing flow conditions in contrasting segments within and between provinces, a more elaborate field study would be necessary that focuses on particular hydrogeomorphic settings representing differing channel morphologic features.

\section{Summary}

The Niobrara River is an ecologically and economically important resource in Nebraska. The Nebraska Department of Natural Resources' recent designation of the hydraulically connected surface- and groundwater resources of the Niobrara River Basin as "fully appropriated" has emphasized the importance of understanding linkages between the physical and ecological dynamics of the Niobrara River so it can be sustainably managed. Numerous scientific studies have investigated the physical and hydraulic attributes of the Niobrara River along isolated reaches; however, none have placed these characteristics within a spectrum of fluvial settings at the basin scale. Such a study may provide the physical context for water-management strategies and serve as a framework for integrated physical and biological investigations. In cooperation with the Nebraska Game and Parks Commission, the U.S. Geological Survey investigated the hydrogeomorphic and hydraulic attributes of the Niobrara River in northern Nebraska. This report presents the results of an analysis of hydrogeomorphic segments and hydraulic microhabitats of the Niobrara River and its valley for the approximately 330-mi reach from Dunlap Diversion Dam to its confluence with the Missouri River. Two spatial scales were used to examine and quantify the hydrogeomorphic segments and hydraulic microhabitats of the Niobrara River: a basin scale and reach scale.

At the basin scale, digital spatial data and hydrologic data were analyzed to (1) test for differences between 36 previously determined longitudinal hydrogeomorphic segments; (2) quantitatively describe the hydrogeomorphic characteristics of the river and its valley; and (3) evaluate differences in hydraulic microhabitat over a range of flow regimes among three fluvial geomorphic provinces.

The statistical analysis of hydrogeomorphic segments resulted in reclassification rates of 3 to 28 percent of the segments for the four descriptive geomorphic elements. The reassignment of classes by discriminant analysis resulted in a reduction from 36 to 25 total hydrogeomorphic segments because several adjoining segments shared the same ultimate class assignments among individual descriptive geomorphic elements. Virtually all of the segment mergers were in the CRB fluvial geomorphic province. Class reassignments and merger of hydrogeomorphic segments did not result in changes to the statistical modal class for any descriptive geomorphic element relative to those reported previously for the study area. The most frequent conditions (modal classes) among hydrogeomorphic segments are a width-restricted valley confinement condition, sinuous planview pattern, irregular channel width, and an alternate bar configuration. The class reassignments and segment mergers did, however, result in changes to the dominant classes per unit length of river, which are now the same as the modal classes.

The Niobrara River in the study area flows through a diversity of fluvial geomorphic settings in its traverse across northern Nebraska. The most distinct differences are among the settings found in three fluvial geomorphic provinces. In the Meandering Bottoms (MB) province, river discharge magnitudes are low, the median channel width varies from 20 to $30 \mathrm{ft}$, but the valley is over 3,000 ft wide in places, and exerts little control on the channel-planview pattern. Within the Canyons and Restricted Bottoms (CRB) province, the river flows over a diversity of geologic formations, and the valley and river narrow and expand in approximate synchronicity, in some cases forming entrenched canyons, with steep channel 
Table 19. Hydraulic microhabitat distribution over a range of streamflow conditions for four study reaches in Niobrara National Scenic River, Nebraska.

[All references to stream discharge frequency are from the period of record of 1964 through 2007 for the Niobrara River near Sparks, Nebraska, streamflowgaging station (06461500); ft³/s, cubic feet per second; meas., measurement; no., number; --, no data]

\begin{tabular}{|c|c|c|c|c|c|c|c|c|c|}
\hline \multirow{3}{*}{$\begin{array}{c}\text { Discharge (ft/3) or hydraulic } \\
\text { microhabitat niche category } \\
\text { (percentage of wetted channel } \\
\text { width) }\end{array}$} & \multicolumn{3}{|c|}{ Upper decile $^{1}$} & \multicolumn{3}{|c|}{ Median quantile $^{2}$} & \multicolumn{3}{|c|}{ Lowest measurement $^{3}$} \\
\hline & \multicolumn{2}{|c|}{ Meas. no. ${ }^{5}$} & \multirow{2}{*}{ Average } & \multicolumn{2}{|c|}{ Meas. no. ${ }^{5}$} & \multirow{2}{*}{ Average } & \multicolumn{2}{|c|}{ Meas. no.5 } & \multirow{2}{*}{ Average } \\
\hline & 1 & 2 & & 1 & 2 & & 1 & 2 & \\
\hline \multicolumn{10}{|c|}{ Niobrara River upstream of Crooked Creek near Sparks, Nebraska (425429100235301) } \\
\hline Discharge $\left(\mathrm{ft}^{3} / \mathrm{s}\right)$ & -- & -- & -- & 837 & 881 & 859 & 501 & -- & -- \\
\hline Shallow-slow & -- & -- & -- & 2.1 & 2.8 & 2.4 & 2.7 & -- & 2.7 \\
\hline Shallow-moderate & -- & -- & -- & .0 & 1.1 & .6 & 7.0 & -- & 7.0 \\
\hline Shallow-swift & -- & -- & -- & .0 & .0 & .0 & 3.9 & -- & 3.9 \\
\hline Intermediate-slow & -- & -- & -- & .0 & .0 & .0 & 3.5 & -- & 3.5 \\
\hline Intermediate-moderate & -- & -- & -- & 6.7 & 4.9 & 5.8 & 3.9 & -- & 3.9 \\
\hline Intermediate-swift & -- & -- & -- & 41.4 & 20.9 & 31.2 & 78.9 & -- & 78.9 \\
\hline Deep-slow & -- & -- & -- & .0 & .0 & .0 & .0 & -- & .0 \\
\hline Deep-moderate & -- & -- & -- & .0 & 1.5 & .7 & .0 & -- & .0 \\
\hline Deep-swift & -- & -- & -- & 49.8 & 68.8 & 59.3 & .0 & -- & .0 \\
\hline \multicolumn{10}{|c|}{ Niobrara River at Sunny Brook Campground near Norden, Nebraska (425013100105801) } \\
\hline Discharge $\left(\mathrm{ft}^{3} / \mathrm{s}\right)$ & 1,264 & 1,253 & 1,258 & 889 & 890 & 890 & 578 & 610 & 594 \\
\hline Shallow-slow & 1.5 & 1.5 & 1.5 & 3.1 & 2.7 & 2.9 & 7.6 & 17.2 & 12.4 \\
\hline Shallow-moderate & .0 & .0 & .0 & .0 & 2.0 & 1.0 & 1.2 & 15.2 & 8.2 \\
\hline Shallow-swift & .0 & .0 & .0 & .0 & 11.9 & 6.0 & .0 & 9.0 & 4.5 \\
\hline Intermediate-slow & 2.7 & .0 & 1.4 & 2.1 & .0 & 1.1 & 8.6 & .0 & 4.3 \\
\hline Intermediate-moderate & .0 & 5.1 & 2.5 & 7.2 & 2.7 & 5.0 & 32.4 & 4.7 & 18.5 \\
\hline Intermediate-swift & .0 & 42.2 & 21.1 & 63.4 & 46.6 & 55.0 & 6.6 & 28.1 & 17.3 \\
\hline Deep-slow & 2.3 & .0 & 1.1 & .0 & .0 & .0 & .0 & .0 & .0 \\
\hline Deep-moderate & 13.2 & 1.7 & 7.5 & 2.0 & .0 & 1.0 & 10.4 & .0 & 5.2 \\
\hline Deep-swift & 80.3 & 49.5 & 64.9 & 22.1 & 34.0 & 28.1 & 33.2 & 25.9 & 29.5 \\
\hline
\end{tabular}

slopes, yet highly sinuous channel patterns. In the Braided Bottoms (BB) fluvial geomorphic province, the river primarily flows over Cretaceous Pierre Shale, the valley and channel are persistently wide, and the channel slope is generally uniform. The existence of vegetated islands and consequent multithread channel environments, indicated by a higher braided index, mostly coincided with reaches having gentler slopes and less unit stream power. Within the MB province, stream power is relatively low, but channel slope is persistently steeper than 0.15 percent, and no islands were identified. Within the CRB province, channel slope is highly variable, braided index rarely exceeds 2 , and islands are concentrated mainly in the reaches having mild slopes and lower unit stream power. In the BB province, braided index was, on average, higher than in the upstream provinces, but islands are mainly concentrated in the delta reach near the mouth at the Missouri River and in the reach immediately upstream from Spencer Dam.
Longitudinal hydrology curves indicate that the flow of the Niobrara River likely is dominated by groundwater as far downstream as Norden. Upstream from Norden, the mean daily, median, and 90th-percentile discharge curves have approximately the same longitudinal slope and have only minor differences in overall magnitude. Between the Snake River confluence and Norden, all three hydrologic curves begin to diverge, indicating the hydrologic regime becomes more variable as the river flows out of the CRB and into the BB province. Unit stream power values in the study area vary between 0 and almost 2 pounds per foot per second. Within the MB province, unit stream power steadily increases as the Niobrara gains discharge from groundwater inflow, and the channel slope steepens. The combination of steep slopes, a constrained channel width, and persistent flow within the CRB province results in unit stream power values that are between three and five times greater than those in less 
Table 19. Hydraulic microhabitat distribution over a range of streamflow conditions for four study reaches in Niobrara National Scenic River, Nebraska.-Continued

[All references to stream discharge frequency are from the period of record of 1964 through 2007 for the Niobrara River near Sparks, Nebraska, streamflowgaging station (06461500); ft³/s, cubic feet per second; meas., measurement; no., number; --, no data]

\begin{tabular}{|c|c|c|c|c|c|c|c|c|c|}
\hline \multirow{3}{*}{$\begin{array}{c}\text { Discharge }\left(\mathrm{ft}^{3} / \mathrm{s}\right) \text { or hydraulic } \\
\text { microhabitat niche category } \\
\text { (percentage of wetted channel } \\
\text { width) }\end{array}$} & \multicolumn{3}{|c|}{ Upper decile ${ }^{1}$ (percent) } & \multicolumn{3}{|c|}{ Median quantile ${ }^{2}$ (percent) } & \multicolumn{3}{|c|}{ Lowest measurement ${ }^{3}$ (percent) } \\
\hline & \multicolumn{2}{|c|}{ Meas. no. ${ }^{5}$} & \multirow{2}{*}{ Average } & \multicolumn{2}{|c|}{ Meas. no. ${ }^{5}$} & \multirow{2}{*}{ Average } & \multicolumn{2}{|c|}{ Meas. no. ${ }^{5}$} & \multirow{2}{*}{ Average } \\
\hline & 1 & 2 & & 1 & 2 & & 1 & 2 & \\
\hline \multicolumn{10}{|c|}{ Niobrara River at Muleshoe Creek near Norden, Nebraska (424925100083201) } \\
\hline Discharge $\left(\mathrm{ft}^{3} / \mathrm{s}\right)$ & 1,191 & 1,202 & 1,196 & 879 & 898 & 888 & 622 & 628 & 625 \\
\hline Shallow-slow & .9 & 1.9 & 1.4 & 10.0 & 2.5 & 6.3 & 27.3 & 7.7 & 17.5 \\
\hline Shallow-swift & .0 & .0 & .0 & 15.0 & .0 & 7.5 & 6.9 & .0 & 3.4 \\
\hline Intermediate-slow & .6 & .0 & .3 & .0 & .0 & .0 & .0 & 2.8 & 1.4 \\
\hline Intermediate-moderate & 2.5 & 3.1 & 2.8 & 1.6 & 13.1 & 7.3 & 5.3 & 23.4 & 14.3 \\
\hline Intermediate-swift & 42.2 & .0 & 21.1 & 25.6 & 17.3 & 21.5 & 19.4 & 5.3 & 12.4 \\
\hline \multicolumn{10}{|c|}{ Niobrara River at Rock Barn Campground near Norden, Nebraska (424809100065001) } \\
\hline Discharge $\left(\mathrm{ft}^{3} / \mathrm{s}\right)$ & 1,335 & 1,319 & 1,327 & 900 & 925 & 913 & 637 & 626 & 631 \\
\hline Shallow-slow & 2.3 & 4.0 & 3.2 & 5.4 & 2.5 & 5.1 & 5.8 & 9.7 & 7.8 \\
\hline Shallow-moderate & .0 & .0 & .0 & .0 & 7.9 & 4.3 & 1.6 & .0 & .8 \\
\hline Shallow-swift & .0 & 3.0 & 1.5 & .0 & .0 & .0 & .0 & .0 & .0 \\
\hline Intermediate-slow & .0 & .0 & .0 & .0 & 2.1 & 2.9 & 5.4 & 2.1 & 3.8 \\
\hline Intermediate-moderate & 3.7 & .0 & 1.9 & 11.2 & 2.7 & 4.4 & 3.9 & 8.5 & 6.2 \\
\hline Intermediate-swift & 9.8 & 12.1 & 10.9 & 16.9 & 11.7 & 11.3 & 16.3 & 5.7 & 11.0 \\
\hline Deep-slow & .0 & .0 & .0 & .0 & 1.7 & .8 & .0 & .0 & .0 \\
\hline
\end{tabular}

${ }^{1}$ Refers to river discharges exceeded 10 percent of the time.

${ }^{2}$ Refers to river discharges within 25 percent of the median discharge.

${ }^{3} \mathrm{Hydraulic}$ microhabitat distribution at the lowest discharge measurements made during the study period.

${ }^{4}$ Refers to the depth velocity combinations in table 6 .

${ }^{5}$ If available, two measurements were used to caclulate an average hydraulic microhabitat extent.

confined segments with comparable or greater discharges. With the exception of hydrogeomorphic segment 3, which is affected by Spencer Dam, unit stream power values in the BB province are generally uniform. This consistency results from downstream increases in discharge that are offset by steady decreases in channel slope and steady increases in channel width downstream from Norden. Channel sinuosity values in the study area varied generally between 1 and 2.5 , but with locally higher values measured in the MB province and at the entrenched bedrock meanders of hydrogeomorphic segment 18 in the CRB province. Within hydrogeomorphic segment 24 of the MB province, the Niobrara River has very little flow, and the channel has a two-phase meander pattern. Within hydrogeomorphic segment 18 , the river has a highly sinuous pattern that is entrenched in bedrock, and the presence of rincons (abandoned bedrock meander bends) and the bedrock bed indicate that the river is cutting down through the bedrock at a relatively rapid rate. Channel sinuosity is lowest in the long, generally straight, braided reaches of the BB province.

The differences in channel morphology and hydraulic geometries between fluvial geomorphic provinces are evident in the types, relative abundance, and response of hydraulic microhabitat niches to changing discharges. The four gaging stations chosen for hydraulic microhabitat analysis 

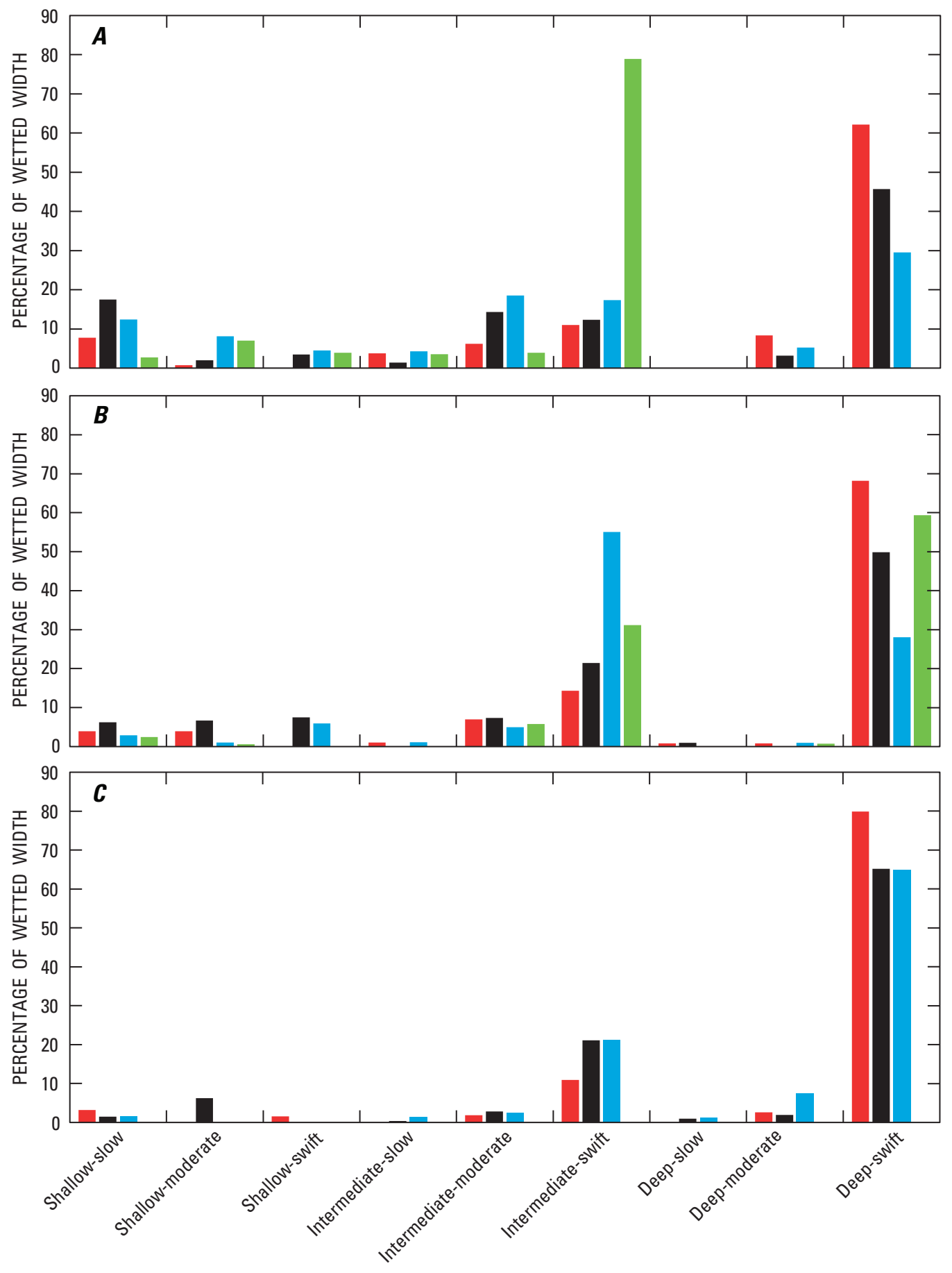

HYDRAULIC MICROHABITAT NICHE CATEGORY

EXPLANATION

Niobrara River upstream of Crooked Creek (425429100235301)

- Niobrara River at Sunny Brook Campground (425013100105801)
- Niobrara River at Muleshoe Creek (424925100083201)

- Niobrara River at Rock Barn Campground (434809100065001)

Figure 22. Distribution of available hydraulic microhabitats within four study reaches of the Niobrara National Scenic River, Nebraska, for a range of discharges, including $(A)$ lowest discharges measured; $(B)$ median-quantile discharge; and $(C)$ upper-decile discharge. 
are distributed among three different fluvial geomorphic provinces: Hay Springs (MB), Cody (CRB), Sparks (CRB), and Verdel (BB). The hydraulic microhabitat availability was calculated as the average for two discharges (when available) within three discharge-duration exceedance categories-lower-decile, median-quantile, and upper-decile. At Hay Springs, the smaller channel and lower discharges resulted in the dominance of shallow and intermediate-depth hydraulic environments with the vast majority of hydraulic microhabitat restricted to shallow categories even during upper-decile discharges. At Cody and Sparks, intermediate-depth hydraulic conditions, particularly intermediate-swift, dominate at both gages over all analyzed ranges of discharge; as discharge increases, intermediate-depth hydraulic conditions are mainly exchanged for deeper hydraulic conditions. Hydraulic microhabitat conditions are most diverse in the wide, braided reach of Verdel, with most hydraulic microhabitat niche categories present over the entire range of discharges analyzed. However, as discharge increased to upper-decile flow conditions, hydraulic microhabitats were more evenly distributed, with no hydraulic habitat niche category covering more than 25 percent of the total channel width. The calculated differences in hydraulic microhabitat distributions, abundance, and adjustments between streamflow-gaging stations are the result of differences in physical structure of the channel and consequent channel hydraulic geometry. Previous reports indicated that the channel of the Niobrara River at the Hay Springs, Cody, and Sparks streamflow-gaging stations adjusted to increases in discharge mainly through changes in velocity and depth. These adjustment mechanisms are evident in this hydraulic microhabitat analysis because shallower and slower hydraulic conditions are mainly exchanged for deeper and faster conditions with increasing discharge at these sites. The greater role of width-based adjustments at Verdel is reflected in the increase in abundance of intermediate- and shallowwater hydraulic conditions with increasing discharge.

At the reach scale, field measurements made in water years 2008 and 2009 in four study reaches within the Scenic Reach were used to (1) characterize the elevation and geomorphic processes associated with fluvial landforms, (2) build hydraulic geometry relations, (3) examine flow hydraulics over a range of discharges, and (4) examine the types and responses of hydraulic microhabitats to a range of flow magnitudes. Four landform groups were identified and named in order of increasing elevation as the low flood plains, intermediate flood plains, low terraces, and high terraces. The terraces were poorly characterized because the surveys did not extend across the full width of the alluvial valley bottom. The two lowest fluvial landforms are likely active in the modern hydroclimatic regime. The low flood plain is inundated in most years by the annual peak flood and may be "genetic," in the sense that it is constructed of sediments transported by the annual spring flood regime. The discontinuous nature of the low flood plain is likely the result of occasional destruction or erosion by the higher stages of ice-jam-induced floods. The intermediate flood plains were identified in all study reaches and are between 2.4 and $6.7 \mathrm{ft}$ above the stage of the median discharge, indicating they are not inundated by spring storm runoff processes. However, the higher end of the stage range of the intermediate flood plain closely corresponds to the range of local ice-jam elevations surveyed in the study reaches during water year 2008. Thus, the intermediate floodplain may be active on a relatively frequent basis from flooding caused by ice jamming and associated backwater flooding.

Sediment samples obtained in the study reaches indicate that the primary bed material in the active channel ranged in size from coarse silt ( 0.031 to $0.0625 \mathrm{~mm}$ ) to coarse sand ( 0.5 to $1.0 \mathrm{~mm}$ ), and the majority of grain sizes ranged between about 0.2 and $0.5 \mathrm{~mm}$. Grain-size distributions from samples also indicate that the bed of the Niobrara River coarsens and has increasing grain-size variability in the downstream direction, a pattern that likely results from inputs of coarser sediments at tributary junctions, bank erosion, and landslides or other direct hillslope sediment delivery to the channel.

Values of at-a-station hydraulic geometry exponents indicate that the Niobrara River in the study reaches adjusts its geometry to changing discharges primarily through increases in flow depth and velocity. The Crooked study reach had too few measurements, over a relatively narrow range of discharges, to develop statistically meaningful hydraulicgeometry relations. Width $(b)$ exponents at five of the six cross sections were less than 0.06 , and four of the statistical models describing width adjustments lack significance at the 90-percent confidence level. Depth $(f)$ and velocity $(m)$ exponents range in value from 0.17 to 0.60 and 0.29 to 0.84 , respectively. All fitted depth- and velocity-adjustment statistical models were significant at the 90-percent confidence level. The hydraulic geometry relations indicate that the Niobrara River at most locations in the study reaches does not typically accommodate flow increases through changes in channel width. Exponents at one cross section in the Muleshoe study reach ranged from 0.29 to 0.37 indicating that, at least locally, changes in width were also an important channel adjustment mechanism. The more complex hydraulic geometry relations at the one cross section in the Muleshoe study reach are similar to those described further downstream in the BB province, and likely are representative of reaches, or short sections of reaches, in the CRB province where the channel has localized morphologic complexity associated with isolated mid-channel deposition, or variations in bedrock topography.

Hydraulic behavior over the range of flows measured was not consistent among all reaches, but two general modes can be inferred from the calculated parameters at Sunny Brook, Muleshoe, and Rock Barn. At the Sunny Brook and Muleshoe study reaches, average boundary-shear stress remained approximately constant for discharges below $900 \mathrm{ft}^{3} / \mathrm{s}$. Above $900 \mathrm{ft}^{3} / \mathrm{s}$, average boundary shear stress increased by approximately 20 to 30 percent. At the Rock Barn study reach, shear stress showed little to no change in the rate of increase with increasing discharge. Hydraulic resistance was observed to decrease with increasing discharge below $900 \mathrm{ft}^{3} / \mathrm{s}$ at the Sunny Brook, Muleshoe, and Rock Barn study reaches. Above 
$900 \mathrm{ft}^{3} / \mathrm{s}$, resistance increased or stabilized at the Sunny Brook and Muleshoe reaches but continued to decrease at the Rock Barn reach.

The two-mode behavior of shear stress and resistance at the Sunny Brook and Muleshoe reaches indicates that the bed configuration may have changed at a discharge above $900 \mathrm{ft}^{3} / \mathrm{s}$. When plotted over experimental bedform classification diagrams, the values of unit stream power for the range of median grain-size diameters sampled indicate that the Muleshoe and Sunny Brook reaches were on the margin or entirely within the transition to upper flow-regime (plane bed/antidune) bed phases. The Rock Barn study reach did not exhibit the same two-mode hydraulic behavior observed at the Sunny Brook and Muleshoe reaches. It was hypothesized that the difference in hydraulic behavior was related to a combination of physical differences in the Rock Barn reach, such as lower unit stream power, coarser, less well-sorted bed sediment, and the presence of a channel expansion zone downstream. The coincident increase in boundary shear stress above $900 \mathrm{ft}^{3} / \mathrm{s}$ observed at the Sunny Brook and Muleshoe study reaches represents a potential hydraulic threshold above which bedload transport rates were likely to increase markedly.

No consistent bed-adjustment pattern (scour or fill) was identified in the study reaches over the range of flows or over the measurement season. However, as expected, the reaches with substantial coverage of the bed by fine sedimentSunny Brook, Muleshoe, and Rock Barn- exhibited greater bed elevation variability than did the reach with a bedrockdominated bed, Crooked reach.

Analysis of hydraulic microhabitats over the range of discharges measured at the study reaches indicates that some percentage of most habitat niche categories was available for at least one discharge condition, but the majority of hydraulic habitat available was within the intermediate-swift and deep-swift habitat niche categories. Deep-swift conditions dominated nearly all study reaches under all measured discharge conditions. Slight differences in habitat distributions were observed between the study reaches with substantial coverage of the bed by fine sediment-Sunny Brook, Muleshoe, and Rock Barn - and the bedrock-dominated reach, Crooked. At the Crooked reach, the intermediate-swift habitat category dominated the distribution during the lowest measured discharge, and the deep-swift habitat category dominated during the median-quantile discharge. With the exception of the Sunny Brook reach, the deep-swift habitat niche dominated the distribution for all ranges of discharges in the reaches with substantial amounts of sand on the bed.

Although the four study reaches occupy three different hydrogeomorphic segments, the types, relative abundance, and response of hydraulic microhabitat niche distributions to changing discharge conditions generally were similar among all reaches. The types of niches and response of hydraulic habitat distributions to changing discharge conditions in these four reaches were most similar to those calculated for the Sparks gaging station, where the primary habitat adjustment was an increase in flow depth. This similarity in response was not unexpected because three of the four reaches are in the CRB fluvial geomorphic province and most cross sections have similar at-a-station hydraulic geometries. As compared to the Sparks gage, the study reaches all had greater abundance of the deeper habitat categories over the range of discharge frequencies analyzed. At the Rock Barn reach, which is in the BB fluvial geomorphic province, the response of hydraulic microhabitat distribution was virtually identical to those of the other reaches. Several reasons are hypothesized for similar distributions of hydraulic microhabitat niches at each study reach. To fully characterize the hydraulic microhabitat niche types, extents, and response to changing flow conditions in contrasting segments within and between provinces, a more elaborate field study would be necessary that focuses on particular hydrogeomorphic settings representing differing channel morphologic features.

\section{Acknowledgments}

We thank Larry Hutchinson, Richard Holland, and Steven Schainost of the Nebraska Game and Parks Commission for their thoughtful reviews and data-collection assistance throughout this project; the National Park Service for their assistance with field measurements; the Nature Conservancy, U.S. Fish and Wildlife Service, and the landowners at Sunny Brook Camp and Rock Barn Outfitters for the gracious access granted to their property. Reviews and suggestions by Robert Meade and John Stamm greatly improved this report. Daniel Ginting provided valuable statistical advice.

\section{References Cited}

Alexander, J.S., Zelt, R.B., and Schaepe, N.J., 2009, Geomorphic segmentation, hydraulic geometry, and hydraulic microhabitats of the Niobrara River, Nebraska—Methods and initial results: U.S. Geological Survey Scientific Investigations Report 2009-5008, 34 p.

Allred, T.M., and Schmidt, J.C., 1999, Channel narrowing by vertical accretion along the Green River near Green River, Utah: Geological Society of America Bulletin, v. 111, p. $1,757-1,772$.

Athaullah, M., 1968, Prediction of bedforms in erodible channels: Fort Collins, Colo., Colorado State University, Ph.D. thesis, $144 \mathrm{p}$.

Bagnold, R.A., 1977, Bed load transport in natural rivers: Water Resources Research, v. 13, p. 303-312.

Bentall, Ray, and Shaffer, F.B., 1979, Availability and use of water in Nebraska, 1975: Lincoln, University of Nebraska, Conservation Survey Division, Nebraska Water Survey Paper 48, 121 p. 
Boucher, E., Begin, Y., and Arseneault, D., 2009, Impacts of recurring ice jams on channel geometry and geomorphology in a small high-boreal watershed: Geomorphology, v. 108, p. 273-281.

Bramblett, R.G., and White, R.G., 2001, Habitat use and movements of pallid and shovelnose sturgeon in the Yellowstone and Missouri Rivers in Montana and North Dakota: Transactions of the American Fisheries Society, v. 130, p. $1,006-1,025$.

Bridge, J.S., 2003, Rivers and flood plains-Forms, processes, and sedimentary record: Oxford, England, Blackwell Publishing, $491 \mathrm{p}$.

Bristow, C.S., Skelly, R.L., and Etheridge, F.G., 1999, Crevasse splays from the rapidly aggrading, sand-bed, braided Niobrara River, Nebraska-Effect of base-level rise: Sedimentology, v. 46, p. 1,029-1,047.

Buchanan, J.P., 1981, Channel morphology and sedimentary facies of the Niobrara River, north-central Nebraska: Fort Collins, Colo., Colorado State University, M.S. thesis, $126 \mathrm{p}$.

Bull, W.B., 1979, Threshold of critical power in streams: Geological Society of America Bulletin, v. 90, p. 453-464.

Burchett, R.R., comp., 1986, Geologic bedrock map of Nebraska: Lincoln, Nebraska Geological Survey, scale $1: 1,000,000$.

Colby, B.R., 1964, Scour and fill in sand-bed streams: U.S. Geological Survey Professional Paper 462-D, 32 p.

Colby, B.R., and Hembree, C.H., 1955, Computations of total sediment discharge, Niobrara River near Cody, Nebraska: U.S. Geological Survey Water-Supply Paper 1357, 187 p.

Colby, B.R., Matejka, D.Q., and Hubbell, D.W., 1953, Investigations of fluvial sediments of the Niobrara River near Valentine, Nebraska: U.S. Geological Survey Circular 205, $57 \mathrm{p}$.

Cole, J.M., 1996, Aggradation, degradation, and levels of heterogeneity of the braided Niobrara River, Nebraska: Fort Collins, Colo., Colorado State University, M.S. thesis, 83 p.

Dietsch, B.J., 2007, Water-quality and fish-community data for the Niobrara National Scenic River, Nebraska: U.S. Geological Survey Fact Sheet 2007-3098, 6 p.

Doyle, M.W., Stanley, E.H., Strayer, D.L., Jacobson, R.B., and Schmidt, J.C., 2005, Effective discharge analysis of ecological processes in streams: Water Resources Research, v. 41, $16 \mathrm{p}$.
Dugan, J.T., and Zelt, R.B., 2000, Simulation and analysis of soil-water conditions in the Great Plains and adjacent areas, Central United States, 1951-80: U.S. Geological Survey Water Supply Paper 2427, $81 \mathrm{p}$.

Edwards, T.K., and Glysson, G.D., 1999, Field methods for measurement of fluvial sediment: U.S. Geological Survey Techniques of Water Resources Investigations, book 3, chap. C2, 89 p.

Etheridge, F.G., Skelly, R.L., and Bristow, C.S., 1999, Avulsion and crevassing in the sandy, braided Niobrara River-Complex response to base-level rise and aggradation: Special Publication of the International Association of Sedimentology, v. 28, p. 179-191.

Everitt, B.S., and Dunn, G, 1991, Applied multivariate data analysis: London, Edward Arnold, 342 p.

Fisher, R.A., 1949, The design of experiments: Oliver and Boyd, Edinburgh, 250 p.

Folk, R.L., 1974, Petrology of sedimentary rocks: Hemphill Publishing Co., Austin, Tex., 182 p.

Frissell, C.A., Liss, W.J., Warren, C.E., and Hurley, M.D., 1986, A hierarchical framework for stream habitat classification-Viewing streams in a watershed context: Environmental Management, v. 10, p. 199-214.

Ginting, Daniel, and Zelt, R.B., 2008, Temporal differences in flow depth and velocity distributions and hydraulic microhabitats near bridges of the lower Platte River, Nebraska, 1934-2006: U.S. Geological Survey Scientific Investigations Report 2008-5054, 99 p.

Grams, P.E., and Schmidt, J.C., 2002, Streamflow regulation and multi-level flood plain formation-Channel narrowing on the aggrading Green River in eastern Uinta Mountains, Colorado and Utah: Geomorphology, v. 44, p. 337-360.

Gutzmer, M.P., King, J.W., and Overhue, D.P., 1996, Environmental impacts in the vicinity of Spencer hydropower dam during sluicing activities in the Niobrara River, Nebraska: Transactions of the Nebraska Academy of Sciences, v. 23, p. $1-8$.

Guy, H.P., 1969, Laboratory theory and methods for sediment analysis: U.S. Geological Survey Techniques of WaterResources Investigations book 5, chap. C1, 58 p.

Hearty, P.J., 1978, The biogeography and geomorphology of the Niobrara River valley near Valentine, Nebraska: Omaha, University of Nebraska, M.S. thesis, 108 p. 
Helsel, D.R., and Hirsch, R.M., 2002, Statistical methods in water resources: U.S. Geological Survey Techniques of Water-Resources Investigations, book 4, chap. A3, 523 p.

Hey, R.D., and Thorne, C.R., 1986, Stable channels with mobile gravel beds: Journal of Hydraulic Engineering, v. 112, p. 671-689.

Howard, A.D., 1987, Modeling fluvial systems-Rock, gravel, and sand bed channels, in Richards, K.S., ed., River Channels, Oxford, Basil Blackwell, p. 69-94.

Howard, A.D., 1998, Long profile development of bedrock channels - Interaction of weathering, mass wasting, bed erosion, and sediment transport: Geophysical Monograph, v. 107 , p. 297-319.

Huang, H.Q., and Nanson, G.C., 2000, Hydraulic geometry and maximum flow efficiency as products of the principle of least action: Earth Surface Processes and Landforms, v. 25, p. $1-16$.

Istanbullouglu, E., 2009, Hydrological analysis of the Niobrara River: final report to the Nebraska Game and Parks Commission, University of Nebraska-Lincoln, 71 p.

Johnsgard, P.A., 2001, The nature of Nebraska - Ecology and biodiversity: Lincoln, Nebr., University of Nebraska Press, $402 \mathrm{p}$.

Johnsgard, P.A., 2007, The Niobrara - A river running through time: Lincoln, Nebr., University of Nebraska Press, $352 \mathrm{p}$.

Johnson, W.C., 1994, Woodland expansions in the Platte River, Nebraska-Patterns and causes: Ecological Monographs, v. 64, p. 45-84.

Junk, W.J., Bayley, P.B., and Sparks, R.E., 1989, The flood pulse concept in river-flood plain systems: Canadian Special Publication of Fisheries and Aquatic Science., v. 106, p. 110-127.

Knighton, A.D., 1974, Variation in width-discharge relation and some implications for hydraulic geometry: Geological Society of America Bulletin, v. 85, p. 1,069-1,076.

Knighton, A.D., 1998, Fluvial forms and processes: Chichester, England, John Wiley and Sons, 383 p.

Knighton, A.D., and Nanson, G.C., 1993, Anastomosis and the continuum of channel pattern: Earth Surface Processes and Landforms, v. 18, p. 613-625.

Kochel, R.C., and Baker, V.R., 1988, Paleoflood analysis using slackwater deposits, in Baker, V.R., Kochel, R.C., and Patton, P.C., eds., Flood geomorphology: New York, Wiley, p. 279-300.
Kondolf, G.M., 1995, Geomorphological stream classification in aquatic habitat restoration-Uses and limitations: Aquatic Conservation: Marine and Freshwater Ecosystems, v. 5, p. 127-141.

Kondolf, G.M., and Downs, P.W., 1996, Catchment approach to planning channel restoration, in Brookes, A., and Shields, F.D., Jr., River channel restoration-Guiding principles for sustainable projects: Chichester, England, John Wiley and Sons, p. 129-148.

Leeder, M., 1999, Sedimentology and sedimentary basinsFrom turbulence to tectonics: Oxford, England, Blackwell Publishing, 592 p.

Leopold, L.B., and Maddock, Thomas, Jr., 1953, The hydraulic geometry of stream channels and some physiographic implications: U.S. Geological Survey Professional Paper $252,57 \mathrm{p}$.

Leopold, L.B., and Wolman, M.G., 1957, River channel patterns-Braided, meandering, and straight: U.S. Geological Survey Professional Paper 282-B, 85 p.

Leopold, L.B., Wolman, M.G., and Miller, J.P., 1964, Fluvial processes in geomorphology: San Francisco, Calif., Freeman, $522 \mathrm{p}$.

Maddock, Ian, 1999, The importance of physical habitat assessment for evaluating river health: Freshwater Biology, v. 41, p. 373-391.

McKenny, Rose, 1997, Formation and maintenance of hydraulic habitat units in streams of the Ozark Plateaus: State College, Penn. State University, unpublished Ph.D. dissertation, $340 \mathrm{p}$.

Missouri River Basin Inter-Agency Committee, 1967, Flood damage and related problems and needs - subbasin 5Platte and Niobrara: report prepared by Task Force on Flood Control and Prevention for Missouri Basin Interagency Committee, $45 \mathrm{p}$.

Moody, J.A., and Meade, R.H., 2008, Terrace aggradation during the 1978 flood on Powder River, Montana: Geomorphology, v. 99, p. 387-403.

Nadler, C.T., and Schumm, S.A., 1981, Metamorphosis of South Platte and Arkansas Rivers, eastern Colorado: Physical Geography, v. 2, p. 95-115.

Nanson, G.C., 1986, Episodes of vertical accretion and catastrophic stripping - A mode of disequilibrium flood plain development: Geological Society of America Bulletin, v. 97, p. 1,467-1,475.

Nanson, G.C., and J.C., Croke, 1992, A genetic classification of flood plains: Geomorphology, v. 4, p. 459-486. 
Nebraska Department of Natural Resources, 2004, Nebraska Digital Orthophoto Quadrangles (DOQQ)-1999: Lincoln, Nebraska, Department of Natural Resources work-share agreement with U.S. Geological Survey.

Nebraska Department of Natural Resources, 2007, 2008 Annual evaluation of availability of hydrologically connected water supplies, determination of fully appropriatedFinal report: Lincoln, Nebraska Department of Natural Resources, $145 \mathrm{p}$.

Nebraska Game and Parks Commission, 1980, A study of the effects of Spencer hydro flushing on water quality, fishes, and insect fauna in the Niobrara River: technical report, Nebraska Game and Parks Commission-Fisheries Division Research, $41 \mathrm{p}$.

Park, C.C., 1977, World-wide variations in hydraulic geometry exponents of stream channels-An analysis and some observations: Journal of Hydrology, v. 33, p. 133-146.

Parker, Gary, Wilcock, P.R., Paola, Chris, Dietrich, W.E., and Pitlick, John, 2007, Physical basis for quasi-universal relations describing bankfull hydraulic geometry of singlethread gravel bed rivers: Journal of Geophysical Research, v. $112,21 \mathrm{p}$.

Pazzaglia, F.J., Gardner, T.W., and Merritts, D.J., 1998, Bedrock fluvial incision and longitudinal profile development over geologic time scales determined by fluvial terraces: Geophysical Monograph, v. 107, p. 207-235.

Pederson, J.L., Anders, M.D., Rittenhour, T.M., Sharp, W.D., Gosse, J.C., and Karlstrom, K.E., 2006, Using fill terraces to understand incision rates and evolution of the Colorado River in eastern Grand Canyon, Arizona: Journal of Geophysical Research v. 111, F02003.

Peters, E.J., and Holland, R.S., 1992, Shallow-water fish community abundance and habitat use in the lower Platte River, Nebraska: University of Nebraska-Lincoln, Department of Forestry, Fisheries and Wildlife, Journal Series No. 9109.

Poff, N.L., Allen, J.D., Bain, M.B., Karr, J.R., Prestegaard, K.L., Richter, Brian, Sparks, R.E, and Stromberg, J.C., 1997, The natural flow regime-A new paradigm for riverine conservation and restoration: Bioscience, v. 47, p. 769-784.

Poff, N.L., and Ward, J.V., 1990, The physical habitat template of lotic systems-Recovery in the context of historical pattern of spatio-temporal heterogeneity: Environmental Management, v. 14, p. 629-646.
Power, M.E., Sun, Adrian, Parker, Gary, Dietrich, W.E., and Wooton, J.T., 1995, Hydraulic food chain models-An approach to the study of food-web dynamics in large rivers: Bioscience, v. 45, p. 159-167.

Randle, T., 2002, Niobrara River bank erosion assessment: technical report, Denver, Colo., Bureau of Reclamation Technical Service Center, 15 p.

Rantz, S.E., and others, 1982, Measurement and computation of streamflow: U.S. Geological Survey Water-Supply Paper 2175 , v. 1, 284 p.

Roeder, J.A., 2004, The One Hundred and Second Congress and the Niobrara Scenic River-Old arguments, new compromises: Nebraska History, v. 85, p. 116-127.

Richards, K.S., 1977, Channel and flow geometry: Progress in Physical Geography, v. 1, p. 65-102.

Shaffer, F.B., 1975, History of irrigation and characteristics of streamflow in northern Nebraska: U.S. Geological Survey Open-File Report 75-01, 114 p.

Shafroth, P.B., Wilcox, A.C., Lytle, D.A., Hickey, J.T., Anderson, D.C., Beauchamp, V.B., Hautzinger, A., McMullen, L.E., and Warner, A., 2010, Ecosytem effects of environmental flows - Modeling and experimental floods in a dryland river: Freshwater Biology, v. 55, p. 68-85.

Simons, D.B., and Richardson, E.V., 1966, Resistance to flow in alluvial channels: U.S. Geological Survey Professional Paper 422-J, 61 p.

Skelly, R.L., 1998, Evolution and facies architecture of modern braided river deposits-The Niobrara River, northeast Nebraska: Fort Collins, Colo., Colorado State University, M.S. thesis, 239 p.

Smith, D.G., and Putnam, P.E., 1980, Anastomosed river deposits-Modern and ancient examples in Alberta, Canada: Canadian Journal of Earth Sciences, v. 17, p. $1,396-1,406$.

Soenksen, P.J., Miller, L.D., Sharpe, J.B., and Watton, J.R., 1999, Peak-flow frequency relations and evaluation of the peak-flow gaging network in Nebraska: U.S. Geological Survey Water-Resources Investigations Report 99-4032, $47 \mathrm{p}$.

Soller, D.R., and Reheis, M.C., 2003, Surficial materials in the conterminous United States: U. S. Geological Survey OpenFile Report 2003-275, map, scale 1:5,000,000. 
Stalnaker, C.B., Bovee, K.D., and Waddle, T.J., 1996, Importance of the temporal aspects of habitat hydraulics to fish population studies: Regulated Rivers-Research and Management, v. 12, p. 145-153.

Swinehart, J.B., Souders, V.L., DeGraw, H.M., and Diffendal, R.F., 1985, Cenozoic paleogeography of western Nebraska, in Flores, R.M, and Kaplan, S.S., eds., Cenozoic paleogeography of the west-central United States: Society of Economic Paleontologists and Minerologists, Rocky Mountain Section, Rocky Mountain Paleogeography Symposium 3, p. 209-229.

TIBCO Software Inc., 2008, TIBCO Spotfire S+ 8.1—Guide to Statistics, v. 1 and v. 2, [variously paged].

Tukey, J.W., 1953, The problem of multiple comparisons: unpublished manuscript, in The Collected Works of John W. Tukey VIII. Multiple Comparisons-1948-1983: New York, Chapman and Hall, p. 1-300.

U.S. Department of Agriculture, Farm Service Agency, Aerial Photography Field Office, 2004, FSA Digital Orthophoto 2003 - UTM - Index for the State of Nebraska: Salt Lake City, Utah.

U.S. Department of Agriculture-Natural Resources Conservation Service, 2008 Watershed boundary data set for HUC 101500, Nebraska: Natural Resources Conservation Service, http://datagateway.nrcs.usda.gov, accessed online October 22, 2008.

University of Nebraska-Lincoln, Conservation and Survey Division, 1986, The ground water atlas of Nebraska: Lincoln, University of Nebraska, Conservation and Survey Division, Resource Atlas No. 4, 32 p.
Van Steeter, M.V., and Pitlick, J., 1998, Geomorphology and endangered fish habitats of the upper Colorado River-1. Historic changes in streamflow, sediment load, and channel morphology: Water Resources Research, v. 34, p. 287-302.

Voorhies, M.R., 1987, Late Cenozoic stratigraphy and geomorphology, Fort Niobrara, Nebraska, in Geological Society of America Centennial Field Guide: Boulder, Colo., Geological Society of America, North-Central Section, v. 13, p. 1-6.

Wanner, G.A., Pegg, M.A., Shuman, D.A., and Klumb, R.A., 2009, Niobrara River fish community downstream of Spencer Dam, Nebraska — 2008 progress report: Pierre, S. Dak., U.S. Fish and Wildlife Service, submitted to Nebraska Game and Parks Commission, 58 p.

Wildhaber, M.L., Delonay, A.J., Papoulias, D.M., Galat, D.L., Jacobson, R.B., Simpkins, D.G., Braaten, P.J., Korschgen, C.E., and Mac, M.J., 2007, A conceptual life-history model for pallid and shovelnose sturgeon: U.S. Geological Survey Circular 1315, 18 p.

Williams, G.P., 1978, The case of the shrinking channels-The North Platte and Platte Rivers in Nebraska: U.S. Geological Survey Circular 781, 48 p.

Wolman, M.G., and Gerson, R., 1978, Relative scales of time and effectiveness of climate in watershed geomorphology: Earth Surface Processes and Landforms, v. 3, p. 189-208.

Yang, C.T., 1973, Incipient motion and sediment transport: Journal of the Hydraulics Division, American Society of Civil Engineers, v. 99, p. 1,679-1,704.

Publishing support provided by:

Rolla and Denver Publishing Service Centers

For more information concerning this publication, contact:

Director, USGS Nebraska Water Science Center

5231 South 19th Street

Lincoln, NE 68512

(402) 328-4100 
Back cover. Top: section of Niobrara River showing example of braided bottoms fluvial geomorphic province. Photograph by Bill Hansen, National Park Service.

Center: section of Niobrara River showing example of canyons and restricted bottoms fluvial geomorphic province. Photograph by Ron Zelt, U.S. Geological Survey.

Bottom: section of Niobrara River showing example of meandering bottoms fluvial geomorphic province.

Photograph by Jason Alexander, U.S. Geological Survey. 


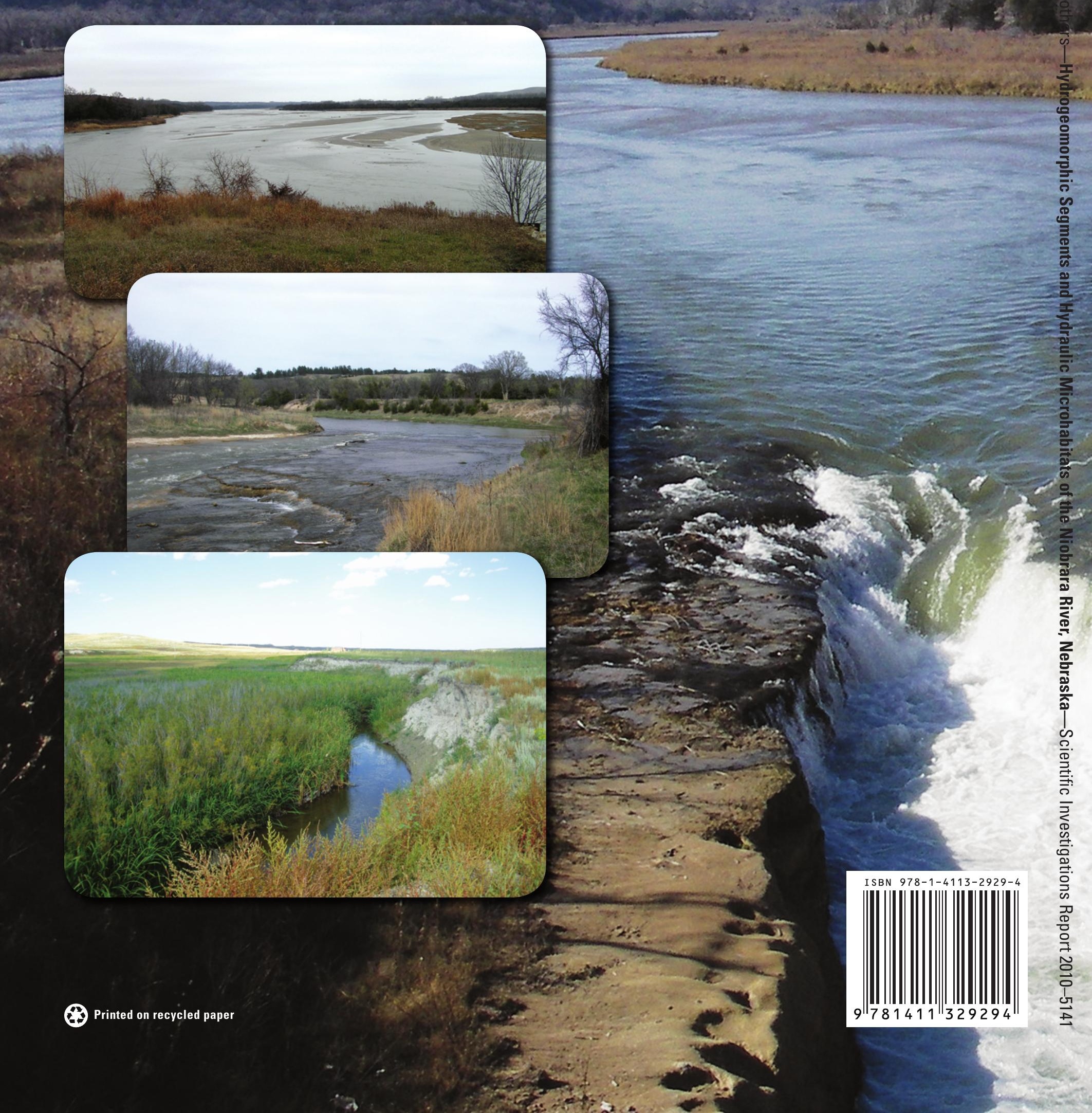

